UNIVERSIDADE ESTADUAL PAULISTA “JÚLIO DE MESQUITA FILHO” FACULDADE DE CIÊNCIAS AGRONÔMICAS CAMPUS DE BOTUCATU

\title{
SELETIVIDADE DE HERBICIDAS À CULTURA DA MANDIOCA
}

MAGNO LUIZ DE ABREU

Dissertação apresentada à Faculdade de Ciências Agronômicas da UNESP Campus de Botucatu, para obtenção do título de Mestre em Agronomia Agricultura.

BOTUCATU - SP

Fevereiro-2010 


\title{
UNIVERSIDADE ESTADUAL PAULISTA “JÚLIO DE MESQUITA FILHO” FACULDADE DE CIÊNCIAS AGRONÔMICAS CAMPUS DE BOTUCATU
}

\section{SELETIVIDADE DE HERBICIDAS À CULTURA DA MANDIOCA}

\author{
MAGNO LUIZ DE ABREU \\ Engenheiro Agrônomo
}

Orientador: Prof. Dr. SILVIO JOSÉ BICUDO

Co-Orientador: Prof. Dr. DAGOBERTO MARTINS

Dissertação apresentada à Faculdade de Ciências Agronômicas da UNESP - Campus de Botucatu, para obtenção do título de Mestre em Agronomia -Agricultura.

\footnotetext{
BOTUCATU - SP
}

Janeiro - 2010 
FICHA CATALOGRÁFICA ELABORADA PELA SEÇÃO TÉCNICA DE AOUISIĈ̃̃ E TRATAMENTO DA INFORMAÇÃO - SERVIÇO TÉCNICO DE BIBLIOTECA E DOCUMENTAÇÃO UNESP - FCA LAGEADO - BOTUCATU (SP)

Abreu, Magno Luiz de, 1983-

A162s Seletividade de herbicidas à cultura da mandioca / Magno Luiz de Abreu. - Botucatu, [s.n.], 2010.

vi, 65 f.: il., color., grafs., tabs.

Dissertação (Mestrado)-Universidade Estadual Paulista, Faculdade de Ciências Agronômicas, Botucatu, 2010

Orientador: Silvio José Bicudo

Co-orientador: Dagoberto Martins

Inclui bibliografia

1. Manihot esculenta. 2. Fitotoxicidade. 3. Moléculas de herbicidas. I. Bicudo, Silvio José.II. Martins, Dagoberto. III. Universidade Estadual Paulista "Júlio de Mesquita Filho " (Campus de Botucatu). Faculdade de Ciências Agronômicas. VI. Título. 


\section{UNIVERSIDADE ESTADUAL PAULISTA "JÚLIO DE MESQUITA FILHO" FACULDADE DE CIÊNCIAS AGRONÔMICAS \\ CAMPUS DE BOTUCATU}

\section{CERTIFICADO DE APROVAÇ̃̃o}

TITULO: "SELETIVIDADE DE HERBICIDAS À CULTURA DA MANDIOCA"

ALUNO: MAGNO LUIZ DE ABREU

ORIENTADOR: PROF. DR. SILVIO JOSÉ BICUDO

CO-ORIENTADOR: PROF. DR. DAGOBERTO MARTINS

Aprovado pela Comissão Examinadora
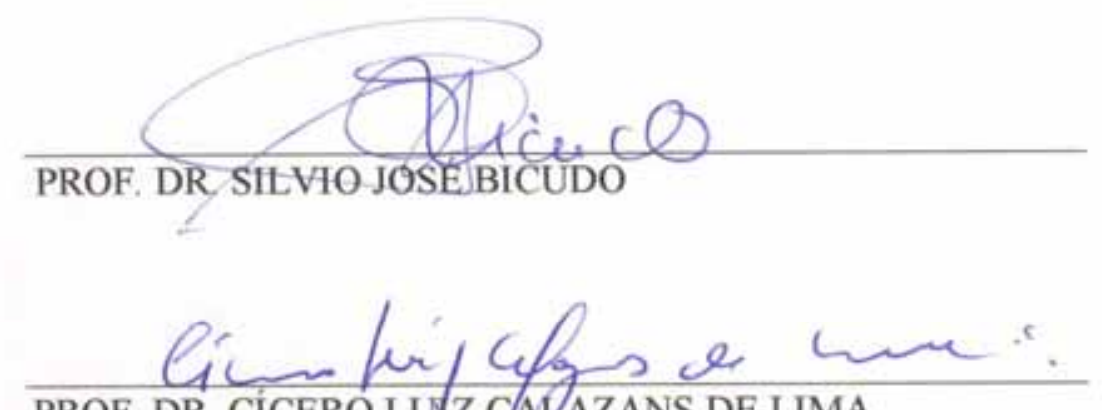

PROF. DR. CICERO LUIZ CAYAZANS DE LIMA

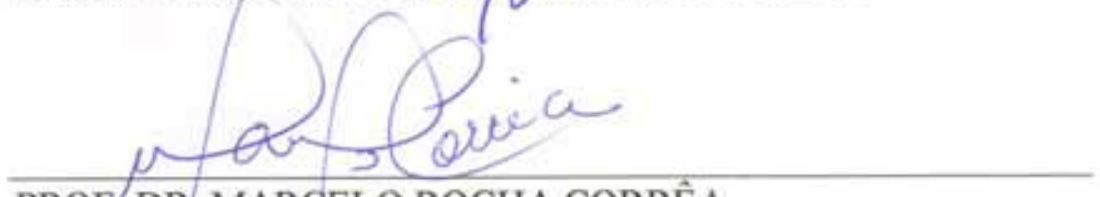

PROF. DR/ MARCELO ROCHA CORREAA

Data da Realização: 05 de fevereiro de 2010. 


\section{BIOGRAFIA DO AUTOR}

Magno Luiz de Abreu, filho de João Deodato de Abreu e Josefa Zélia da Silva Abreu, nasceu na cidade de Arapiraca, Estado de Alagoas em 08 de julho de 1983.

Foi estagiário do programa de melhoramento genético da cana-de-açúcar de Alagoas, de 2004 a 2006, Monitor das disciplinas de forragens e construções rurais, de 2006 a 2007 e aluno de Iniciação Científica no departamento de Agrometeorologia, de 2007 a 2008.

Diplomou-se em Agronomia pela Universidade Federal de Alagoas, em 2008.

Em Agosto de 2008 iniciou o curso de Mestrado em Agronomia, na Faculdade de Ciências Agronômicas, UNESP, Campus de Botucatu. 
Aos meus pais João Deodato de Abreu e Josefa Zélia S. Abreu

Aos meus irmãos Rubenilton (In memorian), Messias e Juliana A minha noiva Lilian Guimarães de Favare.

DEDICO

Ao Prof. Dr. Silvio José Bicudo À eficiente equipe de trabalho que tanto colaborou. 


\section{AGRADECIMENTOS}

A Deus, por tamanha realização.

A Faculdade de Ciências Agronômicas - UNESP, pela oportunidade oferecida para realização deste curso.

A coordenação e colegiado do curso de Pós-Graduação em Agricultura por todo apoio.

Ao CNPq, pela concessão de bolsa de estudo.

Ao Prof. Dr. Silvio José Bicudo pela orientação, amizade e principalmente por formar não só um profissional e sim um homem, na qual espelhará seu futuro na honestidade e simplicidade vista em sua trajetória.

Ao Professor Dagoberto Martins pelas orientações e apoio constantes na realização do projeto.

Ao Professor Iêdo Teodoro que tanto me apóia.

Aos meus pais por tamanho amor e compreensão durante toda a minha vida.

Ao meu irmão Rubenilton Luis de Abreu (in memorian), por tudo que fizeste por mim em vida, nunca esquecerei, nem por um minuto o teu orgulho ao falar meu nome.

Aos funcionários da biblioteca "Paulo de Carvalho Mattos" e da Seção de Pós-Graduação, pelo eficiente atendimento.

A minha noiva Lílian pelo companheirismo e amor.

Aos funcionários do Departamento de Agricultura e Melhoramento Vegetal e da Fazenda Experimental São Manuel pela amizade, apoio e dedicação na condução deste experimento.

Aos amigos Rômulo, Elizeu e Gabriel pela amizade e apoio em todos os momentos.

A eficiente equipe de pesquisa composta por: Rafael, Elizeu, Simério, Eduardo e Felipe. 
Aos estagiários Gabriel, Giovana, Caio, Luiz Fernando e Bruno.

A todos que contribuíram de alguma forma para realização deste trabalho, meus agradecimentos. 


\section{SUMÁRIO}

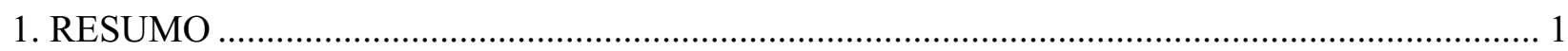

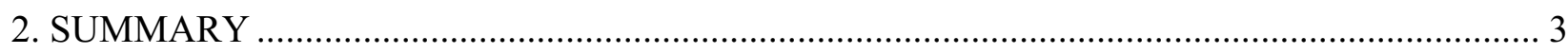

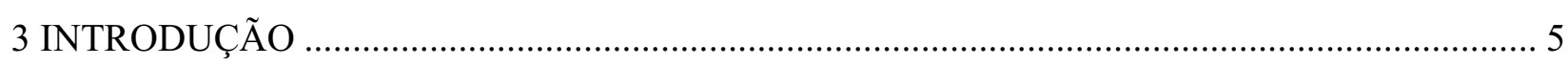

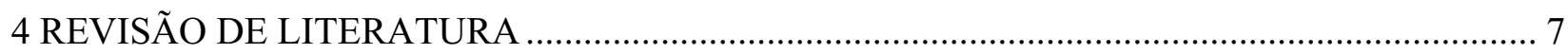

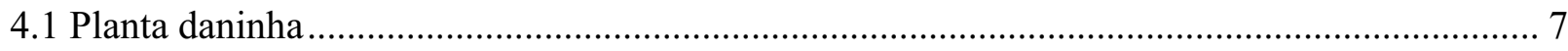

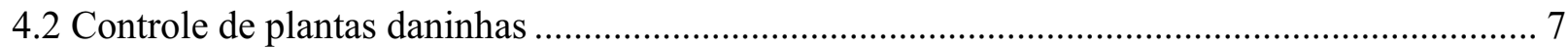

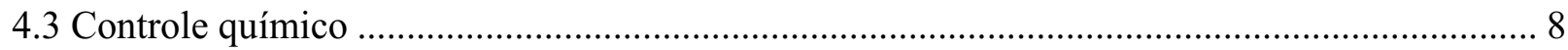

4.4 Eficiência e seletividade dos herbicidas na cultura da mandioca ............................................. 9

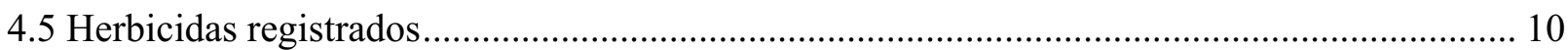

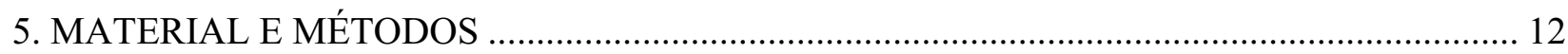

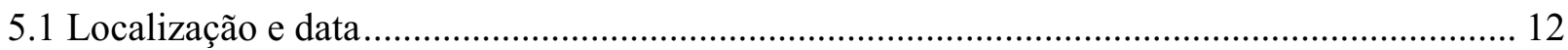

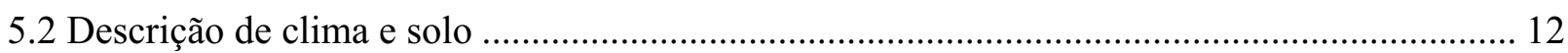

5.3 Idade das plantas e manivas utilizadas no plantio ................................................................ 15

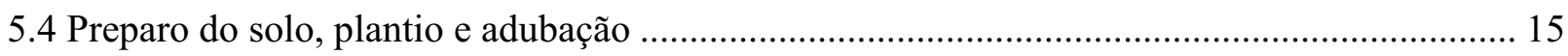

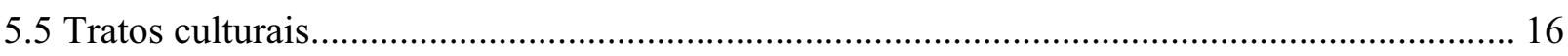

5.6 Delineamento Experimental e cultivares utilizadas............................................................. 16

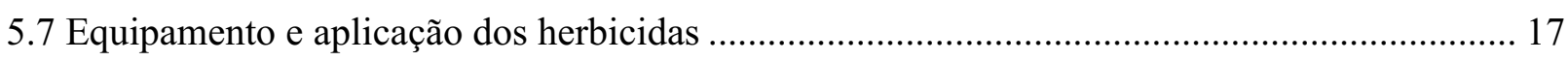

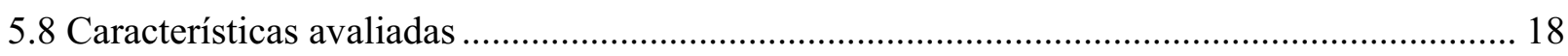

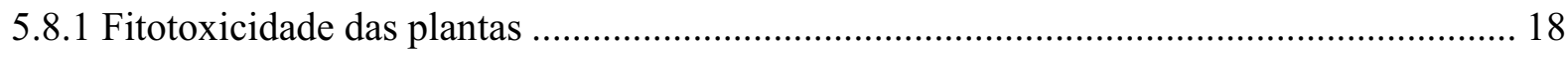

5.8.2 Altura do dossel, altura primeira ramificação e diâmetro do caule das plantas ................. 19

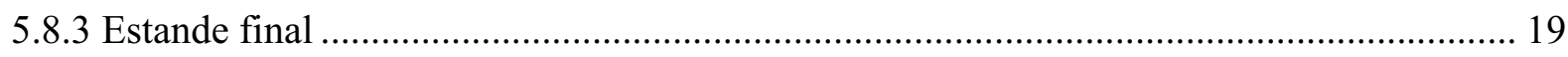

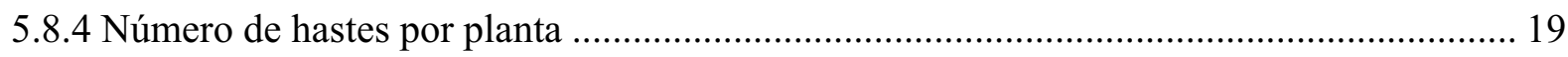

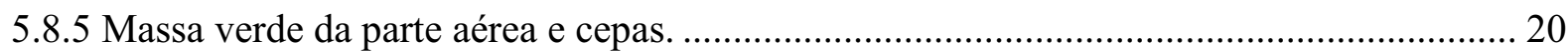

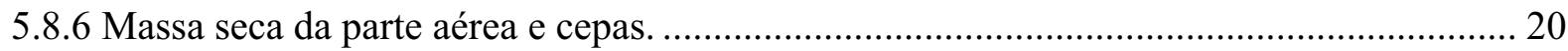

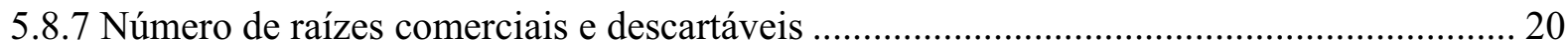

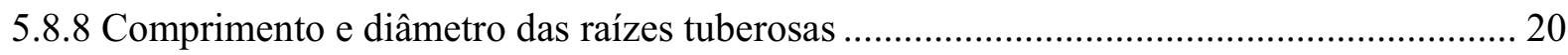

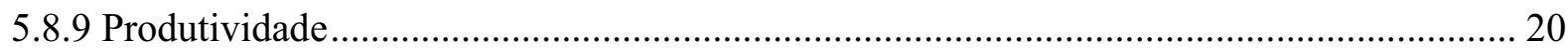

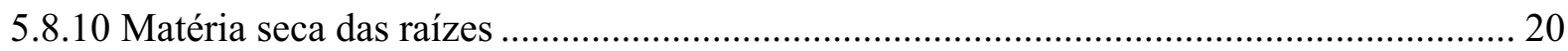

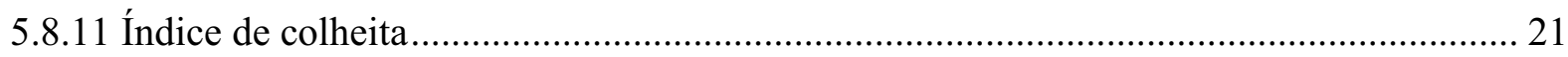

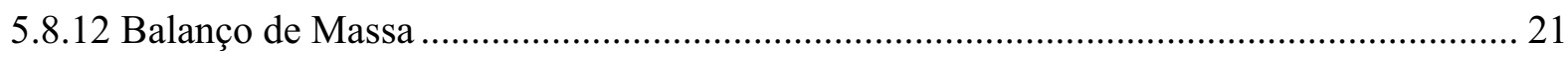




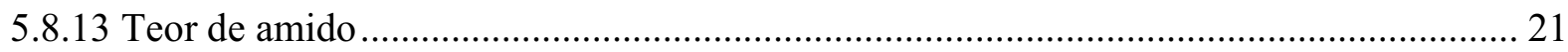

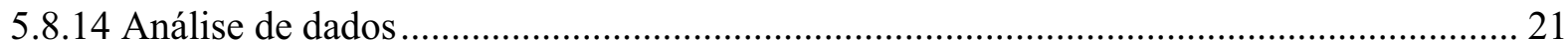

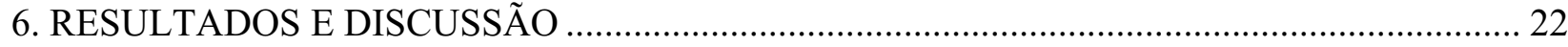

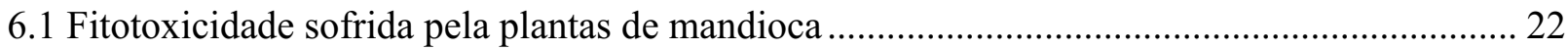

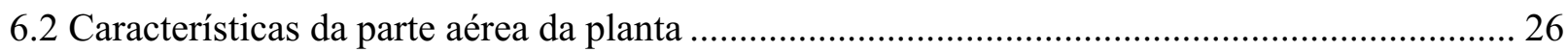

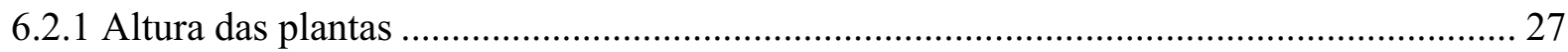

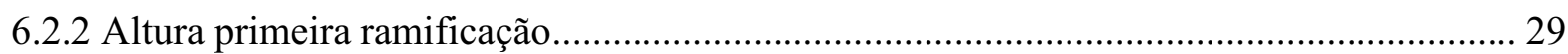

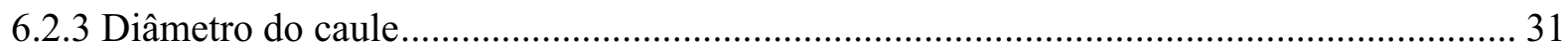

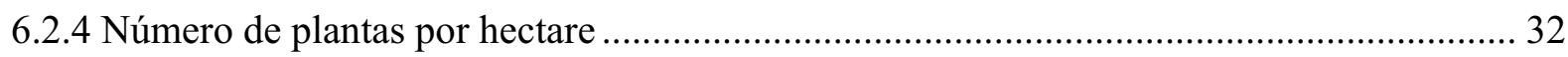

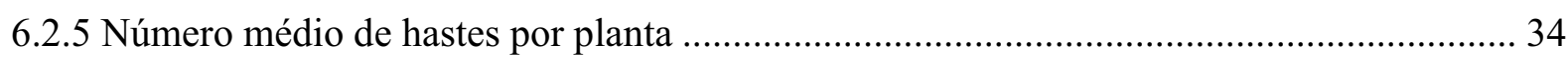

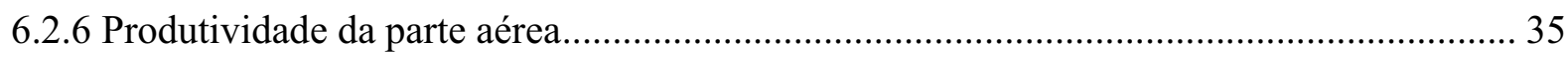

6.2.7 Produtividade de matéria seca da parte aérea ............................................................... 37

6.2.8. Porcentagem de matéria seca da parte aérea ..................................................................... 39

6.3 Características da parte subterrânea da planta ............................................................................ 39

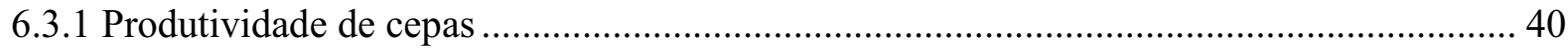

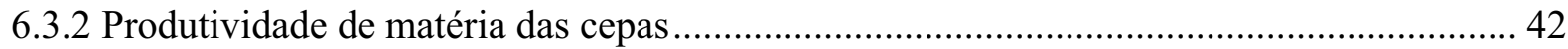

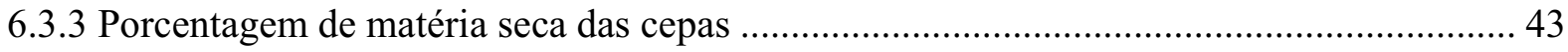

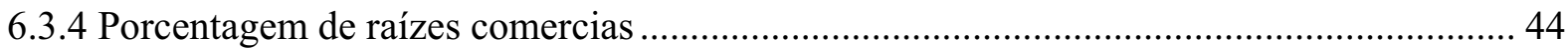

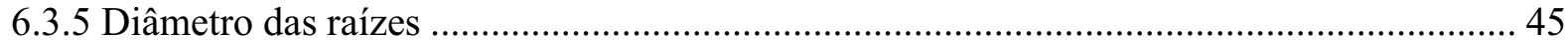

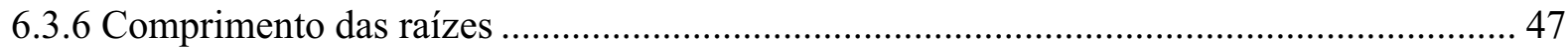

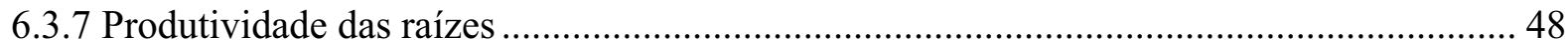

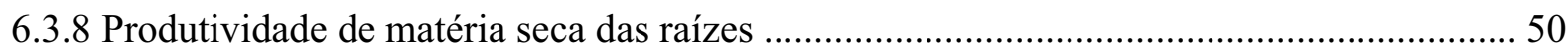

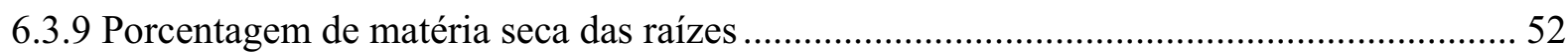

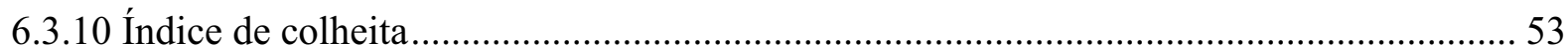

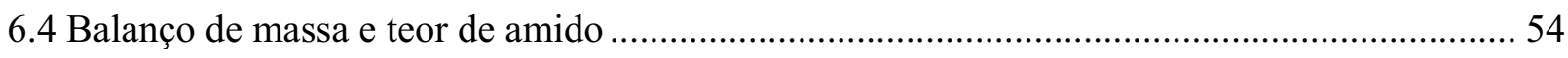

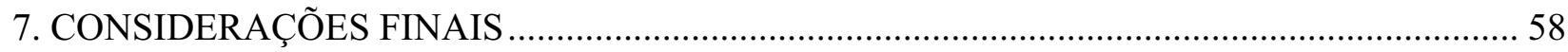

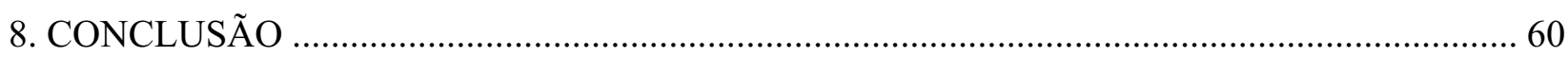

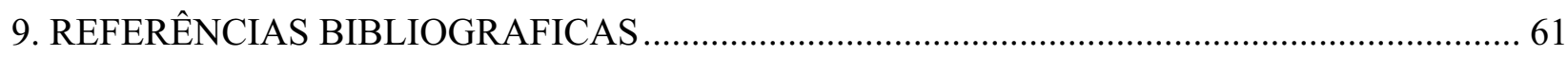




\section{LISTA DE FIGURAS}

Figura 1. Dados climatológicos do período de Dezembro de 2008 a Setembro de 2009 em São Manuel (SP). 13

Figura 2. Dados climatológicos do período de Dezembro de 2008 a Setembro de 2009 em Botucatu (SP)

Figura 4. Aplicação dos herbicidas na área Experimental. 18

Figura 5. Comparação de uma planta com injuria causada pela aplicação do herbicida com outra planta sem injuria na Fazenda Experimental São Manuel em São Manuel -SP, na variedade IAC14, avaliadas aos 19 dias após a emergência das plantas de mandioca... 19

Figura 6. Porcentagem de raízes comerciais e descartáveis por hectare das variedades IAC14 e IAC7560-70, em função das moléculas de herbicidas aplicadas em pré e pós-emergência na Fazenda Experimental São Manuel em São Manuel-SP. 44

Figura 7. Porcentagem de raízes comerciais e descartáveis por hectare das variedades IAC14 e IAC7560-70, em função das moléculas de herbicidas aplicadas em pré e pós-emergência na Fazenda Experimental Lageado em Botucatu-SP. 45 


\section{LISTA DE TABELAS}

Tabela 1. Herbicidas registrados atualmente para uso na cultura da mandioca, com seus respectivos métodos de aplicação e dosagens recomendadas, Botucatu-SP, 2010. 11

Tabela 2. Resultados da análise química do solo na profundidade 0-20 cm, amostrado antes da instalação do experimento, Fazenda Experimental São Manuel em São Manuel - SP, 2010. 14 Tabela 3. Resultados da análise química do solo na profundidade 0-20 cm, amostrado antes da instalação do experimento na Fazenda Experimental Lageado em Botucatu - SP, 2010. 14 Tabela 4. Resultados da análise química de micronutrientes do solo na profundidade $0-20 \mathrm{~cm}$, amostrado antes da instalação do experimento, Fazenda Experimental São Manuel em São Manuel SP, 2010. 14

Tabela 5. Resultados da análise química de micronutrientes do solo na profundidade 0-20 cm, amostrado antes da instalação do experimento, Fazenda Experimental Lageado em Botucatu - SP, 2010 14

Tabela 6. Resultado da análise física do solo na profundidade de $0-20 \mathrm{~cm}$, amostrados antes da instalação do experimento, Fazenda Experimental São Manuel em São Manuel - SP, 2010. 15

Tabela 7. Resultado da análise física do solo na profundidade de $0-20 \mathrm{~cm}$, amostrados antes da instalação do experimento, Fazenda Experimental Lageado em Botucatu - SP, 2010. 15

Tabela 8. Descrição dos tratamentos aplicados. 17

Tabela 9. Fitotoxicidade de herbicidas aplicados em pré e pós-emergência na cultura da mandioca nas variedades IAC14 e IAC576-70 em diferentes períodos de avaliação na Fazenda Experimental São Manuel em São Manuel-SP.....

Tabela 10. Fitotoxicidade de herbicidas aplicados em pré e pós-emergência na cultura da mandioca nas variedades IAC14 e IAC576-70 em diferentes períodos de avaliação na Fazenda Experimental Lageado em Botucatu-SP.

Tabela 11. Resumo da análise de variância com valores de F calculados para as causas de variação e sua interação e médias para as características da parte aérea da planta, altura das plantas (cm) (AP), altura da primeira ramificação $(\mathrm{cm})(\mathrm{AR})$, diâmetro do caule $(\mathrm{cm})(\mathrm{DC})$, número de plantas por hectare $(\mathrm{P})$, número de hastes médio por planta $(\mathrm{H})$, produtividade de parte aérea da planta $\left(\mathrm{t} \mathrm{ha}^{-1}\right)$ (PA), produtividade da matéria seca da parte aérea $\left(\mathrm{t} \mathrm{ha}^{-1}\right)$ (MS PA), porcentagem de matéria seca da parte aérea (MS PA), na Fazenda Experimental São Manuel, São Manuel - SP, 2009. 26 
Tabela 12. Resumo da análise de variância com valores de F calculados para as causas de variação e sua interação e médias para as características da parte aérea da planta altura das plantas em $(\mathrm{cm})$ (AP), altura da primeira ramificação em $(\mathrm{cm})(\mathrm{AR})$, diâmetro do caule em $(\mathrm{cm})(\mathrm{DC})$, número de plantas por hectare $(\mathrm{P})$, número de hastes médio por planta $(\mathrm{H})$, produtividade de parte aérea da planta em $\left(\mathrm{t} \mathrm{ha}^{-1}\right)(\mathrm{PA})$, produtividade da matéria seca da parte aérea em $\left(\mathrm{t} \mathrm{ha}^{-1}\right)$ (MS PA), porcentagem de matéria seca da parte aérea (MS PA), na Fazenda Experimental Lageado, BotucatuSP, 2009 27

Tabela 13. Altura das plantas (cm) das variedades IAC14 e IAC576-70, Fazenda Experimental São Manuel, São Manuel - SP, 2009. 28

Tabela 14. Altura das plantas $(\mathrm{cm})$ das variedades IAC14 e IAC576-70, Fazenda Experimental Lageado, Botucatu - SP, 2009.

Tabela 15. Altura da primeira ramificação das plantas $(\mathrm{cm})$ das variedades IAC14 e IAC576-70, Fazenda Experimental São Manuel, São Manuel - SP, 2009. 30

Tabela 16. Altura da primeira ramificação das plantas $(\mathrm{cm})$ das variedades IAC14 e IAC576-70, Fazenda Experimental Lageado, Botucatu - SP, 2009. 31

Tabela 17. Diâmetro do caule $(\mathrm{cm})$ das plantas das variedades IAC14 e IAC576-70, Fazenda Experimental São Manuel, São Manuel - SP, 2009. 32

Tabela 18. Número de plantas por hectare no final do ciclo das variedades IAC14 e IAC576-70, Fazenda Experimental São Manuel, São Manuel - SP, 2009. 33

Tabela 19. Número de plantas por hectare no final do ciclo das variedades IAC14 e IAC576-70, Fazenda Experimental Lageado, Botucatu - SP, 2009. 34

Tabela 20. Produtividade da parte aérea $\left(\mathrm{t} \mathrm{ha}^{-1}\right)$ das plantas das variedades IAC14 e IAC576-70, Fazenda Experimental São Manuel, São Manuel - SP, 2009. 35

Tabela 21. Produtividade da parte aérea $\left(\mathrm{t} \mathrm{ha}^{-1}\right)$ das plantas das variedades IAC14 e IAC576-70, Fazenda Experimental Lageado, Botucatu - SP, 2009. 37

Tabela 22. Produtividade de matéria seca da parte aérea $\left(\mathrm{t} \mathrm{ha}^{-1}\right)$ das variedades IAC14 e IAC576-70, Fazenda Experimental São Manuel, São Manuel - SP, 2009. 38

Tabela 23. Produtividade de matéria seca da parte aérea $\left(\mathrm{t} \mathrm{ha}^{-1}\right)$ das variedades IAC14 e IAC576-70, Fazenda Experimental Lageado, Botucatu - SP, 2009. 39

Tabela 25. Resumo da análise de variância com valores de F calculados para as causas de variação e sua interação e médias para para a produtividade de cepa em $\mathrm{t} \mathrm{ha}^{-1}(\mathrm{t}$ cepa), produtividade de matéria seca cepa em $\mathrm{t} \mathrm{ha}^{-1}$ ( $\mathrm{t} \mathrm{MS}$ cepa), porcentagem de matéria seca cepa (\% MS cepa) diâmetro da raiz em $\mathrm{cm}$ (DR), comprimento da raiz em $\mathrm{cm}(\mathrm{CR})$, produtividade de raiz em $\mathrm{t} \mathrm{ha}^{-1}$ ( $\mathrm{t}$ raiz), 
produtividade de matéria seca da raiz em $\mathrm{t} \mathrm{ha}^{-1}$ ( $\mathrm{t}$ MS raiz), porcentagem matéria seca raiz (\% MS RAIZ) e porcentagem do índice de colheita (IC)Na Fazenda Experimental Lageado, Botucatu - SP, 2009 40

Tabela 26. Produtividade de cepa $\left(\mathrm{t} \mathrm{ha}^{-1}\right)$ das variedades IAC14 e IAC576-70. Fazenda Experimental São Manuel, São Manuel - SP, 2009.

Tabela 27. Produtividade de cepa $\left(\mathrm{t} \mathrm{ha}^{-1}\right)$ das variedades IAC14 e IAC576-70. Fazenda Experimental Lageado, Botucatu - SP, 2009.

Tabela 28. Produtividade de matéria seca das cepas $\left(\mathrm{t} \mathrm{ha}^{-1}\right)$ das variedades IAC14 e IAC576-70. Fazenda Experimental São Manuel, São Manuel - SP, 2009. 43

Tabela 29. Diâmetro das raízes (cm) das variedades IAC14 e IAC576-70. Fazenda Experimental São Manuel, São Manuel - SP, 2009. 46

Tabela 30. Diâmetro das raízes $(\mathrm{cm})$ das variedades IAC14 e IAC576-70. Fazenda Experimental Lageado, Botucatu - SP, 2009.

Tabela 31. Comprimento das raízes $(\mathrm{cm})$ das variedades IAC14 e IAC576-70. Fazenda Experimental Lageado, Botucatu - SP, 2009. 48

Tabela 32. Produtividade das raízes em $\mathrm{t} \mathrm{ha}^{-1}$ das raízes das variedades IAC14 e IAC576-70. Fazenda Experimental São Manuel, São Manuel - SP, 2009. 49

Tabela 33. Produtividade das raízes em $\mathrm{t} \mathrm{ha}^{-1}$ das variedades IAC14 e IAC576-70. Fazenda Experimental Lageado, Botucatu - SP, 2009 50

Tabela 34. Produtividade de matéria seca das raízes $\left(\mathrm{t} \mathrm{ha}^{-1}\right)$ das variedades IAC14 e IAC576-70. Fazenda Experimental São Manuel, São Manuel - SP, 2009.

Tabela 35. Produtividade de matéria seca das raízes $\left(\mathrm{t} \mathrm{ha}^{-1}\right)$ das variedades IAC14 e IAC576-70. Fazenda Experimental Lageado, Botucatu - SP, 2009.

Tabela 36. Índice de colheita (\%) das variedades IAC14 e IAC576-70. Fazenda Experimental São Manuel, São Manuel - SP, 2009. 53

Tabela 37. Índice de colheita (\%) das variedades IAC14 e IAC576-70. Fazenda Experimental Lageado, Botucatu - SP, 2009. 54

Tabela 38. Balanço de massa das raízes de mandioca nas variedades IAC14 e IAC576-70 no na Fazenda Experimental São Manuel em São Manuel-SP, 2009. 55

Tabela 39. Balanço de massa das raízes de mandioca nas variedades IAC14 e IAC576-70 na Fazenda Experimental Lageado em Botucatu-SP, 2009. .56 


\section{RESUMO}

A recomendação de um herbicida está condicionada a sua seletividade, ou seja, a sua capacidade de eliminar espécies vegetais indesejáveis sem promover reduções economicamente significativas, tanto na qualidade quanto na quantidade produzida pela cultura. A presente pesquisa avaliou a seletividade de herbicidas aplicados em pré e pós-emergência da cultura da mandioca cultivada considerando-se a intensidade de injuria na parte aérea, características morfológicas da planta, componentes da produtividade, produtividade e balanço de massa das raízes feculentas. Os experimentos foram instalados nos municípios de Botucatu/SP, Brasil em solo argiloso e em São Manuel/SP, Brasil em solo arenoso, no ano agrícola de 2008. Foi utilizado o delineamento em blocos ao acaso com quatro repetições, em esquema fatorial $11 \mathrm{X} 2$, sendo causa de variação dez herbicidas ametryne $\left(1000 \mathrm{~g} \mathrm{ha}^{-1}\right)$, clomazone $\left(500 \mathrm{~g} \mathrm{ha}^{-1}\right)$, ametryne + clomazone $\left(750+500 \mathrm{~g} \mathrm{ha}^{-1}\right)$ e atrazine $\left(500 \mathrm{~g} \mathrm{ha}^{-1}\right)$, aplicados logo após o plantio em pré-emergência da mandioca: haloxyfof-methyl (48 $\left.\mathrm{g} \mathrm{ha}^{-1}\right)$, sethoxydim (200 $\left.\mathrm{g} \mathrm{ha}^{-1}\right)$, fluazifop-p-butyl (100 $\left.\mathrm{g} \mathrm{ha}^{-1}\right)$, quizalofop-p-ethyl $\left(75 \mathrm{~g} \mathrm{ha}^{-1}\right)$, fomezafen $\left(225 \mathrm{~g} \mathrm{ha}^{-1}\right)$ e bentazon $\left(720 \mathrm{~g} \mathrm{ha}^{-1}\right)$, aplicados em pósemergência da cultura, mais uma testemunha capinada e duas variedades IAC14 e IAC576-70. Para a aplicação dos herbicidas foi utilizado um pulverizador costal, pressurizado a $\mathrm{CO}_{2}$ e equipado com barra de aplicação com cinco pontas Teejet XR 110 02vs espaçadas em 0,50m, com consumo de calda de $200 \mathrm{~L} \mathrm{ha}^{-1}$. A fitotoxicidade das plantas de mandioca foi avaliada visualmente valendo-se de uma escala percentual de notas, na qual "zero" correspondeu a nenhuma injúria e "cem" a morte das plantas. Antes da colheita foram avaliadas a altura das plantas $(\mathrm{cm})$, altura da primeira ramificação $(\mathrm{cm})$, diâmetro do caule $(\mathrm{cm})$, estande final de plantas por hectare, número médio de hastes por planta, após a colheita foram avaliada a massa verde da parte aérea e das cepas $\left(\mathrm{t} \mathrm{ha}^{-1}\right)$, 
massa seca da parte aérea e das cepas $\left(\mathrm{t} \mathrm{ha}^{-1}\right)$, porcentagem de raízes comerciais, comprimento e diâmetro das raízes $(\mathrm{cm})$, produtividade das raízes $\left(\mathrm{t} \mathrm{ha}^{-1}\right)$, porcentagem de matéria seca das raízes, índice de colheita (\%), balanço de massa das raízes (\%) e teor de amido (\%). Nos dois experimentos realizados, independente da variedade as moléculas de herbicidas ametryne, clomazone e a mistura de ametryne e clomazone aplicadas em pré-emergência, causaram injurias leves as plantas de mandioca. As moléculas fomezafen e bentazon, aplicadas em pós-emergência ocasionaram injurias severas as plantas de mandioca. Independente da molécula de herbicida aplicada nos dois experimentos à variedade IAC14 teve melhor desempenho nos parâmetros avaliados, particularmente a altura das plantas e produtividade. Pode se afirmar que a molécula clomazone no experimento realizado em Botucatu, independente da variedade testada possibilitou maior produtividade, o mesmo não ocorreu em São Manuel, onde não houve influencia dos herbicidas estudados na produtividade das variedades. A molécula fomezafen aplicada na variedade IAC14 proporcionou maior porcentagem de casca, os demais tratamentos não deferiram para o balanço de massa das raízes em ambos os experimentos. O teor de amido não foi afetado em ambas as variedades e ambientes estudados. Conclui-se que as moléculas de herbicidas estudadas são seletivas, em graus distintos, às variedades de mandioca avaliadas.

Palavras chaves: fitotoxicidade, moléculas de herbicidas, manihot esculenta, 
SELECTIVITY OF HERBICIDES THE CASSAVA. Botucatu, 2010. 65p. Dissertação (Mestrado em Agronomia/Agricultura) - Faculdade de Ciências Agronômicas, Universidade Estadual Paulista. Author: MAGNO LUIZ DE ABREU

Adviser: SILVIO JOSÉ BICUDO

Co-Adviser: DAGOBERTO MARTINS

\section{SUMMARY}

The herbicide recommendation is subjected to its selectivity and ability to eliminate undesirable species without promoting economically significant reductions in both quality and crop production. Thus, this work aimed to test the selectivity of herbicides applied in pre-and post-emergence of cassava crop considering the intensity of injury in the shoot, components of productivity, productivity end balance of mass of roots starch. The experiments were conducted in Botucatu / SP, Brazil, in a clay soil and São Manuel / SP, Brazil, in sandy soil, in 2008 croprowing season. The treatments was combinated in a $11 \times 2$ factorial (11 herbicides and 2 varieties) and disposed in a randomized block design. The treatments the herbicides tested was ametryne $(1000 \mathrm{~g}$ $\left.\mathrm{ha}^{-1}\right)$, clomazone $\left(500 \mathrm{~g} \mathrm{ha}^{-1}\right)$, ametryne + clomazone $\left(750+500 \mathrm{~g} \mathrm{ha}^{-1}\right)$ and atrazine $\left(500 \mathrm{~g} \mathrm{ha}^{-1}\right)$ applied in pre-emergence of cassava,haloxyfof-methyl (48 $\left.\mathrm{g} \mathrm{ha}^{-1}\right)$, sethoxydim $\left(200 \mathrm{~g} \mathrm{ha}^{-1}\right)$, fluazifop-p-butyl (100 $\left.\mathrm{g} \mathrm{ha}^{-1}\right)$, quizalofop-p-ethyl $\left(75 \mathrm{~g} \mathrm{ha}^{-1}\right)$, fomezafen $\left(225 \mathrm{~g} \mathrm{ha}^{-1}\right)$ and bentazon $\left(720 \mathrm{~g} \mathrm{ha}^{-1}\right)$, applied post-emergence of culture as well as an control untreated end two varieties IAC14 and IAC576-70. For the implementation it was used a backpack sprayer, pressurized CO2 and equipped with bar application with five Teejet XR $11002 \mathrm{vs}$ spaced at $0.50 \mathrm{~m}$, with consumption volume of $200 \mathrm{~L} \mathrm{ha}^{-1}$ of water. The phytotoxicity of the cassava plants was visually drawing on a percentage scale of notes, where zero corresponds to no injury and $100 \%$ the death of plants. Before harvest were evaluated plant height $(\mathrm{cm})$, height of first branch $(\mathrm{cm})$, stem diameter $(\mathrm{cm})$, final plant stand per hectare, the average number of stems per plant. After harvesting were assessed green mass shoot and the strains $\left(\mathrm{t} \mathrm{ha}^{-1}\right)$, shoots and strains dry weight $\left(\mathrm{t} \mathrm{ha}^{-1}\right)$, percentage of commercial roots, root length and diameter $(\mathrm{cm})$, final root yield $\left(\mathrm{t} \mathrm{ha}^{-1}\right)$, percentage of root dry 
mass of , harvest index (\%), rootmass balance (\%) and starch content (\%). In both experiments, regardless of the variety of herbicide molecules ametryne, clomazone, and the mixture of ametryne and clomazone applied pre-emergence caused light injuries to plant cassava. The fomezafen and bentazon molecules applied in post-emergence caused severe injuries to cassava plants. Regardless of herbicide molecule applied in both experiments, the variety IAC14 performs better in the parameters measured, which was also observed in the remaining parameters particularly plant height and productivity. It can be argued that the experiment in clomazone molecule studied in Botucatu, regardless of the variety tested to greater productivity, it does not occur in San Manuel, where no influence of herbicides on the productivity of the studied varieties. The fomezafen molecule applied in variety IAC14 showed higher percentage of bark, the rest of the treatments did not affect the mass balance of the varieties in both experiments. The starch content was not affected in both varieties and environments studied. It was possible to conclude that the herbicide molecules studied are selective, to varying degrees, the varieties of cassava evaluated.

Keywords: phytotoxicity, herbicide molecules, manihot esculenta. 


\section{INTRODUÇÃO}

A cultura da mandioca é tradicional nas regiões tropicais, como produtora de carboidratos e de considerável importância na alimentação humana e animal (ANDRADE, 1989), sendo aproveitado desde as folhas até as raízes. A mandioca ocupa posição de destaque na agricultura como um dos alimentos energéticos mais consumidos nos trópicos, sendo suplantada pelo arroz, cana-de-açúcar e milho. A parte economicamente mais importante da planta são as raízes tuberosas, ricas em amido, que além das utilizações já citadas são matéria-prima para indústrias alimentícia, farmacêutica, papel e têxtil (PERESSIN, 1997).

Como toda cultura agrícola, a mandioca está sujeita a uma série de fatores, bióticos e abióticos, que influenciam seu crescimento, desenvolvimento e produtividade econômica. Dentre esses fatores, destaca-se a interferência propiciada pela convivência da cultura com as plantas daninhas, as quais, segundo Lutman (1992), competem por água, luz e nutrientes, estando o grau de severidade dessa competição relacionado com o conjunto de espécies e densidade da comunidade infestante, sendo que a mandioca cultivada por até dois ciclos e o manejo das plantas daninhas torna-se bastante complexo, podendo reduzir drasticamente a produção de raízes (DEUBER, 1997).

Diversos autores têm procurado avaliar o período de competição entre a mandioca e as plantas daninhas que ocasiona as maiores perdas de produtividade. Pinho et al. (1980) relatam que capinas realizadas até 90 dias após o plantio aumentam consideravelmente a produção de ramas e raízes da mandioca. Alcântara \& Lima. (1982) evidenciaram que a manutenção da cultura no limpo a partir de 120 dias após o plantio não incrementou significativamente a produção. 
Em suma, a cultura é mais afetada pela interferência imposta pelas plantas daninhas durante os três ou quatro primeiros meses após o plantio.

A eliminação das invasoras representa cerca de 56\% da mão-de-obra utilizada no plantio e condução da mandioca, o que significa aproximadamente $30 \%$ do custo total de produção (MIRANDA et al., 1995). Na cultura da mandioca, os dois métodos mais utilizados para o controle de plantas daninhas são o mecânico, por meio de capinas, e o químico, pelo uso de herbicidas. No entanto, pouco se sabe a respeito da seletividade e eficácia de alternativas de controle químico de plantas daninhas na cultura da mandioca. Oliveira Jr. (1994), indica que a resposta da mandioca à aplicação de herbicidas varia desde a total seletividade até o completo comprometimento da produção, por causa da fitotoxicidade provocada à cultura. Tanto para a mandioca, como para qualquer outra espécie cultivada, a recomendação de um herbicida está condicionada a sua seletividade, ou seja, a sua capacidade de eliminar espécies vegetais indesejáveis sem promover reduções economicamente significativas, tanto na qualidade quanto na quantidade produzida pela cultura (VELINI et al., 2000). De maneira geral, devido às similaridades morfológicas e fisiológicas entre a cultura e as plantas daninhas, a aplicação de um herbicida pode ou não promover sintomas visuais de intoxicação às plantas cultivadas, sendo esta, o primeiro parâmetro avaliado na determinação da seletividade. Entretanto, no caso da ocorrência destes sintomas, geralmente caracterizados por injúrias foliares e paralisação de crescimento, não evoluírem provocando a morte dos indivíduos afetados, são considerados de pequena relevância se analisados de forma isolada (TERRA, 2003).

De outra forma, a ausência de injúrias visuais nas plantas tratadas com um determinado herbicida, também não é suficiente para determinar a sua tolerância a este produto, sendo necessária para tal, uma avaliação mais detalhada na quantidade e qualidade do seu produto final. Diante do exposto, a presente pesquisa avaliou a seletividade de herbicidas aplicados em pré e pós-emergência da cultura da mandioca cultivada considerando-se a intensidade de injuria na parte aérea, características morfológicas da planta, componentes da produtividade, produtividade e balanço de massa das raízes feculentas. 


\section{REVISÃO DE LITERATURA}

\subsection{Planta daninha}

As plantas daninhas competem com as culturas pelos nutrientes, luz, água, $\mathrm{CO}_{2}$ e espaço físico, representando uma importante limitação à produção agrícola. Além de sua presença causar grandes prejuízos, o seu controle acarreta também despesas que oneram substancialmente o custeio da cultura (PITELLI., 1980). Mascarenhas (1988), ainda ressalta que os prejuízos causados pelas plantas daninhas são de igual magnitude ou superiores aos ocasionados por insetos e doenças.

Estima-se que as perdas ocasionadas às culturas agrícolas pela interferência das plantas daninhas no Brasil dependendo da espécie pode chegar a $80 \%$. Além da redução quantitativa da produção, esta pode ser qualitativamente depreciada pela contaminação com sementes e restos de plantas daninhas. Em cereais, adicionalmente, aumentam o teor de umidade dos grãos, diminuindo a eficiência agrícola. Diante da grande necessidade de se produzir cada vez mais de maneira eficiente, as plantas daninhas se tornam um problema que merece especial atenção dos profissionais da agricultura (LORENZI., 2006).

\subsection{Controle de plantas daninhas}

Segundo Lorenzi (2006), o controle de plantas daninhas consiste na adoção de certas práticas que resultam na redução da infestação, mas não necessariamente, na sua completa 
eliminação: isto é a erradicação. O controle ideal, porém, é dificilmente obtido na agricultura. Muitas são as formas de controle das plantas daninhas, dentre elas podemos citar: controle preventivos; que consiste no uso de práticas que visam prevenir a introdução, estabelecimento e/ou a disseminação de determinadas espécies em áreas ainda por elas não infestadas; Controle cultural; o qual consiste no uso de práticas comuns ao bom manejo da água e do solo, como a rotação de cultura, a variação do espaçamento da cultura e o uso de coberturas verdes; Controle mecânico ou físico que conforme o próprio nome indica, consiste no uso de práticas de eliminação de plantas daninhas através do efeito físico-mecânico, como o arranquio manual, a capina manual, a roçada, a inundação, a queima, a cobertura morta e o cultivo mecanizado; Controle biológico; envolvendo primariamente o uso de inimigos naturais (pragas e doenças), para o controle de plantas daninhas; Por extensão, também deve ser considerado como controle biológico a inibição alelopática de plantas daninhas exercida por outras plantas; O controle químico: que é o método mais utilizado para controle de plantas daninhas e consiste na aplicação de produtos químicos que eliminam ou inibe o desenvolvimento das plantas (LORENZI, 2003).

\subsection{Controle químico}

O controle químico é o método mais utilizado para controlar as invasoras. Suas vantagens são a economia de mão de obra e a rapidez na aplicação. Para que a aplicação dos herbicidas seja segura, eficiente e econômica, exigem-se técnicas refinadas. O reconhecimento prévio das invasoras predominantes é condição básica para a escolha adequada do produto, que resultará no controle mais eficiente das invasoras (RAJCAN \& SWANTON, 2001).

A eficiência dos herbicidas aumenta quando aplicados em condições favoráveis. É fundamental que se conheça as especificações do produto antes de sua utilização e que se regule corretamente o equipamento de pulverização para evitar riscos de toxicidade ao homem e à cultura. Segundo Embrapa, (2006) os herbicidas são classificados quanto à época de aplicação, em pré-plantio, pré-emergentes e pós-emergentes.

A mandioca é uma planta que apresenta boa tolerância a vários herbicidas, quando aplicados antes de sua brotação e nas doses recomendadas (SILVA et al., 2009). Segundo Carvalho et al., (1990), já em 1990, a maioria dos herbicidas utilizados em mandioca é de préemergência total, antes da germinação do mato e da brotação da cultura, e aplicados logo após o plantio ou, no máximo, cinco dias depois, sendo que a escolha do herbicida é conseqüência direta das espécies de plantas daninhas presentes e do seu custo que atualmente é p principal fator. 
Lorenzi, 2003 recomenda os herbicidas à base de glifosate em aplicações dirigidas, evitando atingir as folhas da cultura e quando a cultura da mandioca esteja com aproximadamente cinco meses apresentando 30 a $40 \mathrm{~cm}$ de haste em relação ao solo. O glifosate é também bastante empregado para o controle de plantas daninhas após a poda, podendo acrescentado um herbicida pré-emergente para aumentar o período residual.

\subsection{Eficiência e seletividade dos herbicidas na cultura da mandioca}

Oliveira Jr et al. (2001), avaliaram a tolerância dos cultivares de mandioca Espeto, Mico, Fécula Branca, IAC-14 e Fibra aos herbicidas metribuzin (490 g i.a. ha ${ }^{-1}$ ), clomazone $\left(1000\right.$ g i.a. $\left.\mathrm{ha}^{-1}\right)$, mistura formulada de ametryne + clomazone $\left(2500 \mathrm{~g}\right.$ i.a. ha $\left.{ }^{-1}\right)$ e ametryne + trifluralin $\left(1500+1800 \mathrm{~g}\right.$ i.a. $\left.\mathrm{ha}^{-1}\right)$. O tratamento com ametryne + trifluralin foi o mais seletivo para a cultura, e a mistura formulada de ametryne + clomazone, nos cultivares Mico e Fécula Branca, causou sintomas visuais de fitotoxicidade aos 51 dias após o plantio. Nenhum dos tratamentos químicos afetou o estande ou o crescimento da cultura.

Oliveira Jr et al. (2001b) em outro trabalho avaliaram a seletividade e eficácia de diversos herbicidas aplicados na cultura da mandioca em plantio direto e observaram que clethodin, fenoxaprop-p-ethyl e sethoxydin não causaram injúria considerável às plantas, seguidos do propaquizafop, com baixa porcentagem de toxicidade às plantas de mandioquinhasalsa. O bentazon e o amônio-glufosinato proporcionaram alta toxicidade no início das avaliações, mas a partir de 28 e 35 dias após a aplicação (DAA), respectivamente, observou-se boa recuperação das plantas. Na dose utilizada, linuron e oxadiazon causaram baixa toxicidade, cujos sintomas desapareceram aos 28 (DAA). Em relação à parte subterrânea, o amônio-glufosinato proporcionou o menor peso de matéria seca quando comparado ao fenoxaprop-p-ethyl e à testemunha. Os herbicidas seletivos não apresentaram efeitos significativos em relação ao número de brotações, número de folhas e altura de plantas. Os herbicidas flazasulfuron e imazamox não foram seletivos à cultura, proporcionando injúrias severas até a morte das plantas.

Biffe et al. (2007) em estudo com o herbicida diuron em pré-emergência total na cultura da mandioca observaram que o produto nas doses de 625,0; 750,0 e 900,0 g i.a. ha ${ }^{-1}$, proporcionaram um controle satisfatório para seguintes espécies: Digitaria horizontalis, Acanthospermum hispidum, Amaranthus viridis, Sida rhombifolia, Sida cordifolia, Bidens. E quanto à fitointoxicação, nas doses testadas, o herbicida diuron apresentou sintomas visuais na cultura da mandioca até os 30 DAA. Porém, aos 45 DAA, as plantas avaliadas nos tratamentos com herbicida 
já se recuperaram e igualaram as testemunhas. Em outro estudo, Alonso et al. (2007a) avaliaram o efeito do herbicida alachlor, aplicado em pré-emergência, no controle de plantas daninhas na cultura da mandioca e concluiram que o produto aplicado nas doses de 1920,0;2400,0 e 2880,0 g i.a. ha ${ }^{-1}$, apresentou efetivo controle de Cenchrus echinatus,Digitaria horizontalis e Commelina benghalensis. No entanto, o mesmo não se aplica a Brachiaria decumbens, pois todas as doses de Alachlor aos 45 DAA não foram eficazes para o controle desta planta daninha. O herbicida Alachlor na sua maior dose pode ser ainda utilizado para controlar a Brachiaria plantaginea.O herbicida alachlor, independente da dose, não prejudicou a mandioca nos aspectos de estande, altura e desenvolvimento até os 45 DAA.

Alonso et al. (2007b) avaliaram a eficácia e viabilidade do herbicida trifluralin na cultura da mandioca e concluiram que o herbicida apresenta bons resultados de controle de Brachiaria decumbens, Brachiaria plantaginea, Eleusine indica e Digitaria horizontalis, em doses superiores à $1350 \mathrm{~g}$ i.a. ha ${ }^{-1}$, sem afetar a cultura da mandioca.

Arantes et al. (2007) estudaram a seletividade de diferentes alternativas de herbicidas pré-emergentes para a cultura da mandioca, variedade Fécula Branca, em casa-devegetação. As características avaliadas foram de fitointoxicação (escala visual, 0-100\%), aos 91, 97, 104 e 111 DAA e a biomassa das folhas, caules e raízes das plantas aos 111 DAA e concluíram que a fitotoxicidade observada não afetou o acúmulo total de biomassa seca das plantas de mandioca.

\subsection{Herbicidas registrados}

Em decorrência da cultura da mandioca ser uma cultura que não apresenta um grande impacto no cenário produtivo nacional quando comparado a culturas de maior expressão como soja, milho e cana-de-açúcar, não existe grande interesse por parte de empresas de defensivos em registrarem seus produtos para a esta cultura. Isso explica em parte o porque de existir poucos produtos registrados para a cultura, apesar da pesquisa já ter comprovado através de vários ensaios experimentais, a eficácia e seletividade de determinados produtos (SILVA et al., 2009). 
Tabela 1. Herbicidas registrados para uso na cultura da mandioca, com suas respectivas épocas de aplicação e dosagens recomendadas, Botucatu-SP, 2010.

Herbicidas

\begin{tabular}{lllll}
\hline \multicolumn{1}{c}{ Molécula } & Nome do produto & \multicolumn{1}{c}{ Grupo Químico } & Época de aplicação & Dose i a ha \\
\hline ametryna & Ametrex 500 SC & Triazina & Pré & 3000 \\
clethodin & Select 240 CE & Oxima ciclohexanodiana & Pós & 100 \\
clomazone & Gamit & Isoxazolidinona & Pré & 2000 \\
isoxaflutole & WG & Isoxazol & Pré & 200 \\
metribuzin & Sencor & Triazinona & Pós & 420 \\
\hline
\end{tabular}

Pré - Aplicação em pré-emergência da cultura

Pós - Aplicação em pós-emergência da cultura

Fonte: MAPA, 2009. 


\section{MATERIAL E MÉTODOS}

\subsection{Localização e data}

Os ensaios de campo foram instalados na Fazenda Experimental Lageado, no dia 16 de outubro de 2008 e colhidos em 10 de agosto 2009, no município de Botucatu-SP, localizado na região centro-sul do Estado de São Paulo, localizada nas coordenadas $22^{\circ} 52^{\prime} 20^{\prime \prime}$ latitude S e 48 26’37' longitude W de Greenwich e altitude de 804 m, e na Fazenda Experimental São Manuel, no dia 02 de dezembro e colhido em 30 de agosto de 2009, no município de São Manuel-SP, localizado nas coordenadas geográficas de $22^{\circ} 44^{\prime} \mathrm{S}$ e $48^{\circ} 34^{\prime} \mathrm{W}$ com altitude de $750 \mathrm{~m}$. Ambas as Fazendas são pertencentes à Faculdade de Ciência Agronômicas da Universidade Estadual paulista, UNESP/BOTUCATU.

\subsection{Descrição de clima e solo}

Os municípios de Botucatu e de São Manuel tem a mesma classificação climática pelo método de Köppen, classificada como sendo Cfa, clima temperado quente (mesotérmico) úmido, e a temperatura média do mês mais quente é superior a $22{ }^{\circ} \mathrm{C}$. Pela classificação de Thornthwaite tem uma pequena diferença em função do índice de umidade, caracterizando como B2rB'3a' (clima úmido com pequena deficiência hídrica - abril, julho e agosto, mesotérmico, com evapotranspiração potencial anual de $945,15 \mathrm{~mm}$ e concentração da evapotranspiração potencial no verão igual a 33\%). Segundo Cunha \& Martins (2009), nas figuras 1 e 2, estão dispostos os dados coletados em estação de aquisição de dados meteorológicos próximo as áreas experimentais. O tipo de solo da área Experimental da Fazenda Lageado esta classificado 
como Nitossolo vermelho distroférrico (Embrapa, 1999) e na Fazenda Experimental São Manuel classificado como Latossolo Vermelho Distrófico Típico (Embrapa, 1999). A caracterizações física e química encontram-se nas Tabelas 2, 3, 4, 5, 6 e 7 .

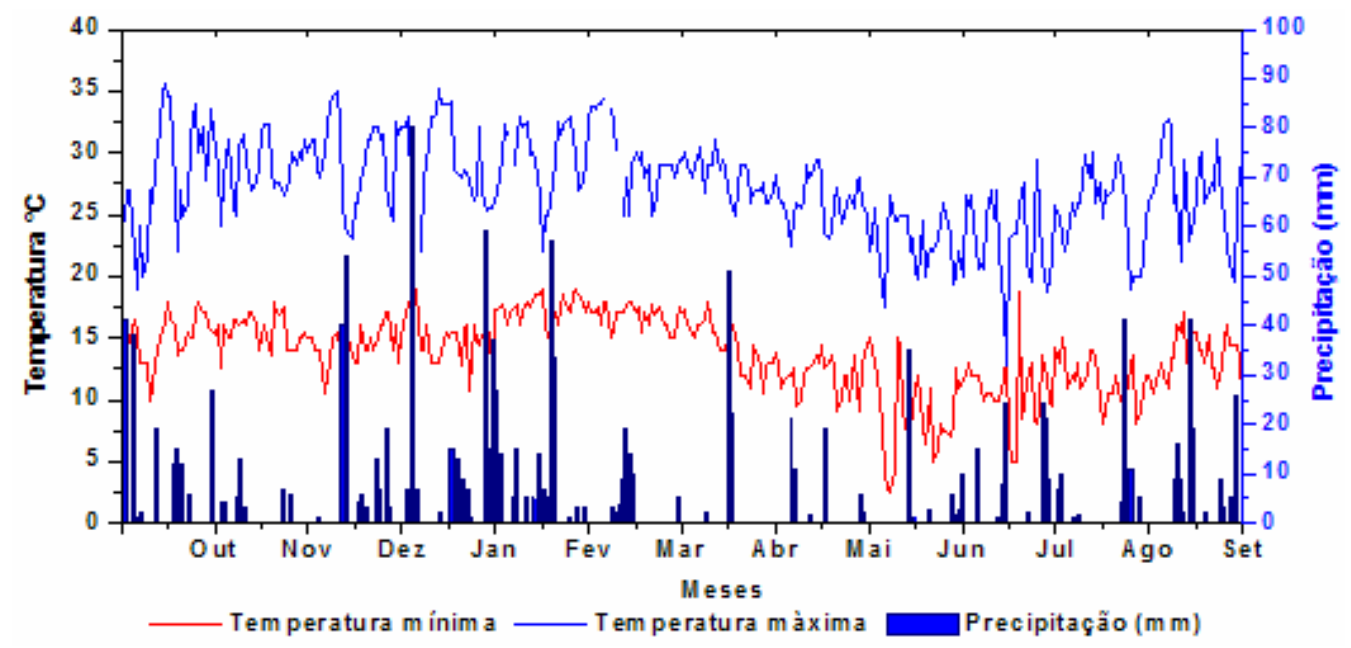

Figura 1. Dados climatológicos do período de Dezembro de 2008 a Setembro de 2009 em São Manuel (SP).

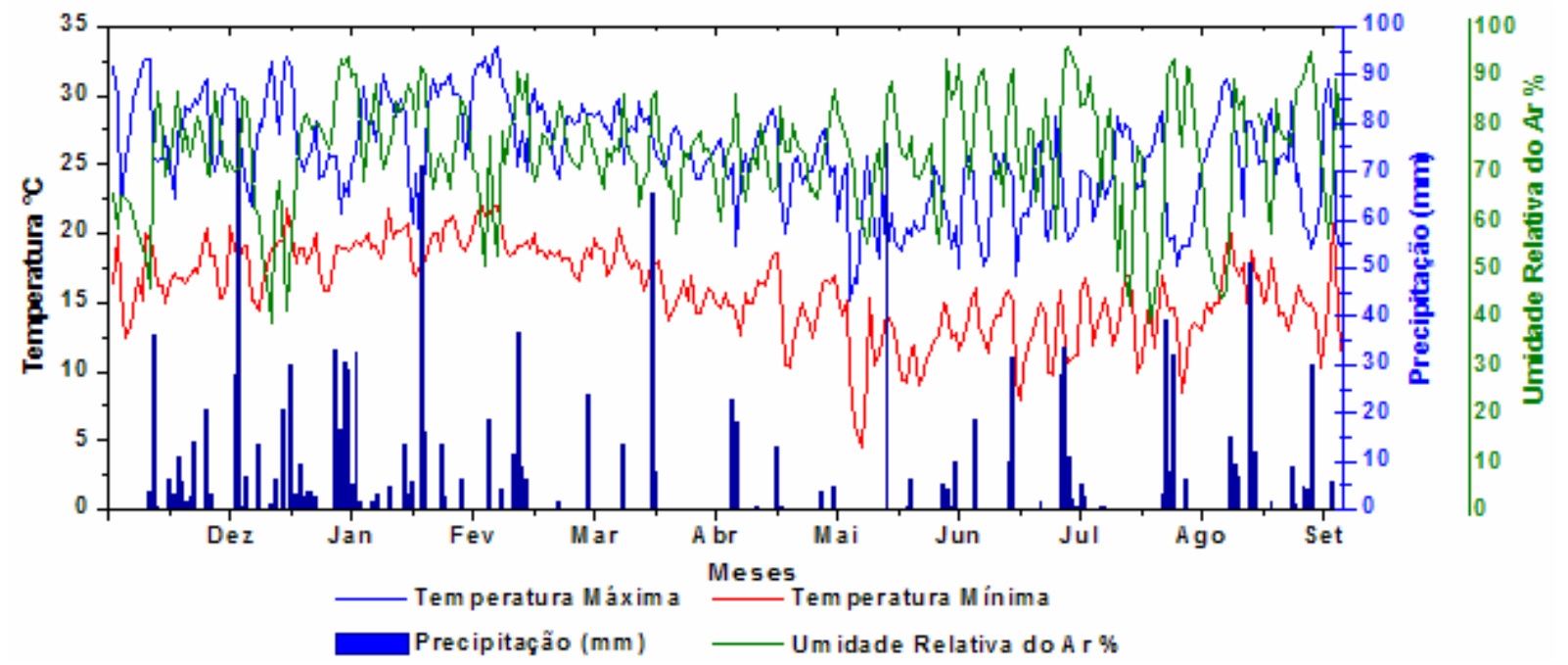

Figura 2. Dados climatológicos do período de Dezembro de 2008 a Setembro de 2009 em Botucatu (SP). 
Tabela 2. Resultados da análise química do solo na profundidade $0-20 \mathrm{~cm}$, amostrado antes da instalação do experimento, Fazenda Experimental São Manuel em São Manuel - SP, 2010.

\begin{tabular}{cccccccc}
\hline $\mathbf{p H}$ & $\mathbf{M O}$ & $\begin{array}{c}\mathbf{P} \\
\text { (resina) }\end{array}$ & $\mathbf{H}+\mathbf{A l}$ & $\mathbf{K}$ & $\mathbf{C a}+\mathbf{M g}$ & $\mathbf{C T C}$ & $\mathbf{V}$ \\
\hline $\mathrm{CaCl}_{2}$ & $\mathrm{~g} \mathrm{dm}^{-3}$ & $\mathrm{mg} \mathrm{dm}^{-3}$ & & & & \\
\hline 5,8 & 10 & 11 & 26 & 10 & 22 & 33 & 70
\end{tabular}

Fonte: Laboratório de Fertilidade do Solo do Departamento de Recursos Naturais da Faculdade de Ciências Agronômicas da Unesp, Campus de Botucatu.

Tabela 3. Resultados da análise química do solo na profundidade $0-20 \mathrm{~cm}$, amostrado antes da instalação do experimento na Fazenda Experimental Lageado em Botucatu - SP, 2010.

\begin{tabular}{cccccccc}
\hline $\mathbf{p H}$ & $\mathbf{M O}$ & $\begin{array}{c}\mathbf{P} \\
\text { (resina) }\end{array}$ & $\mathbf{H}+\mathbf{A l}$ & $\mathbf{K}$ & $\mathbf{C a} \mathbf{M g}$ & $\mathbf{C T C}$ & $\mathbf{V}$ \\
\hline $\mathrm{CaCl}_{2}$ & $\mathrm{~g} \mathrm{dm}^{-3}$ & $\mathrm{mg} \mathrm{dm}{ }^{-3}$ & $----------------\mathrm{mmol}_{\mathrm{c}} \mathrm{dm}^{-3}$ & & $\%$ \\
\hline 5,6 & 29 & 17 & 30 & 3,2 & 52 & 85 & 65 \\
\hline
\end{tabular}

Fonte: Laboratório de Fertilidade do Solo do Departamento de Recursos Naturais da Faculdade de Ciências Agronômicas da Unesp, Campus de Botucatu.

Tabela 4. Resultados da análise química de micronutrientes do solo na profundidade 0$20 \mathrm{~cm}$, amostrado antes da instalação do experimento, Fazenda Experimental São Manuel em São Manuel - SP, 2010.

\begin{tabular}{|c|c|c|c|c|}
\hline $\bar{B}$ & $\mathbf{C u}$ & $\mathbf{F e}$ & Mn & $\mathrm{Zn}$ \\
\hline \multicolumn{5}{|c|}{ 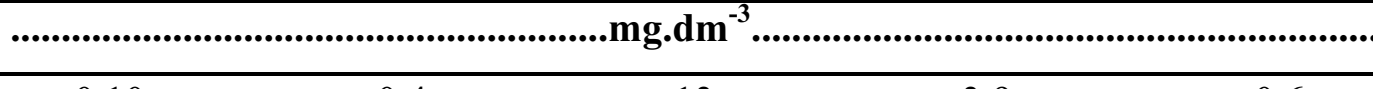 } \\
\hline 0,10 & 0,4 & 13 & 3,9 & 0,6 \\
\hline
\end{tabular}

Fonte: Laboratório de Fertilidade do Solo do Departamento de Recursos Naturais da Faculdade de Ciências Agronômicas da Unesp, Campus de Botucatu.

Tabela 5. Resultados da análise química de micronutrientes do solo na profundidade 0$20 \mathrm{~cm}$, amostrado antes da instalação do experimento, Fazenda Experimental Lageado em Botucatu - SP, 2010.

\begin{tabular}{|c|c|c|c|c|}
\hline B & $\mathrm{Cu}$ & $\mathrm{Fe}$ & Mn & $\mathbf{Z n}$ \\
\hline \multicolumn{5}{|c|}{ 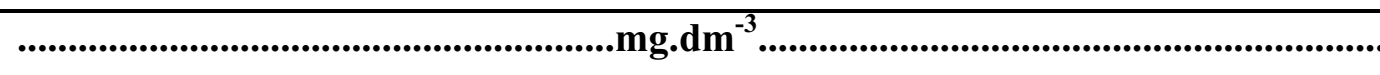 } \\
\hline 0,29 & 7,9 & 17 & 36,6 & 1,8 \\
\hline
\end{tabular}

Fonte: Laboratório de Fertilidade do Solo do Departamento de Recursos Naturais da Faculdade de Ciências Agronômicas da Unesp, Campus de Botucatu. 
Tabela 6. Resultado da análise física do solo na profundidade de $0-20 \mathrm{~cm}$, amostrados antes da instalação do experimento, Fazenda Experimental São Manuel em São Manuel - SP, 2010.

\begin{tabular}{|c|c|c|c|c|}
\hline Profundidade & Areia & Argila & Silte & Textura \\
\hline $\mathrm{cm}$ & & $\mathrm{g} \mathrm{kg}$ & & \\
\hline $0-20$ & 883 & 80 & 37 & Arenosa \\
\hline
\end{tabular}

Tabela 7. Resultado da análise física do solo na profundidade de $0-20 \mathrm{~cm}$, amostrados antes da instalação do experimento, Fazenda Experimental Lageado em Botucatu - SP, 2010.

\begin{tabular}{ccccc}
\hline Profundidade & Areia & Argila & Silte & Textura \\
\hline $\mathrm{cm}$ & & $\mathrm{g} \mathrm{kg}^{-1}$ & & \\
\hline $0-20$ & 210 & 574 & 216 & Argilosa \\
\hline
\end{tabular}

\subsection{Idade das plantas e manivas utilizadas no plantio}

As ramas utilizadas estavam com um ciclo e idades de 11 a 14 meses. A seleção das manivas para o plantio foi feita procurando uniformizar ao máximo o material utilizado. Foram usadas as frações do terço médio da planta, com $20 \mathrm{~cm}$ de comprimento e aproximadamente 2,5 cm de diâmetro, perfazendo a média de 5 gemas. O corte, feito em máquina de serra fita, baseados em recomendação de Lorenzi et al., (2003).

\subsection{Preparo do solo, plantio e adubação}

Foi realizado o mesmo preparo de solo nos dois experimentos, sendo esse de forma convencional, com uma aração e duas gradagens. Procedeu-se a abertura dos sulcos com sulcador tratorizado com o espaçamento utilizado de $0.85 \mathrm{~m}$ entre linhas e de acordo com a análise de solo foi realizada a adubação com $300 \mathrm{~kg} \mathrm{ha}^{-1}$ de adubo da formulação 8-28-16, no momento da sulcação. As manivas sementes foram distribuídas nos sulcos de plantio em espaçamento de $0.80 \mathrm{~m}$ entre elas. 


\subsection{Tratos culturais}

Durante o ciclo de desenvolvimento da cultura foram realizadas 4 capinas manuais nas parcelas tratadas com os herbicidas e testemunha mantida no limpo para evitar a interferência das plantas daninhas.

\subsection{Delineamento Experimental e cultivares utilizadas}

Os experimentos foram instalados no delineamento de blocos casualizadas com quatro repetições em esquema fatorial ( 2 X 11) com duas variedades e onze tratamentos. Cada parcela foi constituída de 4 linhas de $8 \mathrm{~m}$ de comprimento, com espaçamento de $0,85 \mathrm{~m}$ entre linhas.

As cultivares utilizadas foram IAC 576-70 que se destaca por sua adaptação edafoclimáticas as áreas de plantio de mandioca de mesa do Estado de São Paulo (LORENZI, 2003). A cultivar foi desenvolvida pelo Instituto Agronômico de Campinas (IAC) a partir do cruzamento entre SRT797 Ouro do Vale e IAC 14-18, apresentando superioridade aos demais cultivares em cultivo no Estado, por sua produtividade, aspecto agradável das raízes, qualidades culinárias e sensoriais, e considerável resistência à bacteriose (LORENZI ET AL, 1984). Suas raízes possuem película suberosa de cor marrom, lisa e de forma predominantemente cilíndrica, feloderma e polpa de coloração creme. Apresenta polpa de coloração amarela quando cozida. Possuí broto verdearroxeado, hastes jovens verdes, pecíolos verde-amarelados, folhas largas com cinco a sete lóbulos, ramificação di e tricotômica, com ângulo ao redor de $45^{\circ}$, e hastes maduras cinzas verdeadas (LORENZI et al, 1996).

A cultivar IAC14 foi selecionada dentro de uma população de 180 mil clones, formada pela recombinação de nove variedades elite: Vassourinha Paulista, Branca de Santa Catarina, Roxinha, Taquari, Engana Ladrão, IAC14-18, IAC12, Aipim Bravo e IAC Caipora. Essa variedade é altamente produtiva e tem alta resistência a bacteriose e ao superalongamento. As raízes possuem alto teor de matéria seca e a película é de cor marrom-escura, limitando em parte, seu uso para a produção de farinha. Possui broto roxo esverdeado, haste jovem verde, hastes maduras arroxeadas, pecíolo verde arroxeado, lóbulo foliar obovado e liso, altura média para alta da primeira ramificação (LORENZI, 2003). 
Tabela 8. Descrição dos tratamentos aplicados.

\begin{tabular}{ccccc}
\hline Tratamento & Moléculas utilizadas & Época de aplicação & Variedade & Dose $\mathbf{g}$ i. a / $\mathbf{g ~ h a}^{-1}$ \\
\hline $\mathbf{1}$ & ametryne & Pré & IAC14 & 1000 \\
$\mathbf{2}$ & ametryne & Pré & IAC576-70 & 1000 \\
$\mathbf{3}$ & clomazone & Pré & IAC14 & 500 \\
$\mathbf{4}$ & clomazone & Pré & IAC576-70 & 500 \\
$\mathbf{5}$ & ametryne+ clomazone & Pré & IAC14 & $750+500$ \\
$\mathbf{6}$ & ametryne + clomazone & Pré & IAC576-70 & $750+500$ \\
$\mathbf{7}$ & atrazine & Pré & IAC14 & 500 \\
$\mathbf{8}$ & atrazine & Pré & IAC576-70 & 500 \\
$\mathbf{9}$ & haloxyfof-methyl & Pós & IAC14 & 48 \\
$\mathbf{1 0}$ & haloxyfof-methyl & Pós & IAC576-70 & 48 \\
$\mathbf{1 1}$ & Sethoxidim & Pós & IAC14 & 200 \\
$\mathbf{1 2}$ & Sethoxidim & Pós & IAC576-70 & 200 \\
$\mathbf{1 3}$ & fluazifop-P-butil & Pós & IAC14 & 100 \\
$\mathbf{1 4}$ & fluazifop-P-butil & Pós & IAC576-70 & 100 \\
$\mathbf{1 5}$ & quizalofop-P-ethyl & Pós & IAC14 & 75 \\
$\mathbf{1 6}$ & quizalofop-P-ethyl & Pós & IAC576-70 & 75 \\
$\mathbf{1 7}$ & fomezafen & Pós & IAC14 & 225 \\
$\mathbf{1 8}$ & fomezafen & Pós & IAC576-70 & 225 \\
$\mathbf{1 9}$ & bentazon & Pós & IAC14 & 720 \\
$\mathbf{2 0}$ & bentazon & Pós & IAC576-70 & 720 \\
$\mathbf{2 1}$ & testemunha capinada & ---- & IAC14 & ---- \\
$\mathbf{2 2}$ & testemunha capinada & ---- & IAC576-70 & ---- \\
\hline
\end{tabular}

Pré - Aplicação em pré-emergência da cultura

Pós - Aplicação em pós-emergência da cultura

Os herbicidas em pré-emergência foram aplicadas logo após o plantio e os produtos com aplicação em pós-emergência aos oito dias após a emergência da cultura na Fazenda Experimental São Manuel, em São Manuel e, aos dez dias após a emergência das plantas de mandioca na Fazenda Experimental Lageado, em Botucatu-SP.

\subsection{Equipamento e aplicação dos herbicidas}

A aplicação dos herbicidas em pré-emergência no experimento instalado na Fazenda Experimental de São Manuel foi realizada no dia 18/10/2008, logo após o plantio, tendo como condições climáticas: temperatura do ar média de $26,5^{\circ} \mathrm{C}$, umidade relativa do ar de $60 \% \mathrm{e}$ vento de 4,3 $\mathrm{km} \mathrm{h}^{-1}$. As aplicações em pós-emergência foram realizada no dia 13/11/2008, sendo que suas condições de clima apresentavam temperatura média de $24^{\circ} \mathrm{C}$, umidade relativa do ar de $69 \%$ e vento de $4 \mathrm{~km} \mathrm{~h}^{-1}$. A aplicação dos herbicidas no experimento instalado na Fazenda Lageado 
em pré-emergência, foi realizada no dia 13/12/2008 logo após o plantio, onde as condições climáticas eram: temperatura do ar média de $25^{\circ} \mathrm{C}$, umidade relativa do ar de $63 \%$ e vento de $4,1 \mathrm{~km}$ $\mathrm{h}^{-1}$. Em pós-emergência foi aplicado no dia 22/01/2009, com temperatura do ar média de $22,5^{\circ} \mathrm{C}$, umidade relativa do ar de $80 \%$ e vento de $5,0 \mathrm{~km} \mathrm{~h}^{-1}$. O equipamento utilizado na aplicação dos tratamentos foi um pulverizador costal, pressurizado a $\mathrm{CO}_{2}$ mantendo-se uma pressão constante de $2,0 \mathrm{kgf} \mathrm{\textrm {cm } ^ { - 2 }}$ e equipado com barra de aplicação munida com cinco pontas de pulverização Teejet XR 110 02VS, com consumo de calda. Utilizou-se o volume de aplicação de $200 \mathrm{~L} \mathrm{ha}^{-1}$.

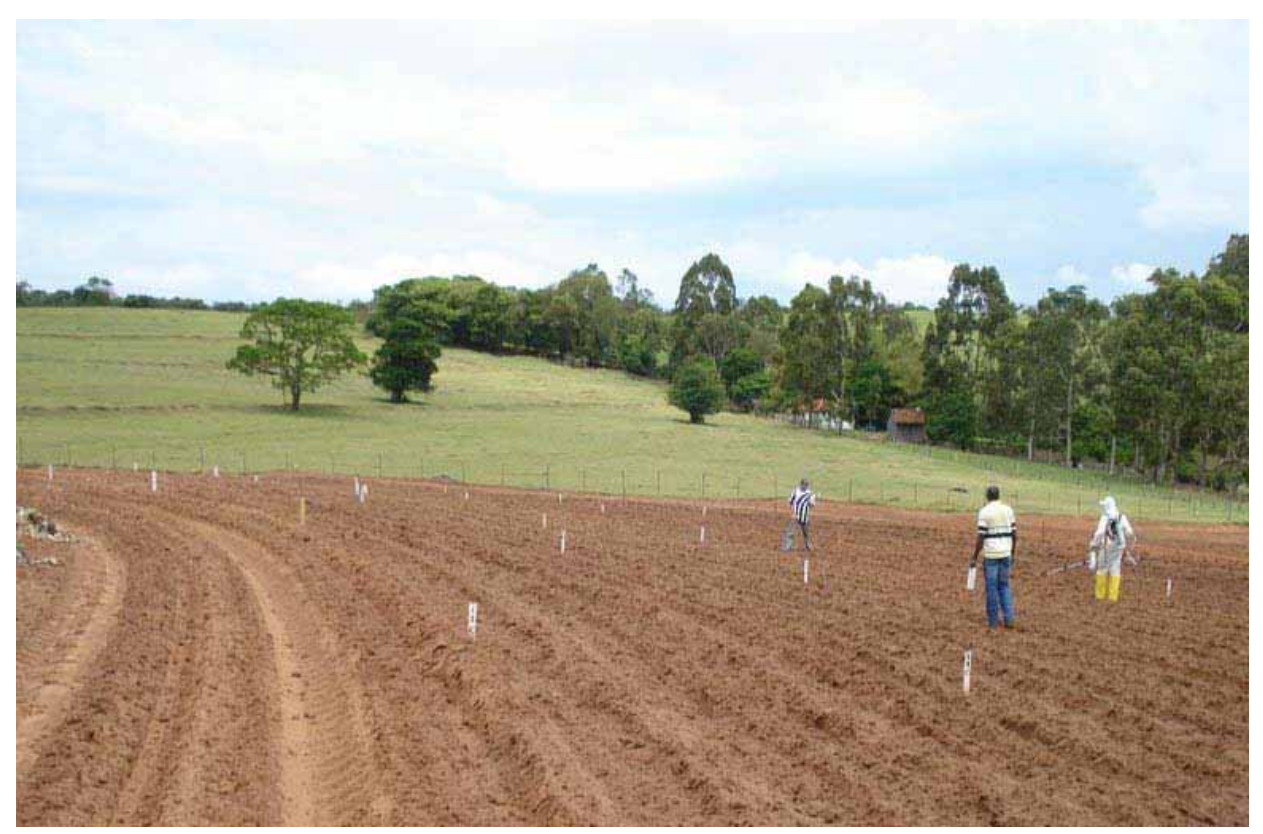

Figura 4. Aplicação dos herbicidas na área Experimental.

\subsection{Características avaliadas}

\subsubsection{Fitotoxicidade das plantas}

A fitotoxicidade das plantas de mandioca foi avaliada visualmente valendose de uma escala percentual de notas, na qual "(zero 0\%)" correspondeu a nenhuma injúria e "(cem 100\%)" a morte das plantas, segundo a Sociedade Brasileira da Ciência das Plantas Daninhas (1995).

As avaliações visuais realizadas nos tratamentos de pré e pós-emergência na Fazenda Experimental São Manuel, foram feitas após a brotação de todas as manivas sementes na seguinte ordem 10, 17, 22, 29, 39 e 49 dias após a emergência das plantas de mandioca. Na Fazenda Lageado as avaliações foram realizadas aos 12, 19, 26, 33, 40 e 47 dias após a emergência das plantas de mandioca. 


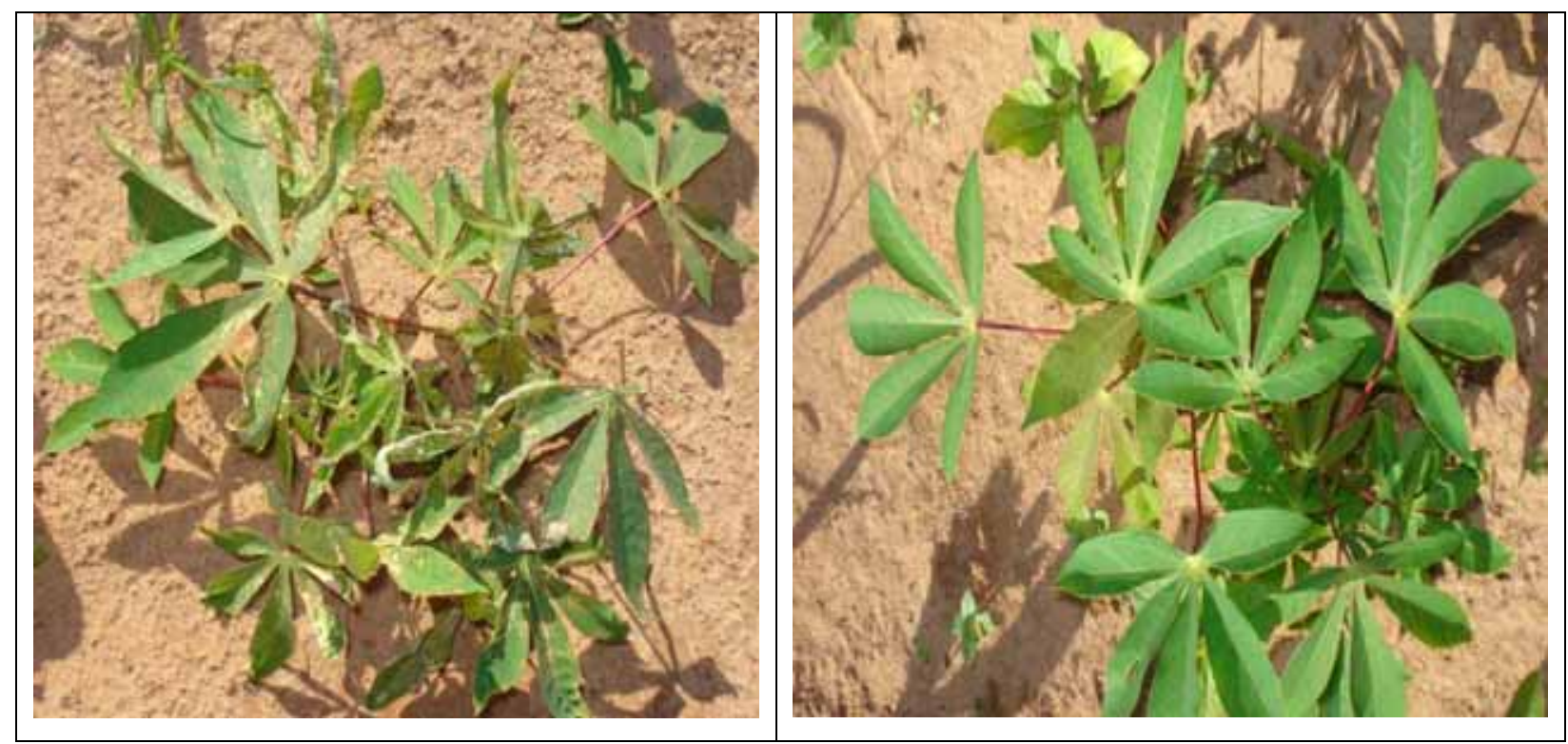

Figura 5. Comparação de uma planta com injuria causada pela aplicação do herbicida com outra planta sem injuria na Fazenda Experimental São Manuel em São Manuel -SP, na variedade IAC14, avaliadas aos 19 dias após a emergência das plantas de mandioca.

\subsubsection{Altura do dossel, altura primeira ramificação e diâmetro do caule das plantas}

A altura do dossel foi feita com uma trena comum, medindo-se da superfície do solo até o ponto mais alto das plantas. A altura da primeira ramificação foi feita com a mesma trena, medindo-se da superfície do solo até a primeira ramificação da planta, sendo a medida do diâmetro do caule realizada com paquímetro digital a $10 \mathrm{~cm}$ do solo.

\subsubsection{Estande final}

O estande final foi determinado na área útil da parcela, $\left(27 \mathrm{~m}^{2}\right)$, um dia antes da colheita e posteriormente, transformando para número de plantas por hectare.

\subsubsection{Número de hastes por planta}

O número de hastes por planta foi determinado um dia antes da colheita, em todas as plantas da área útil, sendo contadas as hastes nas plantas úteis, e este número dividido pelo número de plantas úteis. 
5.8.5 Massa verde da parte aérea e cepas.

A parte aérea foi considerada a partir de $10 \mathrm{~cm}$ do solo e as cepas a porção restante das ramas acrescidos dos segmentos abaixo do solo, retirando-se as raízes tuberosas, sendo os valores convertidos para $\mathrm{tha}^{-1}$.

\subsubsection{Massa seca da parte aérea e cepas.}

As amostras para a determinação de massa seca foram coletadas nas parcelas, trituradas e secas em estufa com circulação de ar forçado a $65^{\circ} \mathrm{C}$, até massa constante e convertidas para $\mathrm{tha}^{-1}$.

\subsubsection{Número de raízes comerciais e descartáveis}

Foram separadas todas as raízes que apresentavam tamanho reduzido e anomalias, posteriormente contadas e subtraídas do número total de raízes da parcela, determinando sua porcentagem por hectare.

\subsubsection{Comprimento e diâmetro das raízes tuberosas}

O comprimento foi determinado com trena comum, medindo-se toda a extensão da raiz. O diâmetro da raiz foi realizado com paquímetro digital, no terço médio da raiz.

\subsubsection{Produtividade}

Foram consideradas todas as raízes tuberosas, mesmo aquelas de tamanho reduzido. Todas as raízes da área útil tiveram sua massa determinada e transformada em $\mathrm{tha}^{-1}$.

\subsubsection{Matéria seca das raízes}

Foram colhidas e pesadas amostras de mandioca e posteriormente colocadas em estufas a $65^{\circ} \mathrm{C}$ até peso constante. 


\subsubsection{1 Índice de colheita}

O I.C em porcentagem foi determinado adotando-se a seguinte relação: $\mathrm{IC}=$ massa fresca das raízes/massa fresca (cepas + ramas + raízes $) * 100$.

\subsubsection{Balanço de Massa}

De uma alíquota de $2 \mathrm{~kg}$ de raízes de mandioca por parcela foram separados casca, ponta fibrosa e polpa, suas massas foram medidas e transformadas em porcentagem.

\subsubsection{Teor de amido}

O material foi processado no laboratório de extração de amidos do CERAT (Centro de Raízes e Amidos Tropicais da UNESP/BOTUCATU) obedecendo as seguintes etapas: lavagem de $2 \mathrm{~kg}$ de raiz, descascamento e retirada das pontas fibrosas, desintegração em liquidificador, extração em peneira extratora, após a desintegração e separação do leite de amido, o leite foi colocado para decantar por 12 horas, retirou-se a água sobrenadante. A fécula decantada foi lavada e novamente decantada, então, seca em estufa a $50^{\circ} \mathrm{C}$ durante 24 horas e posteriormente pesada e transformada em porcentagem para determinar o teor de amido das amostras.

\subsubsection{Análise de dados}

Os resultados obtidos foram analisados estatisticamente pelo teste " $F$ " ao nível de 5\% de probabilidade e as médias comparadas pelo teste Tukey ao nível de 5\%. 


\section{RESULTADOS E DISCUSSÃO}

\subsection{Fitotoxicidade sofrida pela plantas de mandioca}

Os sintomas de intoxicação apresentados nos dois ambientes estudados são apresentados em duas Tabelas distintas. A primeira refere-se à fitotoxicidade promovida pelas moléculas aplicadas nas plantas de mandioca cultivadas na Fazenda Experimental São Manuel em São Manuel-SP e a segunda refere-se à fitotoxicidade causada pelas moléculas aplicadas nas plantas de mandioca cultivadas na Fazenda Experimental Lageado em Botucatu-SP.

Pode-se observado na Tabela 9 a fitotoxicidade nas plantas de mandioca nos diversos períodos de avaliação, e que aos 10 dias após a emergência das plantas (DAE) todas as moléculas aplicadas em pré-emergência proporcionaram leves injúrias em ambas variedades testadas. No entanto, somente as moléculas quizalofop-p-ethyl em ambas as variedades e sethoxidim na IAC576-70 não proporcionaram sintomas às plantas das variedades estudadas com aplicação em pós-emergência. Todas as demais moléculas aplicadas proporcionaram algum sintoma de fitotoxicidade às plantas de mandioca, sendo que a molécula fomezafen foi a mais fitotóxica em ambas variedades. Aos 17 DAE, além do fomezafen, a molécula bentazon incrementou os sintomas, demonstrando maiores fitotoxicidade às plantas nesse período, sendo que nos demais tratamentos ocorreu pequeno incremento das injúrias em pré e pós-emergentes não ultrapassando $10 \%$. Pode ser observado também que os herbicida quizalofop-p-ethyl e sethoxidim proporcionaram sintomas visuais de fito às plantas de mandioca, neste período de avaliação.

Aos 22 DAE as injúrias aumentaram na variedade IAC576-70 que recebeu aplicação de atrazine em pré-emergência. No restante dos tratamentos, os sintomas começaram a 
diminuir e desaparecer. Nas plantas tratadas em pós-emergência, observa-se uma pequena redução dos danos causados e somente a molécula fomezafen aplicado na variedade IAC576-70 apresentou uma redução acentuada das injurias. Aos 29 DAE apenas algumas pequenas injúrias permaneceram, porém a molécula de atrazine ainda proporciona maior injúria em relação às outras moléculas em pré-emergência. Nas moléculas com aplicação em pós-emergência as injúrias começaram a desaparecer, porém ainda eram elevadas para o bentazon e o fomezafen em ambas as cultivares.

Entretanto aos $39 \mathrm{DAE}$ todas as parcelas que receberam tratamentos independente da época de aplicação apresentam pequenas injúrias e aos 49 DAE os tratamentos já não causavam danos visuais às plantas, sendo que somente as moléculas bentazon e fomezafen causaram danos preocupantes as plantas tratadas até 29 DAE. Entretanto, as plantas da cultura obtiveram uma recuperação rápida, sendo que nos outros tratamentos os sintomas observados em todas as avaliações podem ser considerados leves e aceitáveis.

Verifica-se na Tabela 10 as avaliações de fitointoxicação nos diversos períodos de avaliação em Botucatu-SP. Nota-se que aos 12 dias após a emergência das plantas (DAE) que todas as moléculas aplicadas em pré-emergência proporcionaram leves injúrias as plantas de mandioca das variedades IAC14 e IAC576-70 e somente as moléculas fomezafen e bentazon proporcionaram leves injurias as plantas de mandioca quando aplicado em pósemergência.

Aos 19 DAE somente as plantas da variedade IAC14 tratadas com a molécula haloxyfof-methyl não apresentava sintomas. No restante dos tratamentos ocorreram pequenos incrementos das injúrias em pré e pós-emergentes não ultrapassando $10 \%$. Na avaliação ocorrida aos 26 DAE, observa-se que, praticamente, todos os tratamentos aplicados em préemergência não causavam nenhuma fitointoxicação às plantas de ambas as variedades estudadas, sendo que os sintomas observados em todas as avaliações podem ser considerados leves e aceitáveis. Observa-se que os sintomas têm maior persistência na variedade IAC-14, porém quando avaliadas as injurias em pós-emergência verifica-se que a molécula sethoxidim causou pequenos danos a cultura. No entanto, as moléculas bentazon e fomezafen aumentaram drasticamente os sintomas de fitointoxicação, causando danos consideráveis as plantas. Observa-se assim como no ensaio realizado em São Manuel, que os danos são maiores na variedade IAC14.

As moléculas aplicadas em pré-emergência não causam danos às plantas aos 33 DAE. Apenas sethoxidim aplicado em pós-emergência na variedade IAC576-70 teve pequeno incremento nas injurias causadas. As plantas do tratamento que receberam a aplicação de fomezafen 
tiveram redução dos sintomas de fitointoxicação, ao contrário do bentazon que diminuiu os danos causados.

Tabela 9. Fitotoxicidade de herbicidas aplicados em pré e pós-emergência na cultura da mandioca nas variedades IAC14 e IAC576-70 em diferentes períodos de avaliação na Fazenda Experimental São Manuel em São Manuel-SP.

\begin{tabular}{|c|c|c|c|c|c|c|c|}
\hline \multirow{6}{*}{ TRATAMENTOS } & \multicolumn{7}{|c|}{ Fitotoxicidade \% } \\
\hline & \multicolumn{7}{|c|}{ Dias após a emergência } \\
\hline & & 10 & 17 & 22 & 29 & 39 & 49 \\
\hline & \multicolumn{7}{|c|}{ Dias após a aplicação } \\
\hline & Pós & 2 & 7 & 12 & 19 & 29 & 39 \\
\hline & Pré & 29 & 36 & 41 & 48 & 59 & 69 \\
\hline ametryne + IAC14 & Pré & 8 & 10 & 4 & 3 & 1 & 1 \\
\hline ametryne $+576-70$ & Pré & 8 & 9 & 3 & 1 & 0 & 0 \\
\hline clomazone+ IAC14 & Pré & 4 & 7 & 2 & 1 & 1 & 0 \\
\hline clomazone+ IAC576-70 & Pré & 3 & 5 & 1 & 1 & 0 & 0 \\
\hline ametryne + clomazone + IAC14 & Pré & 1 & 7 & 4 & 1 & 1 & 0 \\
\hline ametryne + clomazone + IAC576-70 & Pré & 4 & 3 & 0 & 0 & 0 & 0 \\
\hline atrazine + IAC14 & Pré & 10 & 14 & 13 & 10 & 2 & 5 \\
\hline atrazine + IAC576-70 & Pré & 10 & 9 & 17 & 7 & 0 & 2 \\
\hline haloxyfof-methyl + IAC14 & Pós & 2 & 5 & 4 & 3 & 1 & 0 \\
\hline haloxyfof-methyl + IAC576-70 & Pós & 1 & 2 & 5 & 2 & 0 & 0 \\
\hline sethoxidim + IACIAC14 & Pós & 2 & 1 & 3 & 2 & 1 & 0 \\
\hline sethoxidim + IAC576-70 & Pós & 0 & 1 & 2 & 2 & 0 & 0 \\
\hline fluazifop-P-butil + IAC14 & Pós & 3 & 4 & 3 & 2 & 0 & 0 \\
\hline fluazifop-P-butil + IAC576-70 & Pós & 4 & 5 & 4 & 3 & 0 & 0 \\
\hline quizalofop-P-ethyl + IAC14 & Pós & 0 & 3 & 4 & 2 & 1 & 0 \\
\hline quizalofop-P-ethyl + IAC576-70 & Pós & 0 & 1 & 2 & 2 & 0 & 0 \\
\hline fomezafen + IAC14 & Pós & 39 & 46 & 39 & 29 & 2 & 2 \\
\hline fomezafen + IAC576-70 & Pós & 33 & 38 & 18 & 11 & 1 & 0 \\
\hline bentazon + IAC14 & Pós & 5 & 56 & 49 & 37 & 1 & 1 \\
\hline bentazon + IAC576-70 & Pós & 5 & 57 & 39 & 33 & 3 & 1 \\
\hline testemunha capinada + IAC14 & --- & 0 & 0 & 0 & 0 & 0 & 0 \\
\hline testemunha capinada + IAC576-70 & ---- & 0 & 0 & 0 & 0 & 0 & 0 \\
\hline
\end{tabular}


Tabela 10. Fitotoxicidade de herbicidas aplicados em pré e pós-emergência na cultura da mandioca nas variedades IAC14 e IAC576-70 em diferentes períodos de avaliação na Fazenda Experimental Lageado em Botucatu-SP.

\begin{tabular}{|c|c|c|c|c|c|c|c|}
\hline \multirow{6}{*}{ TRATAMENTOS } & \multicolumn{7}{|c|}{ Fitotoxicidade \% } \\
\hline & \multicolumn{7}{|c|}{ Dias após a emergência } \\
\hline & & 12 & 19 & 26 & 33 & 40 & 47 \\
\hline & \multicolumn{7}{|c|}{ Dias após a aplicação } \\
\hline & Pós & 2 & 7 & 14 & 21 & 28 & 35 \\
\hline & Pré & 33 & 39 & 47 & 54 & 61 & 69 \\
\hline ametryne + IAC14 & Pré & 3 & 4 & 0 & 0 & 0 & 0 \\
\hline ametryne $+576-70$ & Pré & 2 & 3 & 0 & 0 & 0 & 0 \\
\hline clomazone+ IAC14 & Pré & 2 & 5 & 0 & 0 & 0 & 0 \\
\hline clomazone+ IAC576-70 & Pré & 2 & 1 & 0 & 0 & 0 & 0 \\
\hline ametryne + clomazone + IAC14 & Pré & 1 & 4 & 1 & 1 & 0 & 0 \\
\hline ametryne + clomazone + IAC576-70 & Pré & 2 & 2 & 0 & 0 & 0 & 0 \\
\hline atrazine + IAC14 & Pré & 6 & 5 & 1 & 1 & 0 & 0 \\
\hline atrazine + IAC576-70 & Pré & 3 & 3 & 0 & 0 & 0 & 0 \\
\hline haloxyfof-methyl + IAC14 & Pós & 0 & 0 & 0 & 0 & 0 & 0 \\
\hline haloxyfof-methyl + IAC576-70 & Pós & 0 & 1 & 2 & 1 & 0 & 0 \\
\hline sethoxidim + IACIAC14 & Pós & 0 & 1 & 5 & 7 & 1 & 0 \\
\hline sethoxidim + IAC576-70 & Pós & 0 & 1 & 10 & 15 & 3 & 0 \\
\hline fluazifop-P-butil + IAC14 & Pós & 0 & 1 & 0 & 0 & 0 & 0 \\
\hline fluazifop-P-butil + IAC576-70 & Pós & 0 & 1 & 0 & 0 & 0 & 0 \\
\hline quizalofop-P-ethyl + IAC14 & Pós & 0 & 2 & 0 & 0 & 0 & 0 \\
\hline quizalofop-P-ethyl + IAC576-70 & Pós & 0 & 0 & 1 & 2 & 1 & 0 \\
\hline fomezafen + IAC14 & Pós & 5 & 13 & 26 & 22 & 8 & 0 \\
\hline fomezafen + IAC576-70 & Pós & 3 & 6 & 17 & 19 & 4 & 0 \\
\hline bentazon + IAC14 & Pós & 3 & 9 & 54 & 18 & 2 & 0 \\
\hline bentazon + IAC576-70 & Pós & 7 & 10 & 45 & 7 & 0 & 0 \\
\hline testemunha capinada + IAC14 & ---- & 0 & 0 & 0 & 0 & 0 & 0 \\
\hline testemunha capinada + IAC576-70 & ---- & 0 & 0 & 0 & 0 & 0 & 0 \\
\hline
\end{tabular}

Aos 40 DAE, a maioria dos tratamentos já não causavam danos visíveis às plantas, sendo que somente as moléculas sethoxidim, quizalofop, bentazon e fomezafen em pós emergência causaram danos leves as plantas tratadas, com recuperação rápida dos danos causados Neste caso, somente as moléculas bentazon e fomezafen aplicadas em pós-emergência causaram injurias drásticas às plantas da cultura e obtiveram, também, recuperação rápida. Os danos causados por essas moléculas foram menos drásticos nas plantas da variedades IAC576-70. 
A recuperação das plantas dos tratamentos em que foram aplicadas moléculas de herbicidas em pré-emergência na Fazenda Lageado, foi mais rápida do que na Fazenda Experimental São Manuel. O mesmo não foi observado nas moléculas aplicadas em pósemergência.

\subsection{Características da parte aérea da planta}

Os resultados da análise de variância feita para as características da parte aérea da planta nas Fazendas Experimentais São Manuel e Lageado encontram-se resumidos nas Tabelas 11 e 12, respectivamente, onde são apresentados os valores de F para as causas de variação e sua interação, e o desdobramento dos graus de liberdade. Nas Tabelas, encontram-se os resultados de altura das plantas (AP), altura da primeira ramificação (AR), diâmetro do caule (DC), número de plantas por hectare $(\mathrm{P})$, número de hastes médio por planta $(\mathrm{H})$, produtividade da parte aérea da planta (PA), produtividade da matéria seca da parte aérea (MS PA), porcentagem de matéria seca da parte aérea (\% MS PA).

Tabela 11. Resumo da análise de variância com valores de F calculados para as causas de variação e sua interação e médias para as características da parte aérea da planta, altura das plantas $(\mathrm{cm})(\mathrm{AP})$, altura da primeira ramificação $(\mathrm{cm})(\mathrm{AR})$, diâmetro do caule $(\mathrm{cm})(\mathrm{DC})$, número de plantas por hectare $(\mathrm{P})$, número de hastes médio por planta $(\mathrm{H})$, produtividade de parte aérea da planta $\left(\mathrm{t} \mathrm{ha}^{-1}\right)(\mathrm{PA})$, produtividade da matéria seca da parte aérea $\left(\mathrm{t} \mathrm{ha}^{-1}\right)$ (MS PA), porcentagem de matéria seca da parte aérea (MS PA), na Fazenda Experimental São Manuel, São Manuel - SP, 2009.

\begin{tabular}{lcccccccc}
\hline \multicolumn{1}{c}{$\begin{array}{c}\text { Causas da } \\
\text { variação }\end{array}$} & AP & AR & DC & P & H & PA & MS PA & \% MS PA \\
\hline BLOCO & $7,84^{* *}$ & $3,33^{* *}$ & $3,80^{* *}$ & $0,03^{* *}$ & $0.92 \mathrm{~ns}$ & $16,02^{* *}$ & $16,54^{* *}$ & $6,09^{* *}$ \\
HERBICIDA (H) & $1,12 \mathrm{~ns}$ & $0,89 \mathrm{~ns}$ & $3,56^{* *}$ & $1,12 \mathrm{~ns}$ & $5,43 \mathrm{~ns}$ & $2,57^{* *}$ & $2,81^{* *}$ & $1,16 \mathrm{~ns}$ \\
VARIEDADE (V) & $79,44^{* *}$ & $6,35^{* *}$ & $1,62 \mathrm{~ns}$ & $4,74^{* *}$ & $3,81 \mathrm{~ns}$ & $24,38^{* *}$ & $24,34^{* *}$ & $3,47 \mathrm{~ns}$ \\
V X H & $1,00 \mathrm{~ns}$ & $1,01 \mathrm{~ns}$ & $1,55 \mathrm{~ns}$ & $0,80 \mathrm{~ns}$ & $0,87 \mathrm{~ns}$ & $1,45 \mathrm{~ns}$ & $1,06 \mathrm{~ns}$ & $1,02 \mathrm{~ns}$ \\
\hline Média & $--1,-$ \\
C.V (\%) & 135,54 & 40,45 & 1,97 & 12286,95 & 2,04 & 7,58 & 2,63 & 33,64 \\
\hline & 17,27 & 42,60 & 17,74 & 6,23 & 20,80 & 50,8 & 55,55 & 10,04 \\
\hline
\end{tabular}

NS: não significativo $(\mathrm{P}>0,05) *: \mathrm{P}<0,05 ; \mathrm{P}<0,01$. 
Tabela 12. Resumo da análise de variância com valores de F calculados para as causas de variação e sua interação e médias para as características da parte aérea da planta altura das plantas em $(\mathrm{cm})(\mathrm{AP})$, altura da primeira ramificação em $(\mathrm{cm})(\mathrm{AR})$, diâmetro do caule em $(\mathrm{cm})$ $(\mathrm{DC})$, número de plantas por hectare $(\mathrm{P})$, número de hastes médio por planta $(\mathrm{H})$, produtividade de parte aérea da planta em $\left(\mathrm{t} \mathrm{ha}^{-1}\right)(\mathrm{PA})$, produtividade da matéria seca da parte aérea em ( $\mathrm{t} \mathrm{ha}^{-1}$ ) (MS PA), porcentagem de matéria seca da parte aérea (MS PA), na Fazenda Experimental Lageado, Botucatu-SP, 2009.

\begin{tabular}{|c|c|c|c|c|c|c|c|c|}
\hline $\begin{array}{c}\text { Causas da } \\
\text { variação }\end{array}$ & AP & AR & DC & $\mathbf{P}$ & $\mathbf{H}$ & PA & MS PA & $\begin{array}{c}\% \text { MS } \\
\text { PA }\end{array}$ \\
\hline BLOCO & $18,64 * *$ & $0,81 \mathrm{~ns}$ & $0,55 \mathrm{~ns}$ & $1,78 \mathrm{~ns}$ & $0,96 \mathrm{~ns}$ & $10,14 * *$ & $8,79 * *$ & $2,60 \mathrm{~ns}$ \\
\hline HERBICIDA (H) & $3,26 * *$ & $1,96 \mathrm{~ns}$ & $1,09 \mathrm{~ns}$ & $2,23 * *$ & $1,62 \mathrm{~ns}$ & $5,44 * *$ & $3,65 * *$ & $0,74 \mathrm{~ns}$ \\
\hline VARIEDADE (V) & $82,24 * *$ & $82,07 * *$ & $1,46 \mathrm{~ns}$ & $45,30 * *$ & $3,80 \mathrm{~ns}$ & $47,34 * *$ & $32,55 * *$ & $0,03 \mathrm{~ns}$ \\
\hline$\underline{\mathbf{V}} \underset{\mathbf{X}}{\mathbf{H}}$ & $1,93 \mathrm{~ns}$ & $2,21 * *$ & $1,24 \mathrm{~ns}$ & $1,54 \mathrm{~ns}$ & $0,87 \mathrm{~ns}$ & $1,33 \mathrm{~ns}$ & $2,18 * *$ & $1,40 \mathrm{~ns}$ \\
\hline Média & 135,82 & 48,24 & 2,1 & 10058,7 & 2,01 & 4,62 & 1,42 & 30,28 \\
\hline C.V (\%) & 13,57 & 18,92 & 82,08 & 16,11 & 18,96 & 36,27 & 42,84 & 23,73 \\
\hline
\end{tabular}

NS: não significativo $(\mathrm{P}>0,05)$ **: $\mathrm{P}<0,05 ; \mathrm{P}<0,01$.

\subsubsection{Altura das plantas}

A interação dos fatores herbicida e variedades na Fazenda Experimental São Manuel não influenciaram significativamente na altura das plantas, tão pouco, o fator herbicida. No entanto, quanto ao fator variedade apresenta significância. Na Fazenda Experimental Lageado a interação dos fatores herbicidas e variedades não influem significativamente na altura de plantas. No entanto, quando avaliados os fatores separadamente apresentam significância estatística. Os efeitos dos herbicidas na altura das plantas de ambas as variedades, nas Fazendas Experimentais São Manuel e Lageado estão representados nas Tabelas 13 e 14.

Na Tabela 13, verifica-se que existe comportamento diferente em relação às variedades na Fazenda Experimental São Manuel. A variedade IAC14 tem crescimento mais rápido e maior altura em relação a IAC576-70, percebe-se que na aplicação da maioria dos herbicidas as plantas da variedade IAC14 obteve maior altura final das plantas, sendo que as moléculas clomazone, fomezafen e a testemunha não diferem entre as variedades independente do tratamento. No entanto, a altura das plantas da variedade IAC14 são maiores que a da IAC576-70. Verifica-se que não houve efeito dos herbicidas aplicados dentro de cada variedade. 
Tabela 13. Altura das plantas $(\mathrm{cm})$ das variedades IAC14 e IAC576-70, Fazenda Experimental São Manuel, São Manuel - SP, 2009.

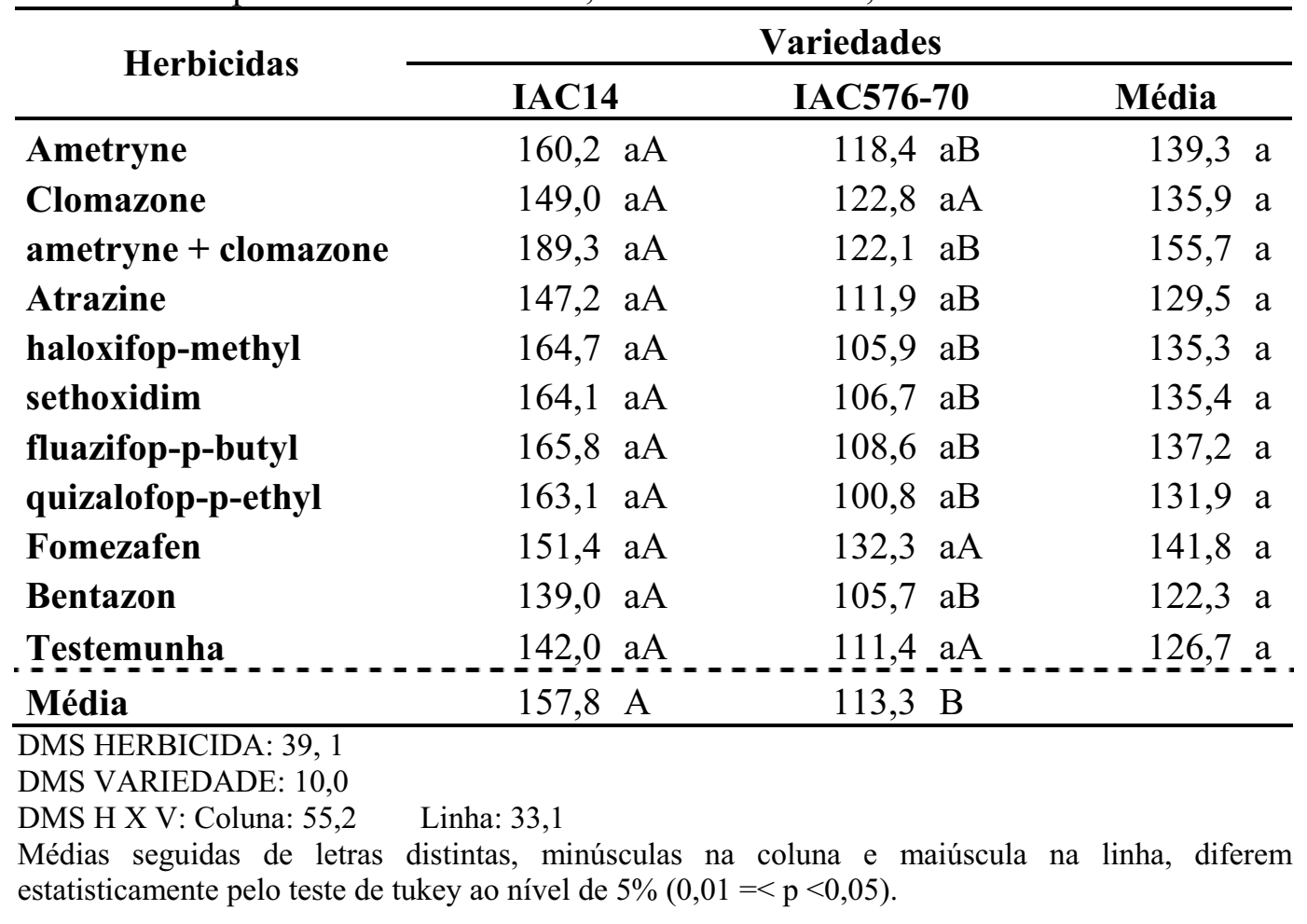

A mistura ametryne + clomazone aplicada em pré-emergência proporcionou maior desenvolvimento em altura das plantas de mandioca da variedade IAC14 e a molécula bentazon ocasionou o menor desenvolvimento em altura. A molécula bentazon foi uma das moléculas que mais causaram injurias nas folhas das plantas no inicio do ciclo, Tabelas 9 e 10 . Quando aplicada a molécula fomezafen em pós-emergência na variedade IAC576-70 é observada maior altura das plantas e menor altura quando da aplicação da molécula bentazon. As moléculas bentazon e fomezafen foram as que causaram maiores injurias visuais as plantas de mandioca independente do ambiente que a cultura estava inserida. No entanto, para o parâmetro altura das plantas observa-se que as plantas da variedade IAC576-70, quando aplicada a molécula fomezafem, tiveram recuperação rápida. Apesar de algumas moléculas em ambas as variedades possibilitarem maior altura das plantas não há efeito das moléculas dos herbicidas na altura das plantas.

Na Tabela 14, a variedade IAC14 se comporta de maneira diferente em relação a altura das plantas entre as variedades estudadas na Fazenda Experimental Lageado. A variedade IAC14 por ter hábito de crescimento mais rápido e maior estatura em relação a IAC57670, obteve maior estatura final das plantas. No entanto são observadas diferenças estatísticas significativas, dessa forma a variedade teve resposta diferentes aos herbicidas aplicados. Na 
variedade IAC576-70 não houve diferenças estatísticas significativas independente da molécula aplicada. Em ambas as variedades a molécula bentazon aplicada em pós-emergência causou maiores danos a altura das plantas e a mistura ametryne + clomazone aplicada em pré-emergência foi que menos interferiu na altura das plantas. Observa também que independente da variedade as moléculas clomazone e a mistura ametryne + clomazone foram as que menos danos causaram a altura das plantas, da mesma forma a molécula bentazon, no entanto, foi o herbicida que causou maior dano em ambas as variedades.

Tabela 14. Altura das plantas $(\mathrm{cm})$ das variedades IAC14 e IAC576-70, Fazenda Experimental Lageado, Botucatu - SP, 2009.

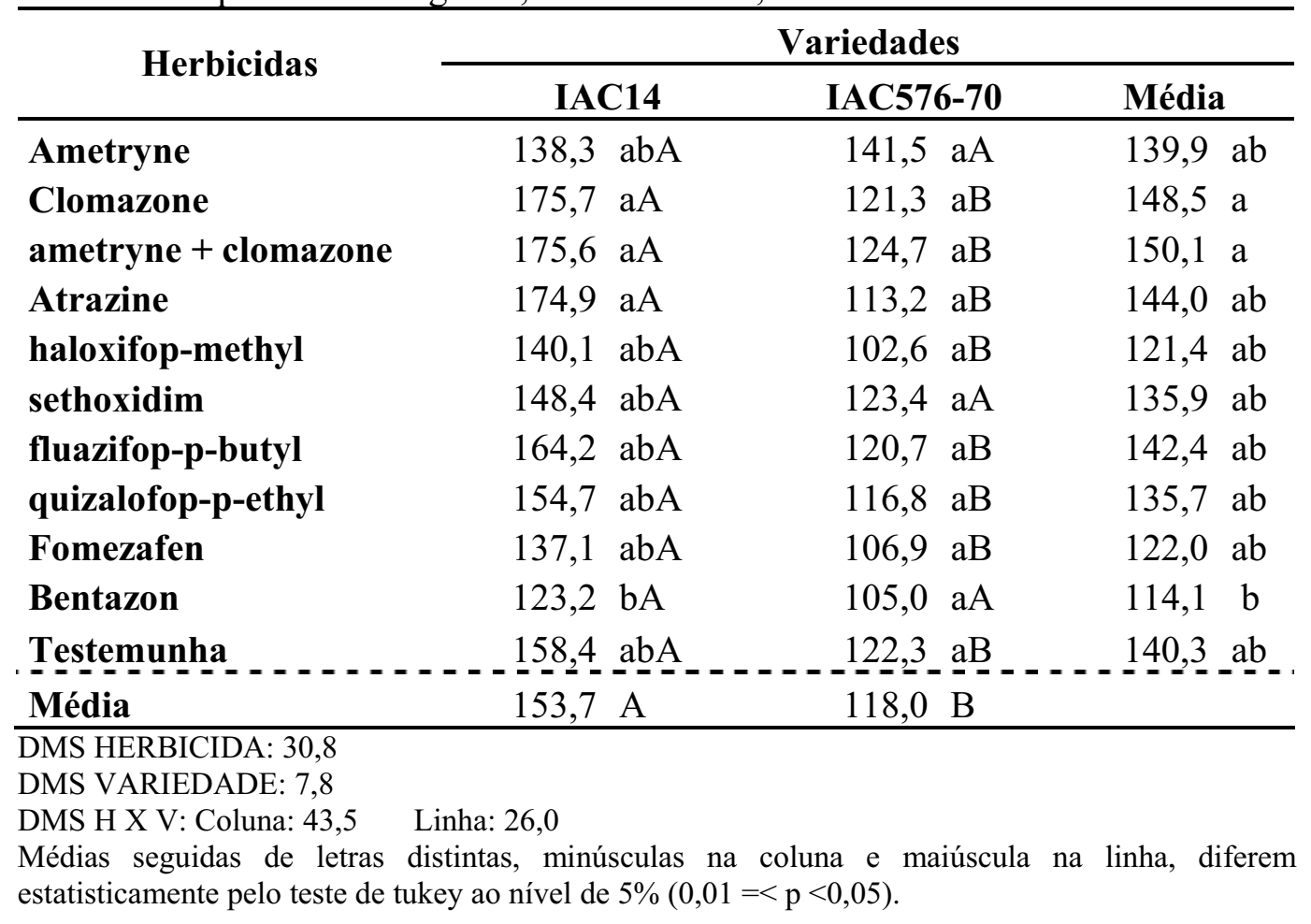

\subsubsection{Altura primeira ramificação}

Não houve interação dos fatores herbicida e variedades no experimento realizado na Fazenda Experimental São Manuel para o parâmetro altura da primeira ramificação das plantas, assim como para o fator herbicida. O fator variedade apresenta significância estatística. No experimento realizado na Fazenda Experimental Lageado o fator herbicida não influenciou significativamente na altura da primeira ramificação. No entanto, o fator variedade e a interação dos fatores herbicidas e variedades apresentam significância. Os efeitos dos herbicidas na altura da 
primeira ramificação das plantas de ambas as variedades, nas Fazendas Experimentais São Manuel e Lageado estão representados nas Tabelas 15 e 16, respectivamente.

$\mathrm{Na}$ Tabela 15, observa-se que a altura da primeira ramificação das variedades IAC14 e IAC576-70 não foi influenciada pelo herbicida aplicado estatisticamente. Entretanto, a molécula haloxifop-methyl proporcionou a maior altura da primeira ramificação e clomazone, a menor altura quando aplicada na variedade IAC14 e a ametryne aplicada em préemergência maior altura da primeira ramificação na variedade IAC576-70 e fomezafen a menor. Sendo que na variedade IAC14 a maior altura da primeira ramificação, observa-se que independente da variedade na qual o herbicida é aplicado não há influência dos mesmos.

Tabela 15. Altura da primeira ramificação das plantas $(\mathrm{cm})$ das variedades IAC14 e IAC576-70, Fazenda Experimental São Manuel, São Manuel - SP, 2009.

\begin{tabular}{|c|c|c|c|}
\hline \multirow{2}{*}{ Herbicidas } & \multicolumn{3}{|c|}{ Variedades } \\
\hline & IAC14 & IAC576-70 & Média \\
\hline Ametryne & 40,0 aA & 59,8 aA & 49,9 a \\
\hline Clomazone & 39,1 aA & 30,4 aA & 34,8 a \\
\hline ametryne + clomazone & 46,3 aA & 31,3 aA & 38,8 a \\
\hline Atrazine & $49,5 \mathrm{aA}$ & 39,3 aA & 44,4 a \\
\hline haloxifop-methyl & $67,4 \mathrm{aA}$ & $36,0 \mathrm{aB}$ & 51,7 a \\
\hline sethoxidim & $46,3 \mathrm{aA}$ & 28,9 aA & 37,6 a \\
\hline fluazifop-p-butyl & 41,3 aA & 34,5 aA & 37,9 a \\
\hline quizalofop-p-ethyl & 41,7 aA & 32,6 aA & 37,1 a \\
\hline Fomezafen & 41,9 aA & 28,8 aA & 35,4 a \\
\hline Bentazon & 42,0 aA & 39,0 aA & $40,5 \mathrm{a}$ \\
\hline Testemunha & 40,6 aA & 33,7 aA & 37,2 a \\
\hline Média & $45,1 \quad \mathrm{~A}$ & $35,8 \mathrm{~B}$ & \\
\hline
\end{tabular}

DMS HERBICIDA: 28,7

DMS VARIEDADE: 7,3

DMS H X V: Coluna: $40,7 \quad$ Linha: 24,4

Médias seguidas de letras distintas, minúsculas na coluna e maiúscula na linha, diferem estatisticamente pelo teste de tukey ao nível de $5 \%(0,01=<\mathrm{p}<0,05)$.

$\mathrm{Na}$ Tabela 16, observa-se diferenças estatísticas significativas dos herbicidas aplicados na variedade IAC14 para o parâmetro altura da primeira ramificação. A molécula bentazon proporcionou menor altura da primeira ramificação e a clomazone maior altura. A variedade IAC576-70, no entanto, não é influenciada por nenhuma das moléculas aplicadas, sendo que a testemunha sem aplicação proporcionou maior altura da primeira ramificação e a molécula sethoxidim a menor altura. A variedade IAC14 independente do herbicida aplicado tem a altura da 
primeira ramificação maior. As variedades responderam de forma diferente a aplicação dos herbicidas, a variedade IAC576-70 se mostrou mais seletiva aos herbicidas para o fator altura da primeira ramificação.

Tabela 16. Altura da primeira ramificação das plantas $(\mathrm{cm})$ das variedades IAC14 e IAC576-70, Fazenda Experimental Lageado, Botucatu - SP, 2009.

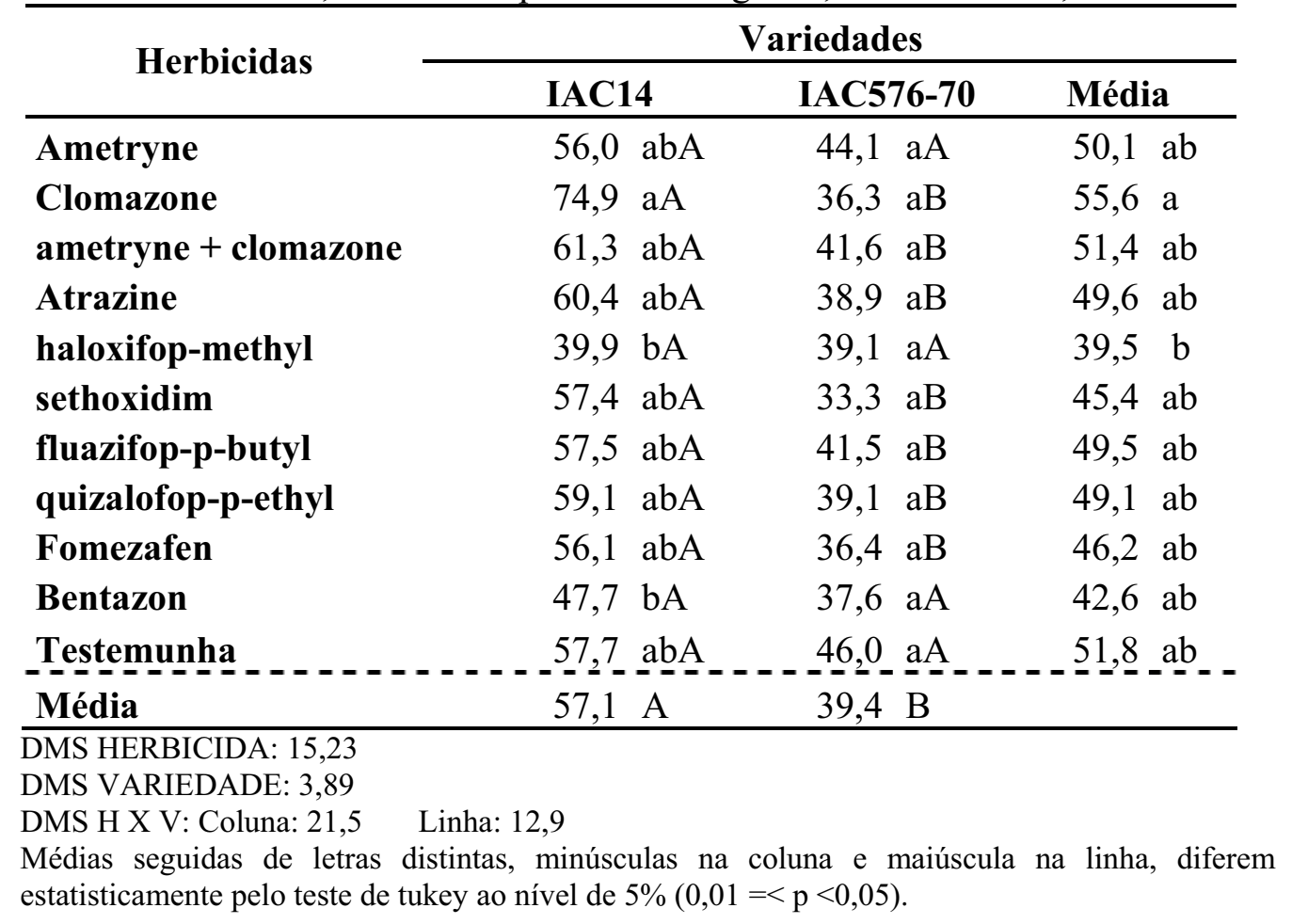

\subsubsection{Diâmetro do caule}

A interação dos fatores herbicida e variedades na Fazenda Experimental São Manuel não influem significativamente o diâmetro do caule, mesmo comportamento teve o fator variedade. No entanto, quanto ao fator herbicida apresenta significância. Na Fazenda Experimental Lageado o fatores analisados não influem significativamente o diâmetro do caule. Os efeitos dos herbicidas no diâmetro dos caules de ambas as variedades, na Fazenda Experimental São Manuel está representado na Tabela 17.

Observa-se na Tabela 17, que houve diferença estatística significativa no diâmetro do caule das plantas da variedade IAC14. Todavia, quando aplicada à molécula fomezafen o diâmetro é maior e na testemunha sem aplicação menor diâmetro, alertando para efeito do herbicida no engrossamento do caule. Não houve diferença estatística significativa na variedade IAC576-70 para o parâmetro diâmetro do caule. Porém na aplicação da molécula ametryne observa- 
se maior diâmetro e menor na molécula quizalofop-p-ethyl. Não há diferença na média entre as variedades, sendo que as plantas responderam de forma diferente a aplicação dos herbicidas. Entretanto nota-se que a há diferenças entre a molécula fomezafen e as moléculas atrazine, sethoxidim , quizalofop-p-ethyl, bentazon e a testemunha e o restante das moléculas não diferindo entre si.

Tabela 17. Diâmetro do caule $(\mathrm{cm})$ das plantas das variedades IAC14 e IAC576-70, Fazenda Experimental São Manuel, São Manuel - SP, 2009.

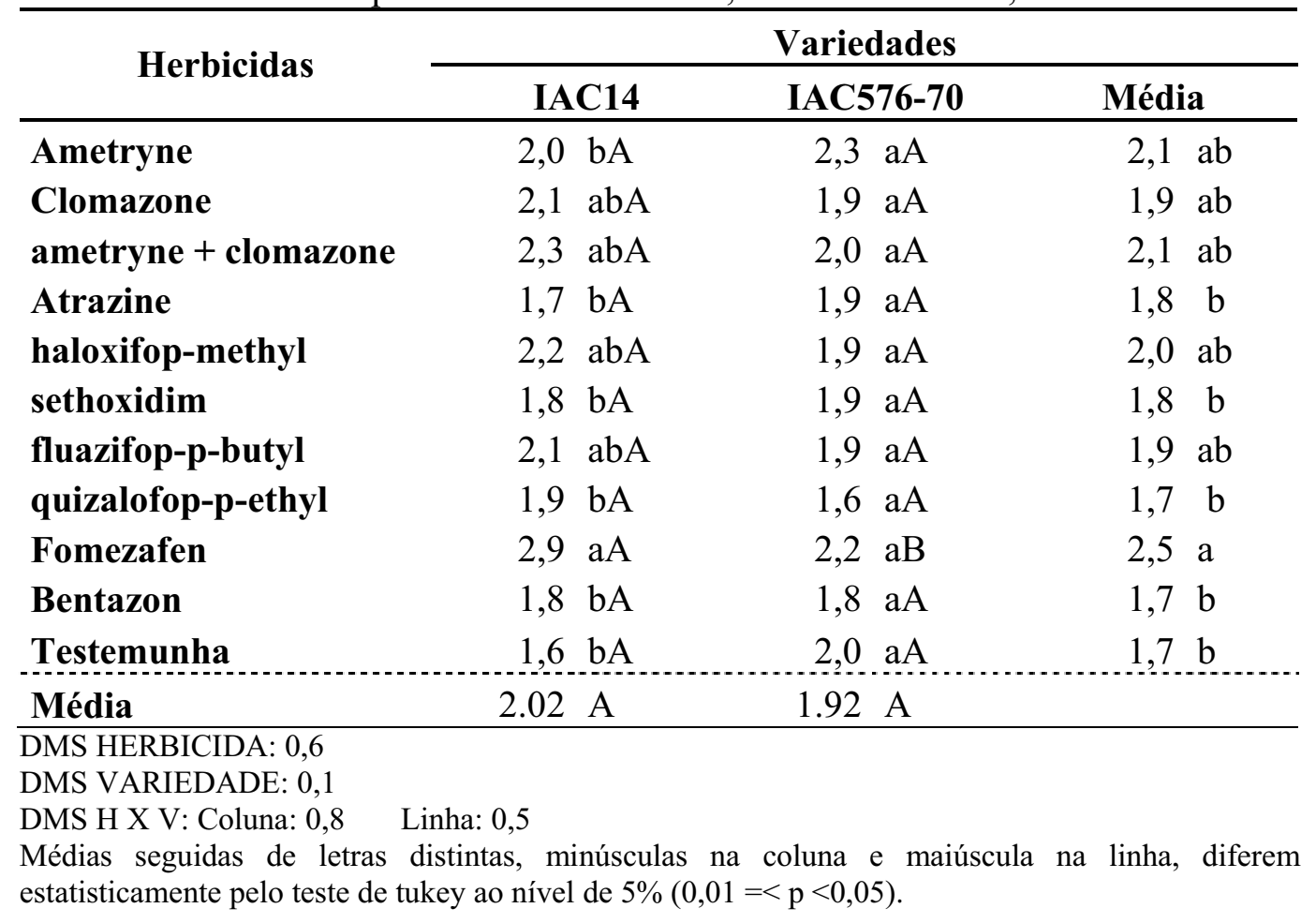

\subsubsection{Número de plantas por hectare}

As interações dos fatores herbicidas e variedades na Fazenda Experimental São Manuel não influem significativamente o número de plantas por hectare, tão pouco, o fator herbicida. No entanto, quanto ao fator variedade apresenta significância. Na Fazenda Experimental Lageado a interação dos fatores herbicidas e variedades não influíram significativamente o número de plantas, sendo que os fatores herbicidas e variedades analisadas separadamente apresentaram significância. Os efeitos dos herbicidas no número de plantas por hectare de ambas as variedades, na Fazenda Experimental São Manuel e Lageado estão representados na Tabelas 18 e 19, respectivamente.

Na Tabela 18, verifica-se que dentro de cada variedade não houve influencia do herbicida para o parâmetro número de plantas por hectare, sendo que a variedade IAC14 
apresenta maior número que a IAC576-70. Dentro dos herbicidas as moléculas ametryne e sethoxidim aplicadas na variedade IAC5760-70 menor número de plantas da cultura por hectare.

Tabela 18. Número de plantas por hectare no final do ciclo das variedades IAC14 e IAC576-70, Fazenda Experimental São Manuel, São Manuel - SP, 2009.

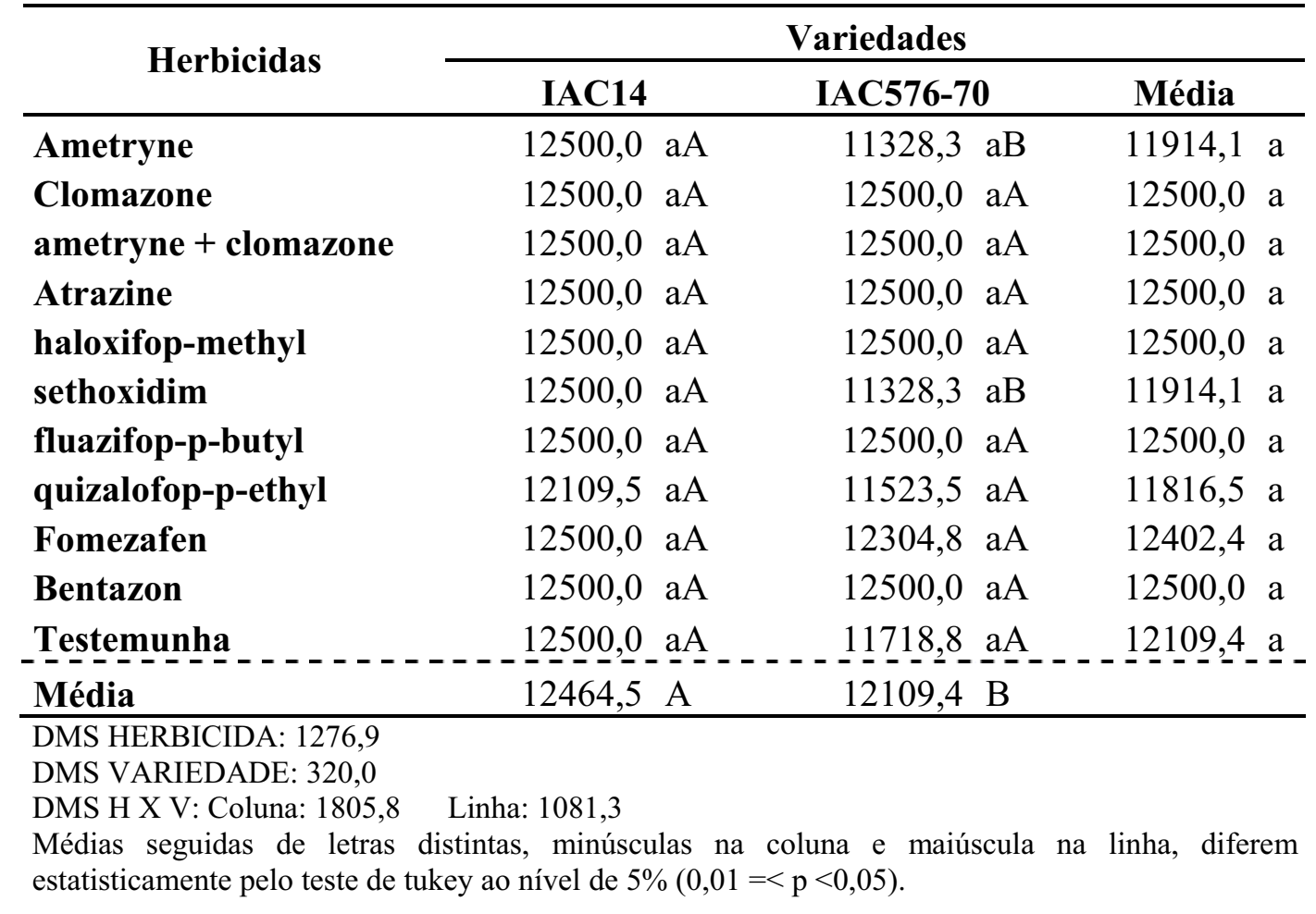

Há diferença na média de plantas por hectare das variedades IAC14 e IAC576-70. Todavia, alguns tratamentos tem menor número de plantas por hectare. Esse menor número de plantas por hectare não pode ser atribuído às moléculas de herbicidas aplicadas, pois nenhum dos herbicidas aplicados proporcionaram injurias que levassem as plantas à morte. Esse menor número de plantas por hectare pode estar relacionado com a brotação das plantas e com as operações manutenção das parcelas em relação às plantas daninhas, já que o referido trabalho tem o objetivo de avaliar a seletividade dos herbicidas à planta de mandioca e não a eficiência dos mesmos em relação às plantas daninhas. Foram realizadas capinas durante a realização do estudo para que não houvesse competição que levasse a uma interpretação equivocada. No entanto, essas capinas proporcionaram danos mecânicos as plantas que as levaram a morte.

Na Tabela 19, verifica-se que ocorreu diferença estatística na população de plantas por hectare na variedade IAC14, sendo o tratamento com a molécula clomazone apresentou maior número de plantas e a testemunha menor número de plantas. As manivas da variedade IAC14 
não brotaram como esperado nesse estudo, com isso levou a prejuízos no número de plantas por hectare, pela grande quantidade de falhas encontradas. Verifica-se que a testemunha obteve menor número de plantas por hectare, e esse fato é atribuído às falhas proporcionadas e também aos danos mecânicos causados durante as capinas na realização do estudo, já que nenhuma molécula de herbicidas causou a morte das plantas de mandioca. Esse parâmetro é fundamental, pois a produção é influenciada pelo número final de plantas no hectare.

Tabela 19. Número de plantas por hectare no final do ciclo das variedades IAC14 e IAC576-70, Fazenda Experimental Lageado, Botucatu - SP, 2009.

\begin{tabular}{lrrr}
\hline \multirow{2}{*}{\multicolumn{1}{c}{ Herbicidas }} & \multicolumn{4}{c}{ Variedades } \\
\cline { 2 - 5 } IAC14 & IAC576-70 & Média \\
\hline Ametryne & $8007,8 \mathrm{abB}$ & $11719,0 \mathrm{aA}$ & $9863,4 \mathrm{ab}$ \\
ametryne + clomazone & $10937,8 \mathrm{aA}$ & $12304,8 \mathrm{aA}$ & $11621,3 \mathrm{a}$ \\
Atrazine & $10547,0 \mathrm{abA}$ & $12109,5 \mathrm{aA}$ & $11328,3 \mathrm{ab}$ \\
haloxifop-methyl & $9179,8 \mathrm{abB}$ & $12109,5 \mathrm{aA}$ & $10644,6 \mathrm{ab}$ \\
sethoxidim & $7812,8 \mathrm{abB}$ & $11523,5 \mathrm{aA}$ & $9668,1 \mathrm{ab}$ \\
fluazifop-p-butyl & $9179,8 \mathrm{abA}$ & $10938,0 \mathrm{aA}$ & $10058,9 \mathrm{ab}$ \\
quizalofop-p-ethyl & $8984,3 \mathrm{abB}$ & $11328,3 \mathrm{aA}$ & $10156,3 \mathrm{ab}$ \\
Fomezafen & $7617,3 \mathrm{abB}$ & $11719,0 \mathrm{aA}$ & $9668,1 \mathrm{ab}$ \\
Bentazon & $9375,0 \mathrm{abA}$ & $9765,5 \mathrm{aA}$ & $9570,3 \mathrm{ab}$ \\
Testemunha & $9375,0 \mathrm{abA}$ & $9375,0 \mathrm{aA}$ & $9375,0 \mathrm{ab}$ \\
Média & $6836,0 \mathrm{bB}$ & 10547,3 & $\mathrm{aA}$ \\
\hline
\end{tabular}

DMS HERBICIDA: 2705,7

DMS VARIEDADE: 690,8

DMS H X V: Coluna: 3826,5 Linha: 2291,2

Médias seguidas de letras distintas, minúsculas na coluna e maiúscula na linha, diferem estatisticamente pelo teste de tukey ao nível de $5 \%(0,01=<p<0,05)$.

Ainda na Tabela 19, observa-se que nenhuma molécula causou danos significativos a variedade IAC576-70, o que proporcionou o maior número de plantas por hectare em relação à variedade IAC14. Quando analisados os herbicidas, observa que a molécula clomazone independente da variedade é a que causa menor dano ao número de plantas por hectare e a testemunha capinada maior dano.

\subsubsection{Número médio de hastes por planta}


As interações dos fatores herbicidas e variedades na Fazenda Experimental São Manuel e Lageado não influíram significativamente o número médio de hastes por planta, tão pouco, os fatores variedades e herbicidas.

\subsubsection{Produtividade da parte aérea}

A interação dos fatores herbicidas e variedades na Fazenda Experimental São Manuel não influíram significativamente à produtividade de parte aérea das plantas. No entanto, os fatores variedade e herbicida apresentaram significância estatística. Da mesma forma na Fazenda Experimental Lageado. Os efeitos dos herbicidas na produtividade de matéria verde em ambas as variedades, na Fazenda Experimental São Manuel e Lageado estão representados na Tabelas 20 e 21 , respectivamente.

Observa-se na Tabela 20, que a mistura das moléculas ametryne e clomazone proporcionou maior produção da parte aérea quando aplicada na variedade IAC14 e clomazone na variedade IAC576-70. A variedade IAC14 foi mais produtiva na parte aérea do que a variedade IAC576-70.

Tabela 20. Produtividade da parte aérea $\left(\mathrm{t} \mathrm{ha}^{-1}\right)$ das plantas das variedades IAC14 e IAC576-70, Fazenda Experimental São Manuel, São Manuel - SP, 2009.

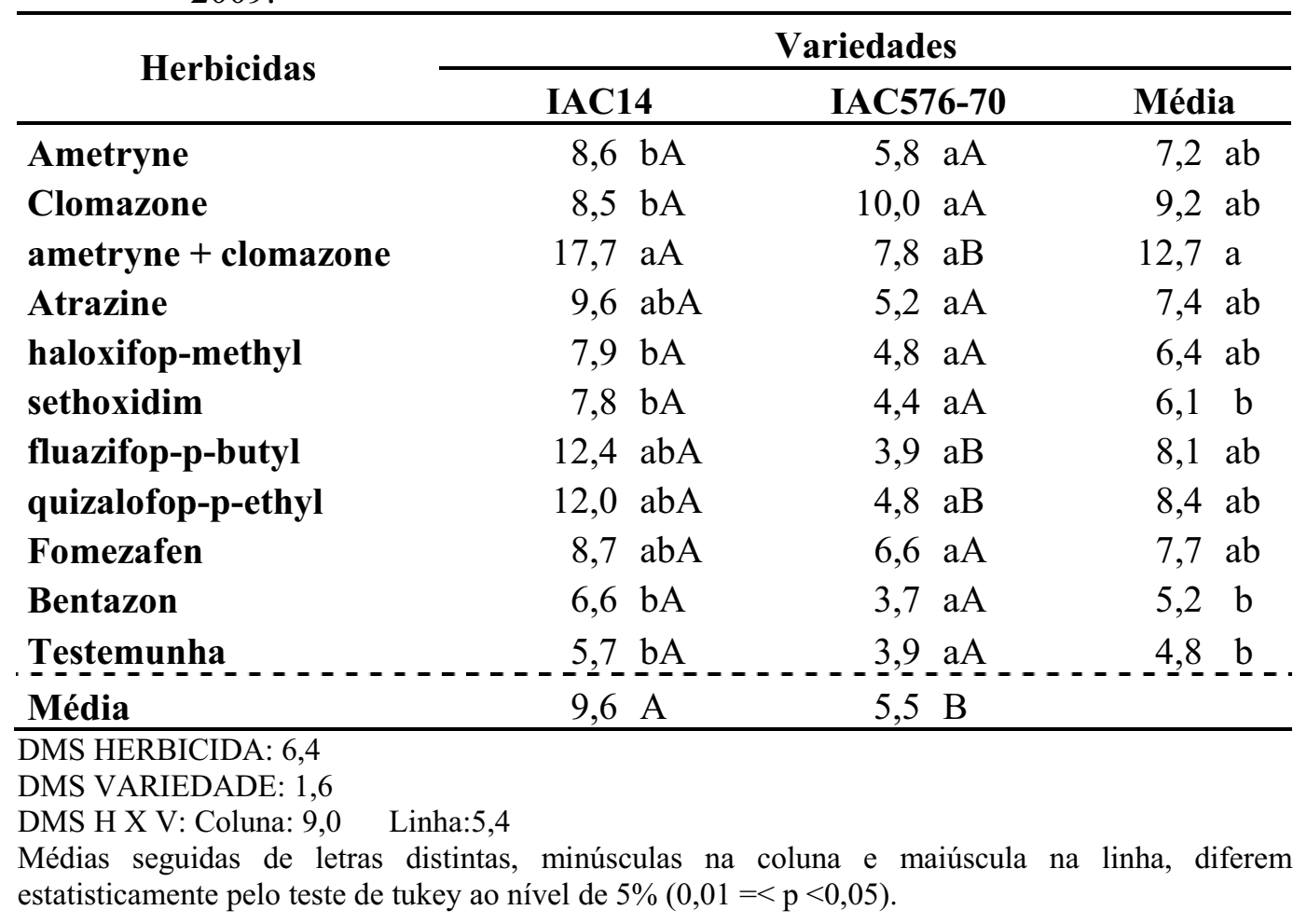


As moléculas fomezafen, bentazon e a testemunha foram as que menos proporcionaram produção de matéria verde em sua parte aérea aplicados na variedade IAC576-70. As moléculas haloxifop-methyl, sethoxidim, bentazon e a testemunha capinada independente da variedade causaram maiores danos à produtividade da matéria verde e a molécula ametryne + clomazone menores danos a esse parâmetro.

No entanto, a produtividade foi baixa em relação ao esperado. Fato esse que pode ser explicado pelas condições climáticas finais que induziram a cultura a entrar em repouso, dessa forma as folhas caíram diminuindo assim a produtividade de matéria verde. De acordo com Montaldo (1979), durante os meses quentes e úmidos, as plantas vegetam de modo abundante, sendo o posterior decréscimo na produção da parte aérea resultado da queda das folhas, fenômeno natural e normal, condicionado pela redução da temperatura e pela escassez de água disponível, conforme Hammer et al. (1987) e Hobman et al. (1987). Variações na produção da parte aérea em razão da época de colheita foram também relatadas por Leonel-Neto (1983), que encontraram maiores valores em períodos de desenvolvimento vegetativo, durante o ciclo cultural, condicionado pelas variações climáticas. A regeneração da estrutura vegetativa na estação de crescimento é comumente observada na mandioca (HAMMER et al., 1987), embora alguns autores tenham relatado não ter havido influência significativa da época de colheita no comportamento de cultivares de mandioca, quanto à produção da parte aérea (FUKUDA \& CALDAS, 1985).

Na Tabela 21, verifica-se que existem diferenças estatísticas significativas entre as moléculas aplicadas na variedade IAC14. A molécula clomazone foi a que proporcionou maior produtividade de matéria verde e a haloxifop-methyl menor produtividade de massa verde da parte aérea. Na variedade IAC576-70 não houve diferença entre os herbicidas aplicados, mesmo assim a variedade IAC14 obteve maior produtividade de matéria verde.

Observa-se que independente da variedade na qual a molécula clomazone foi aplicada, proporciona maior produtividade de matéria verde às plantas e a molécula bentazon a menor produtividade de matéria verde das plantas tratadas. Esse fato é atribuído às injúrias iniciais causadas pela molécula bentazon que resultaram em menor altura final das plantas, diferente da molécula clomazone que causou pequenas injúrias. 
Tabela 21. Produtividade da parte aérea $\left(\mathrm{t} \mathrm{ha}^{-1}\right)$ das plantas das variedades IAC14 e IAC576-70, Fazenda Experimental Lageado, Botucatu - SP, 2009.

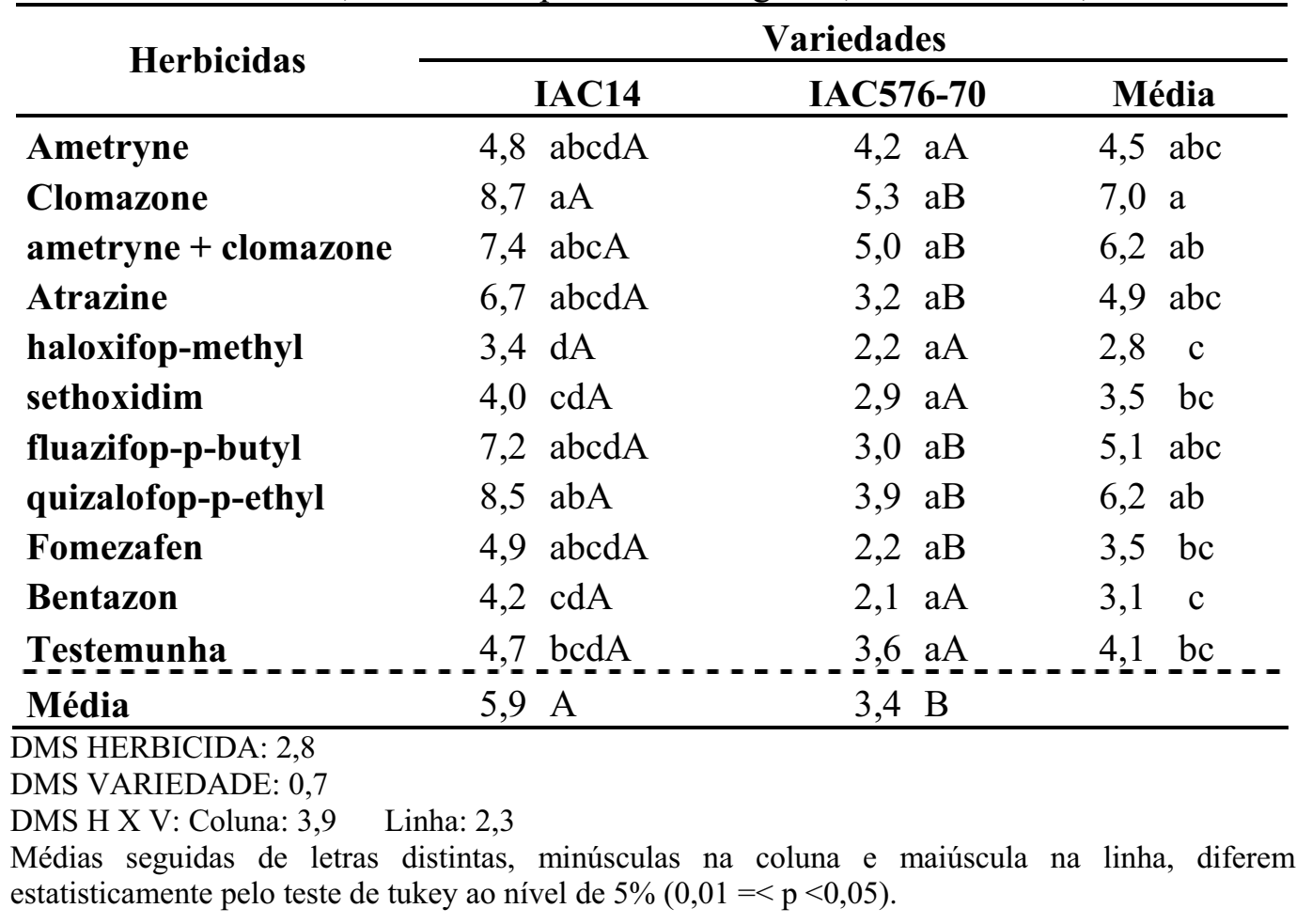

\subsubsection{Produtividade de matéria seca da parte aérea}

Para as interações dos fatores herbicidas e variedades na Fazenda

Experimental São Manuel a produtividade de massa seca da parte aérea das plantas não apresentou diferenças estatísticas significativas. Porém, os fatores variedade e herbicida apresentaram significância estatística. Na mesma maneira, na Fazenda Experimental Lageado, a interação herbicidas e variedades apresentou significância estatística, da mesma forma como ocorre para os fatores herbicidas e variedades isoladamente. Os efeitos dos herbicidas na produtividade de matéria seca, na Fazenda Experimental São Manuel e Lageado estão representados na Tabelas 22 e 23, respectivamente.

$\mathrm{Na}$ Tabela 22, nota-se que não ocorrem diferenças significativas do efeito do herbicida na variedade IAC576-70, o mesmo não ocorre na variedade IAC14. Observa-se que a mistura ametryne + clomazone proporcionou maior produtividade de massa seca da parte aérea e as moléculas clomazone e bentazon as menores produtividades de materia seca da parte aérea. Ainda assim, a variedade IAC14 obteve maior produtividade. As moléculas ametryne + clomazone independente da variedade foi a que mais produziu massa seca da parte aérea e as moléculas haloxifop-methyl, sethoxidim, bentazon e a testemunha foram as que obtiveram menor 
produtividade de matéria seca da parte aérea, esse fato é explicado pelo menor número de plantas na testemunha decorrente das capinas.

Tabela 22. Produtividade de matéria seca da parte aérea $\left(\mathrm{t} \mathrm{ha}^{-1}\right)$ das variedades IAC14 e IAC576-70, Fazenda Experimental São Manuel, São Manuel SP, 2009.

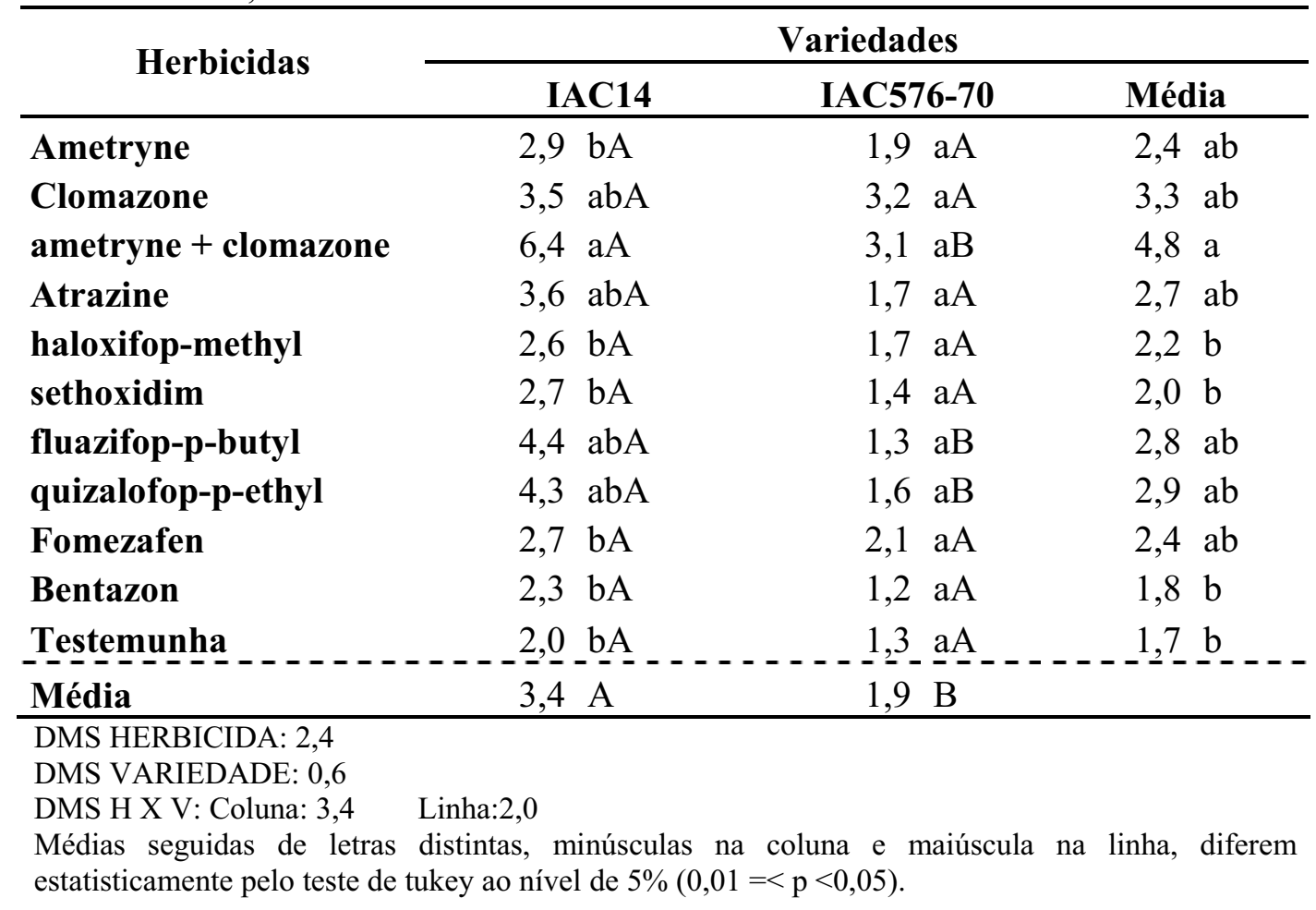

$\mathrm{Na}$ Tabela, 23, registra-se que houve diferenças na resposta as moléculas dos herbicidas aplicados na variedade IAC14, com haloxifop-methyl e sethoxidim influenciando em menor produtividade de massa seca da parte aérea e o herbicida quizalofop-p-ethyl em maior produtividade. Na variedade IAC576-70 não houve efeito dos herbicidas na produtividade de matéria seca da parte aérea das plantas. No entanto, a variedade IAC14 obteve maior produção de massa seca. Observa-se na mesma Tabela que, independente da variedade, a molécula clomazone proporcionou boa produção massa seca das plantas e a molécula haloxifop-methyl menor. 
Tabela 23. Produtividade de matéria seca da parte aérea $\left(\mathrm{t} \mathrm{ha}^{-1}\right)$ das variedades IAC14 e IAC576-70, Fazenda Experimental Lageado, Botucatu - SP, 2009.

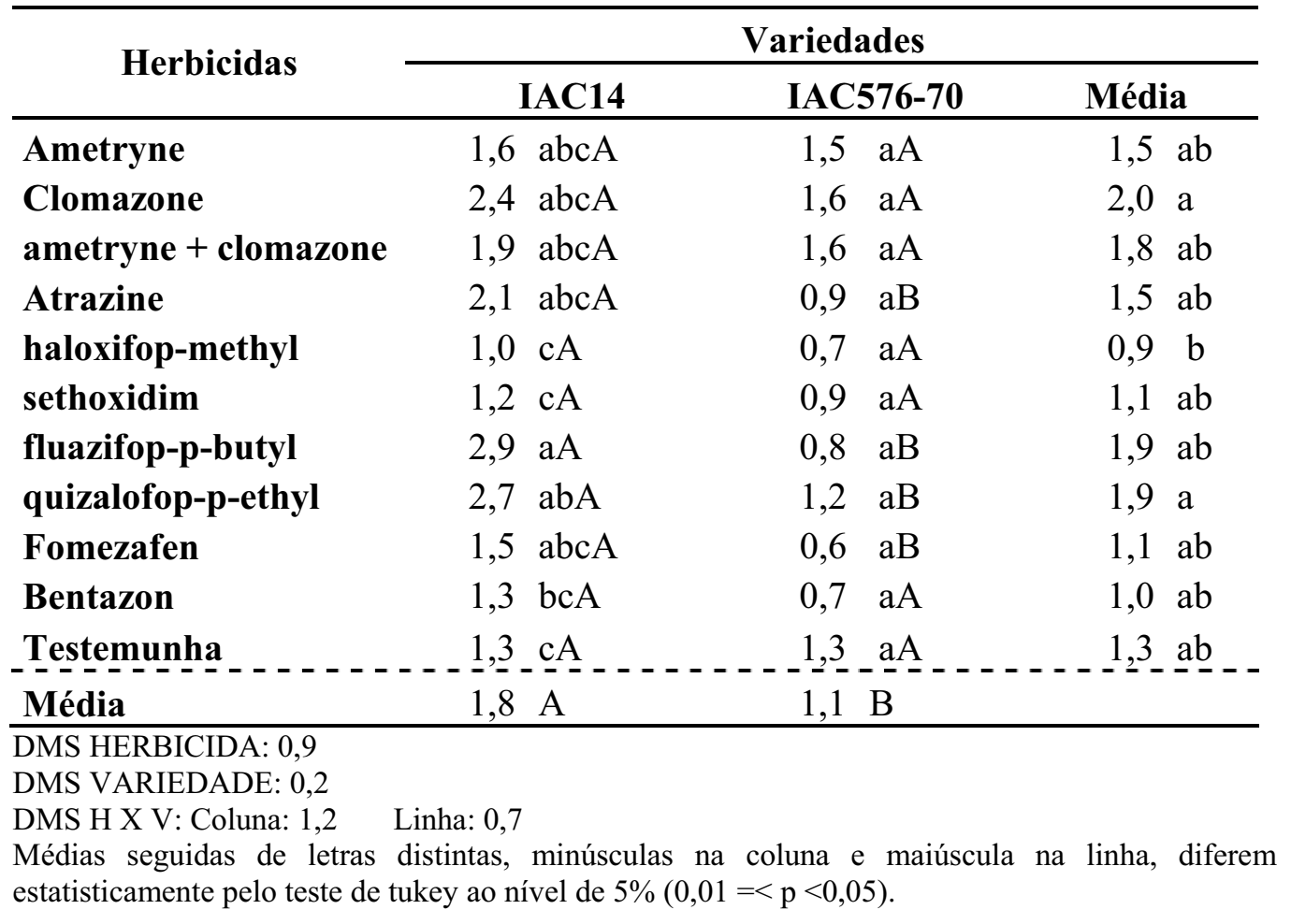

\subsubsection{Porcentagem de matéria seca da parte aérea}

As interações dos fatores herbicidas e variedades na Fazenda Experimental São Manuel e Lageado não influíram significativamente na porcentagem de matéria seca, tão pouco, os fatores variedades e herbicidas.

\subsection{Características da parte subterrânea da planta}

Os resultados da análise de variância feita para as características da parte subterrânea da planta nas Fazendas Experimentais São Manuel e Lageado encontram-se resumidos nas Tabelas 24 e 25, respectivamente, onde são apresentados os valores de F para as causas de variação e sua interação, e o desdobramento dos graus de liberdade. Nas Tabelas 24 e 25 , encontrase a produtividade de cepa em $\mathrm{t} \mathrm{ha}^{-1}$ ( $\mathrm{t}$ cepa), produtividade de matéria seca cepa em $\mathrm{t} \mathrm{ha}^{-1}$ ( $\mathrm{t}$ MS cepa), porcentagem de matéria seca cepa (\% MS cepa) diâmetro da raiz em $\mathrm{cm}$ (DR), comprimento da raiz em $\mathrm{cm}(\mathrm{CR})$, produtividade de raiz em $\mathrm{t} \mathrm{ha}^{-1}$ ( $\mathrm{t}$ raiz), produtividade de matéria seca da raiz em $\mathrm{t} \mathrm{ha}^{-1}$ ( $\mathrm{t}$ MS raiz), porcentagem matéria seca raiz (\% MS RAIZ) e porcentagem do índice de colheita (IC). 
Tabela 24. Resumo da análise de variância com valores de F calculados para as causas de variação e sua interação e médias para a produtividade de cepa em $\mathrm{t} \mathrm{ha}^{-1}$ ( $\mathrm{t}$ cepa), produtividade de matéria seca cepa em tha ${ }^{-1}$ ( $\mathrm{MS}$ cepa), porcentagem de matéria seca cepa (\% MS cepa) diâmetro da raiz em $\mathrm{cm}$ (DR), comprimento da raiz em $\mathrm{cm}(\mathrm{CR})$, produtividade de raiz $\mathrm{em} \mathrm{tha}^{-1}$ ( $\mathrm{t}$ raiz), produtividade de matéria seca da raiz em $\mathrm{t} \mathrm{ha}^{-1}$ ( $\mathrm{t} \mathrm{MS} \mathrm{raiz),} \mathrm{porcentagem} \mathrm{matéria} \mathrm{seca} \mathrm{raiz} \mathrm{( \%}$ MS RAIZ) e porcentagem do índice de colheita (IC) na Fazenda Experimental São Manuel, São Manuel - SP, 2009.

\begin{tabular}{|c|c|c|c|c|c|c|c|c|c|}
\hline $\begin{array}{c}\text { Causas da } \\
\text { variação }\end{array}$ & t cepa & $\begin{array}{l}\mathrm{MS} \\
\text { cepa }\end{array}$ & $\begin{array}{l}\% \mathrm{MS} \\
\text { сера }\end{array}$ & DR & CR & t raiz & $\begin{array}{l}\text { MS } \\
\text { raiz }\end{array}$ & $\begin{array}{l}\text { MS } \\
\text { raiz }\end{array}$ & IC \\
\hline BLOCO & $5,49 * *$ & $4,80 * *$ & $3,75^{* *}$ & $0,68 \mathrm{~ns}$ & $4,55^{* *}$ & $7,19 * *$ & $4,48 * *$ & $6,50 * *$ & $4,35 * *$ \\
\hline HERBICIDA (H) & $2,12 * *$ & $2,62 * *$ & $1,82 \mathrm{~ns}$ & $1,71 \mathrm{~ns}$ & $1,22 \mathrm{~ns}$ & $1,42 \mathrm{~ns}$ & $1,06 \mathrm{~ns}$ & $1,87 \mathrm{~ns}$ & $1,34 \mathrm{~ns}$ \\
\hline VARIEDADE (V) & $17,45^{* *}$ & $30,81 * *$ & $16,13 * *$ & $32,36 * *$ & $1,16 \mathrm{~ns}$ & $52,17 * *$ & $36,53 * *$ & $2,68 \mathrm{~ns}$ & $0,52 \mathrm{~ns}$ \\
\hline$\underline{V} \underset{-}{X} \mathbf{H}$ & $1.09 \mathrm{~ns}$. & $1,74 n s$ & $1,45 \underline{n s}$. & $1,27 \mathrm{~ns}$ & $1,82 \mathrm{~ns}$ & 1,49 ns & $0,91 \mathrm{~ns}$ & $\underline{0}, 65 \underline{n} \mathrm{n}$ & $\underline{0}, \underline{90 \mathrm{~ns}}$ \\
\hline Média & 4,60 & 1,81 & 39,17 & 4,30 & 39,02 & 21,67 & 9,06 & 41,87 & 64,77 \\
\hline C.V (\%) & 22,14 & 23,99 & 11,42 & 8,41 & 11,47 & 28,58 & 41,66 & 30,67 & 11,46 \\
\hline
\end{tabular}

NS: não signifivativo $(\mathrm{P}>0,05) * *: \mathrm{P}<0,05 ; \mathrm{P}<0,01$.

Tabela 25. Resumo da análise de variância com valores de F calculados para as causas de variação e sua interação e médias para para a produtividade de cepa em $\mathrm{t} \mathrm{ha}^{-1}$ ( $\mathrm{t}$ cepa), produtividade de matéria seca cepa em $\mathrm{t}$ $\mathrm{ha}^{-1}$ ( $\mathrm{t}$ MS cepa), porcentagem de matéria seca cepa (\% MS cepa) diâmetro da raiz em cm (DR), comprimento da raiz em $\mathrm{cm}(\mathrm{CR})$, produtividade de raiz $\mathrm{em} \mathrm{tha}^{-1}$ ( $\mathrm{t}$ raiz), produtividade de matéria seca da raiz em t ha ${ }^{-1}$ ( $\mathrm{MS}$ raiz), porcentagem matéria seca raiz (\% MS RAIZ) e porcentagem do índice de colheita (IC)Na Fazenda Experimental Lageado, Botucatu - SP, 2009.

\begin{tabular}{|c|c|c|c|c|c|c|c|c|c|}
\hline Causas da variação & t cepa & $\begin{array}{l}\mathrm{t} \mathrm{MS} \\
\text { cepa }\end{array}$ & MS cepa & DR & $\mathbf{C R}$ & $\begin{array}{l}\text { t raiz } \\
\text { ha }^{1} \\
\end{array}$ & $\begin{array}{l}\text { t MS } \\
\text { raiz }\end{array}$ & $\begin{array}{l}\text { MS } \\
\text { raiz }\end{array}$ & IC \\
\hline BLOCO & $5,11 * *$ & $1,79 \mathrm{~ns}$ & $0,56 \mathrm{~ns}$ & $0,91 \mathrm{~ns}$ & $2,60 \mathrm{~ns}$ & $9,95 * *$ & $5,44 * *$ & $2,01 \mathrm{~ns}$ & $2,01 \mathrm{~ns}$ \\
\hline HERBICIDA (H) & $2,11 *$ & $1,09 \mathrm{~ns}$ & $1,39 \mathrm{~ns}$ & $0,76 \mathrm{~ns}$ & $1,68 \mathrm{~ns}$ & $3,61 * *$ & $2,76^{* *}$ & $0,57 \mathrm{~ns}$ & $0,57 \mathrm{~ns}$ \\
\hline VARIEDADE (V) & $0,17 \mathrm{~ns}$ & $0,03 \mathrm{~ns}$ & $0,44 \mathrm{~ns}$ & $8,08 * *$ & $5,53 *$ & $20,03 * *$ & $13,01 * *$ & $1,47 \mathrm{~ns}$ & $1,47 \mathrm{~ns}$ \\
\hline V.X. & $1,33 \mathrm{~ns}$ & $2,66 * *$ & $1,20 \mathrm{~ns}$ & $0,96 \mathrm{~ns}$ & $1,62 \mathrm{~ns}$ & $0,72 \mathrm{~ns}$. & $0,99 \mathrm{~ns}$. & $0,99 \mathrm{~ns}$ & $0,99 \mathrm{~ns}$ \\
\hline Média & 3,44 & 1,36 & 40,08 & 4,49 & 32,76 & 12,16 & 5,38 & 42,99 & 42,99 \\
\hline C.V (\%) & 28,45 & 38,98 & 32,21 & 32,26 & 11,98 & 33,56 & 47,36 & 18,22 & 18,22 \\
\hline
\end{tabular}

NS: não signifivativo $(\mathrm{P}>0,05) * *: \mathrm{P}<0,05$;

\subsubsection{Produtividade de cepas}

As interações dos fatores herbicidas e variedades na Fazenda Experimental São Manuel não influíram significativamente na produtividade de cepas. No entanto, os fatores variedades e herbicidas apresentam significância estatística. $\mathrm{Na}$ mesma forma na Fazenda Experimental Lageado as interações dos fatores herbicidas e variedades não influíram 
significativamente na produtividade de cepas, assim como o fator variedade. No entanto, o fator herbicida apresenta significância. Os efeitos dos herbicidas na produção de cepas em ambas as variedades, na Fazenda Experimental São Manuel e Lageado estão representados na Tabelas 26 e 27.

Observa-se na Tabela 26, que não há diferenças estatísticas nos efeitos dos herbicidas na variedade IAC14. O mesmo não acontece na variedade IAC576-70, pois houve maior produção de cepa quando aplicada a molécula clomazone e menor quizalofop-p-ethyl, sendo que o restante dos tratamentos não deferiram entre si. Entretanto a variedade IAC14, obteve maior produtividade média de cepas por hectare. Quando observado o efeito das moléculas observa-se, que independente da variedade, as mesmas não causam danos a produtividade média de cepas por hectare entre herbicidas.

Tabela 26. Produtividade de cepa $\left(\mathrm{t} \mathrm{ha}^{-1}\right)$ das variedades IAC14 e IAC576-70. Fazenda Experimental São Manuel, São Manuel - SP, 2009.

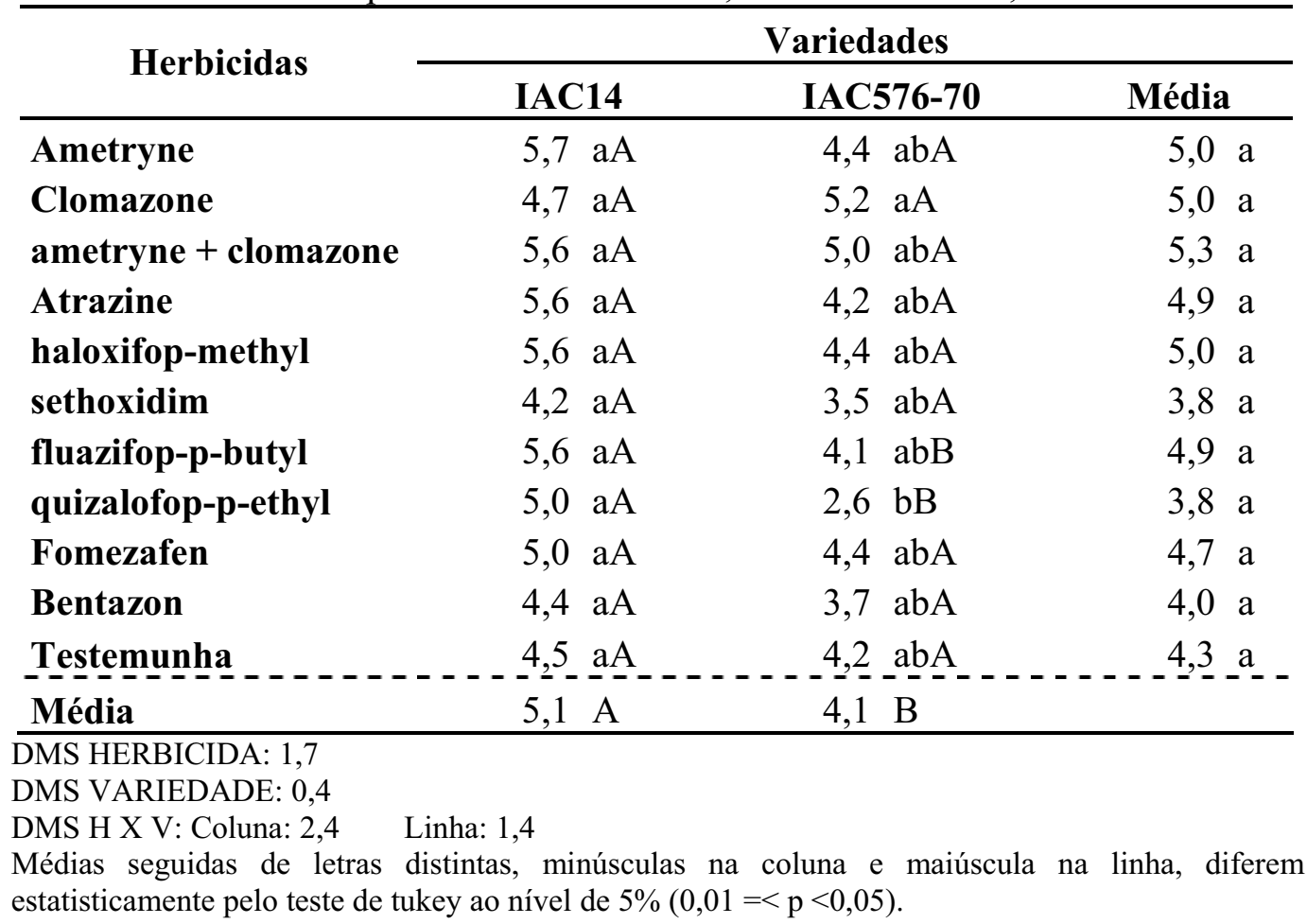

$\mathrm{Na}$ Tabela 27, nota-se que não houve efeito dos herbicidas nas variedades IAC14 e IAC576-70, nem na produção média de cepas das mesmas. O tratamento com menor produtividade de matéria verde das cepas foi bentazon quando aplicado na variedade IAC576-70 e a maior produtividade com a molécula clomazone aplicado na variedade IAC14. Somente a molécula 
ametryne se comporta de forma diferente quando comparadas as médias entre variedades, demonstrando que a molécula se mostra mais seletiva a variedade IAC576-70.

A molécula clomazone aplicada em pré-emergência da cultura inpendente da variedade obteve maior produtividade de cepas por hectare, o mesmo não ocorreu com as moléculas quizalofop-p-ethyl e fomezafen que apresentaram a menor produtividade de cepas por hectare.

Tabela 27. Produtividade de cepa $\left(\mathrm{t} \mathrm{ha}^{-1}\right)$ das variedades IAC14 e IAC576-70. Fazenda Experimental Lageado, Botucatu - SP, 2009.

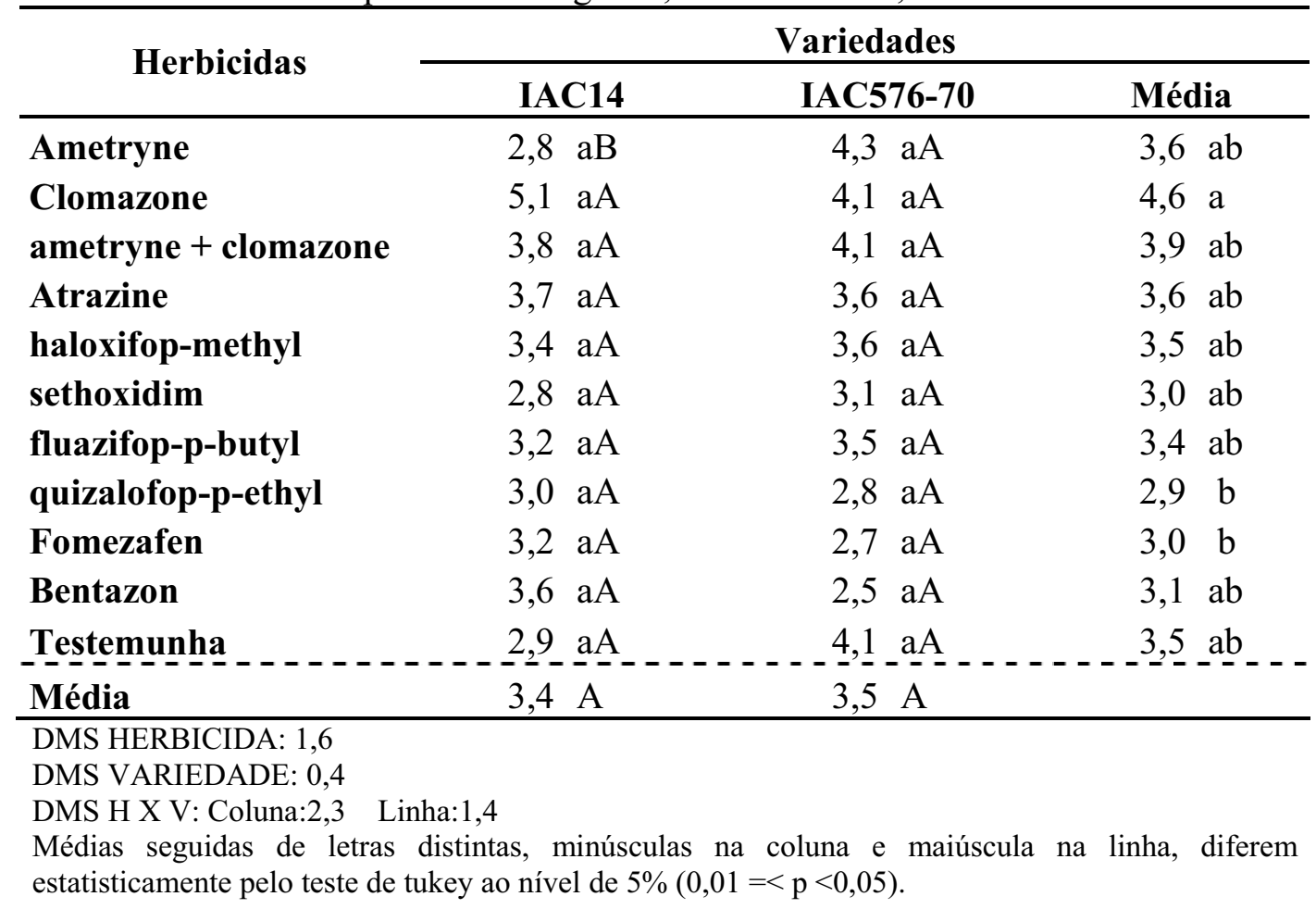

\subsubsection{Produtividade de matéria seca das cepas}

As interações dos fatores herbicidas e variedades na Fazenda Experimental São Manuel não influíram significativamente na produtividade de matéria seca das cepas, tão pouco o fator herbicidas. No entanto, o fator herbicida apresentou significância estatística. Na Fazenda Experimental Lageado, os fatores analisados não influíram significativamente a produtividade de matéria seca das cepas. Os efeitos dos herbicidas na produtividade de cepas em ambas as variedades, na Fazenda Experimental São Manuel estão representados na Tabela 28.

Verifica-se que não houve influência dos herbicidas na produtividade de matéria seca das cepas das plantas da variedade IAC14. Porém o mesmo não acontece na variedade 
IAC576-70, a qual apresentou maior produtividade de matéria seca quando da aplicação da molécula clomazone aplicada em pré-emergência e menor da molécula quizalofop-p-ethyl aplicada em pós-emergência da cultura. No entanto, a variedade IAC14, em média obteve maior produtividade de matéria seca das cepas das plantas. A molécula ametryne, atrazine fluazifop-Pbutil e quizalofop-p-ethyl apresentam diferenças estatísticas significativas quando observado seu efeito nas variedades separadamente, obtém maiores produtividades quando tratadas as plantas da variedade IAC14. As moléculas de herbicidas independente das variedades não influem na produtividade de matéria seca das plantas por hectare.

Tabela 28. Produtividade de matéria seca das cepas $\left(\mathrm{t} \mathrm{ha}^{-1}\right)$ das variedades IAC14 e IAC576-70. Fazenda Experimental São Manuel, São Manuel - SP, 2009.

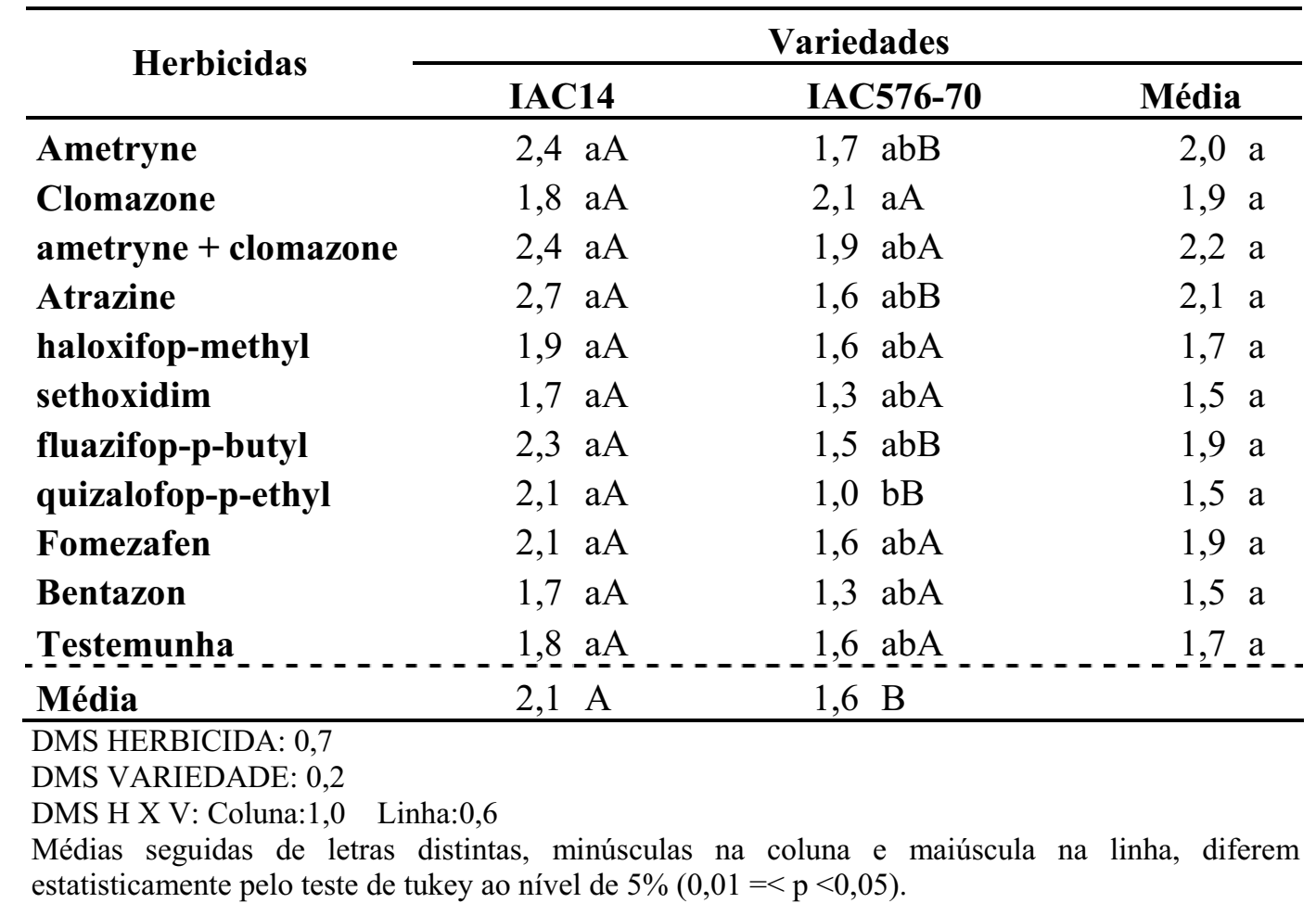

\subsubsection{Porcentagem de matéria seca das cepas}

As interações dos fatores herbicidas e variedades na Fazenda Experimental São Manuel e Lageado não apresentaram diferenças significativas na porcentagem de massa seca, tão pouco, os fatores variedades e herbicidas. 


\subsubsection{Porcentagem de raízes comercias}

$\mathrm{Na}$ figura 6, verifica-se o percentual de raízes comercias na Fazenda Experimental São Manuel, observa-se que independente da variedade quando aplicado ametryne o percentual é igual. No entanto, o mesmo não acontece com o restante dos tratamentos.

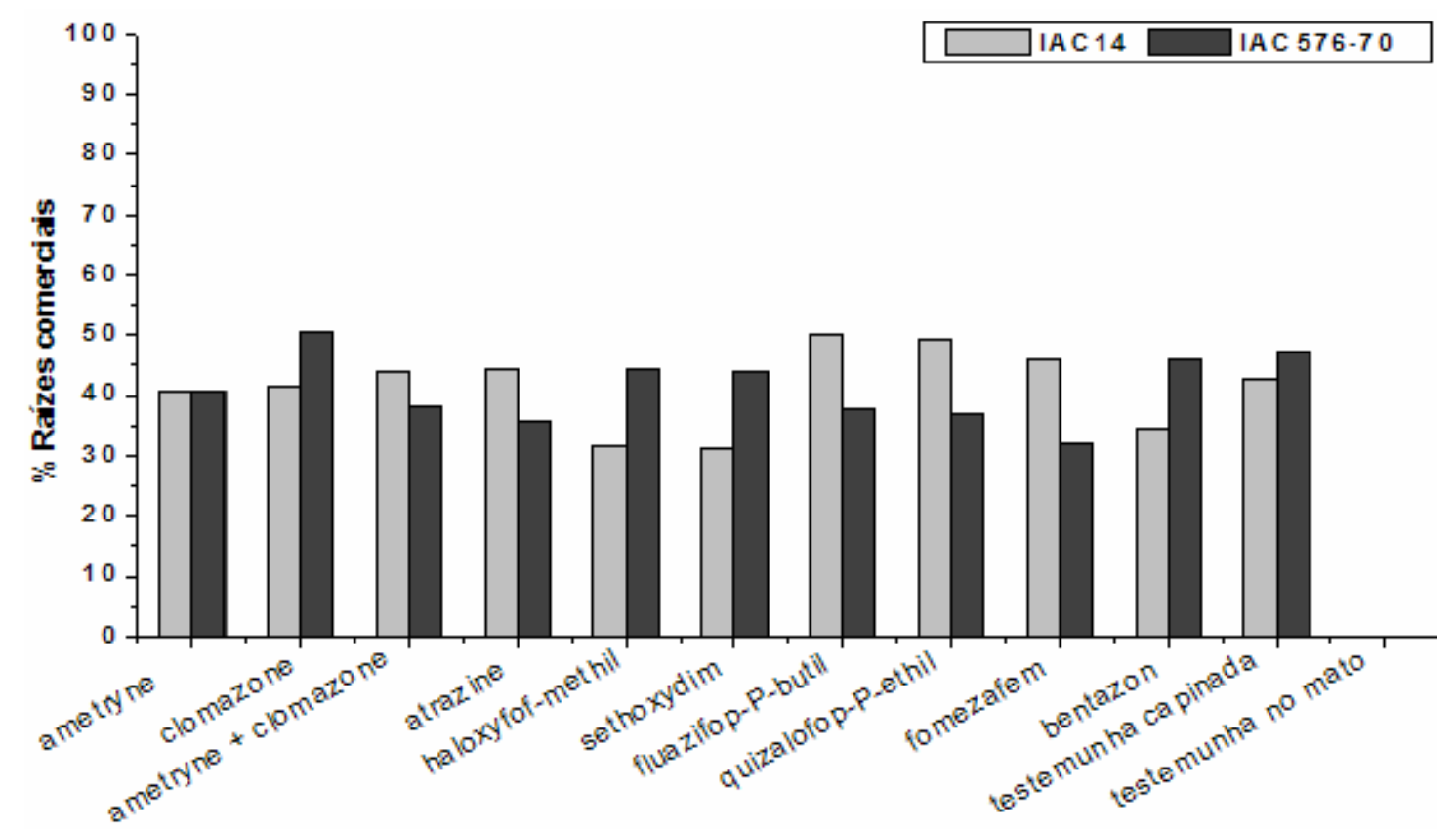

Figura 6. Porcentagem de raízes comerciais e descartáveis por hectare das variedades IAC14 e IAC7560-70, em função das moléculas de herbicidas aplicadas em pré e pósemergência na Fazenda Experimental São Manuel em São Manuel-SP.

A porcentagens de raízes comerciais na Fazenda Experimental São Manuel, Figura 6, foi maior nos tratamentos que houve a aplicação das moléculas fluazifop-P-butil e quizalofop-P-ethyl aplicados na variedade IAC14 e clomazone na variedade IAC576-70. O resultado é interessante, pois a variedade IAC576-70 tem sua demanda para consumo in natura e seu aspecto é importante para venda. As menores porcentagens de raízes comercias foram observadas quando houve a aplicação das moléculas haloxyfof-methil, sethoxidim e bentazon na variedade IAC14 e fomezafen na variedade IAC576-70.

$\mathrm{Na}$ figura 7, verifica-se o percentual de raízes comercias na Fazenda Experimental Lageado, observa-se que o maior percentual de raízes comerciais foi obtido com a aplicação das moléculas clomazone, fluazifop-P-butil e a testemunha capinada na variedade IAC14, as menores porcentagens foram na variedade IAC576-70, diante da aplicação das moléculas 
atrazine, haloxyfof-methil, sethoxidim. Nos tratamentos que receberam a molécula bentazon, independente da variedade, as porcentagens de raízes comercias foram baixas.

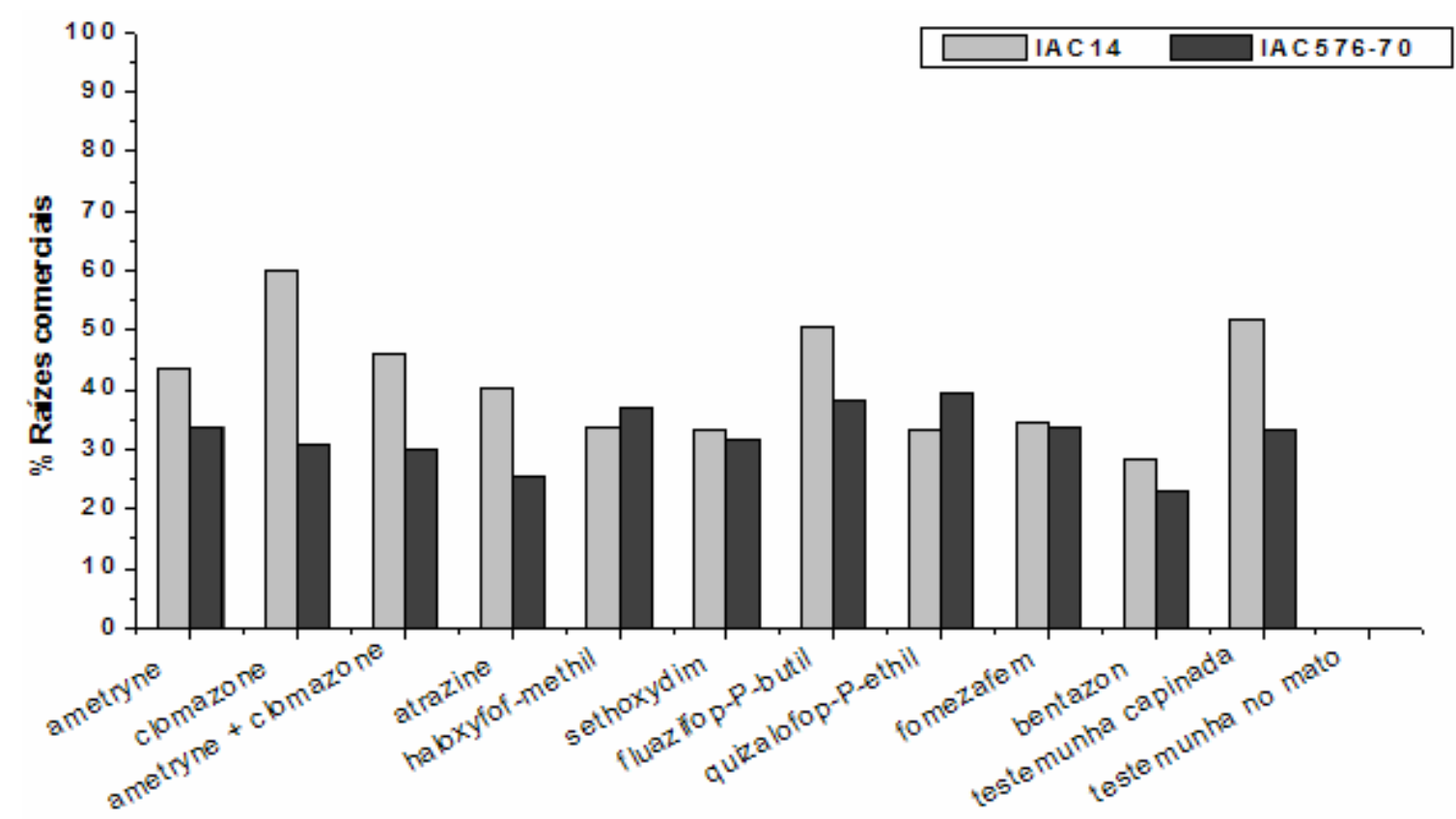

Figura 7. Porcentagem de raízes comerciais e descartáveis por hectare das variedades IAC14 e IAC7560-70, em função das moléculas de herbicidas aplicadas em pré e pósemergência na Fazenda Experimental Lageado em Botucatu-SP.

\subsubsection{Diâmetro das raízes}

As interações dos fatores herbicidas e variedades na Fazenda Experimental São Manuel e Lageado não influíram significativamente no diâmetro das raízes, tão pouco o fator herbicida. No entanto, o fator variedade apresenta significância. Os efeitos dos herbicidas na produtividade de cepas em ambas as variedades, na Fazenda Experimental São Manuel e Lageado estão representados na Tabelas 29 e 30, respectivamente.

Na Tabela 29, encontram-se as médias de diâmetro das raízes de mandioca na Fazenda Experimental São Manuel, nota-se que quando aplicada a molécula ametryne e fluazifop-P-butil na variedade IAC14, encontra-se maiores diâmetros diferindo da aplicação da testemunha na qual observa-se menor diâmetro. As moléculas não proporcionaram diferenças estatísticas na variedade IAC576-70, no entanto a variedade IAC14 proporcionou maior diâmetro que a variedade IAC576-70. Os efeitos das moléculas diferiram entre as variedades, ametryne, 
fluazifop-p-butyl, fluazifop-P-butil e quizalofop-p-ethyl, sendo que quando analisados os efeitos dos herbicidas independente da variedade observa-se que não há diferenças entre os tratamentos.

Tabela 29. Diâmetro das raízes $(\mathrm{cm})$ das variedades IAC14 e IAC576-70. Fazenda Experimental São Manuel, São Manuel - SP, 2009.

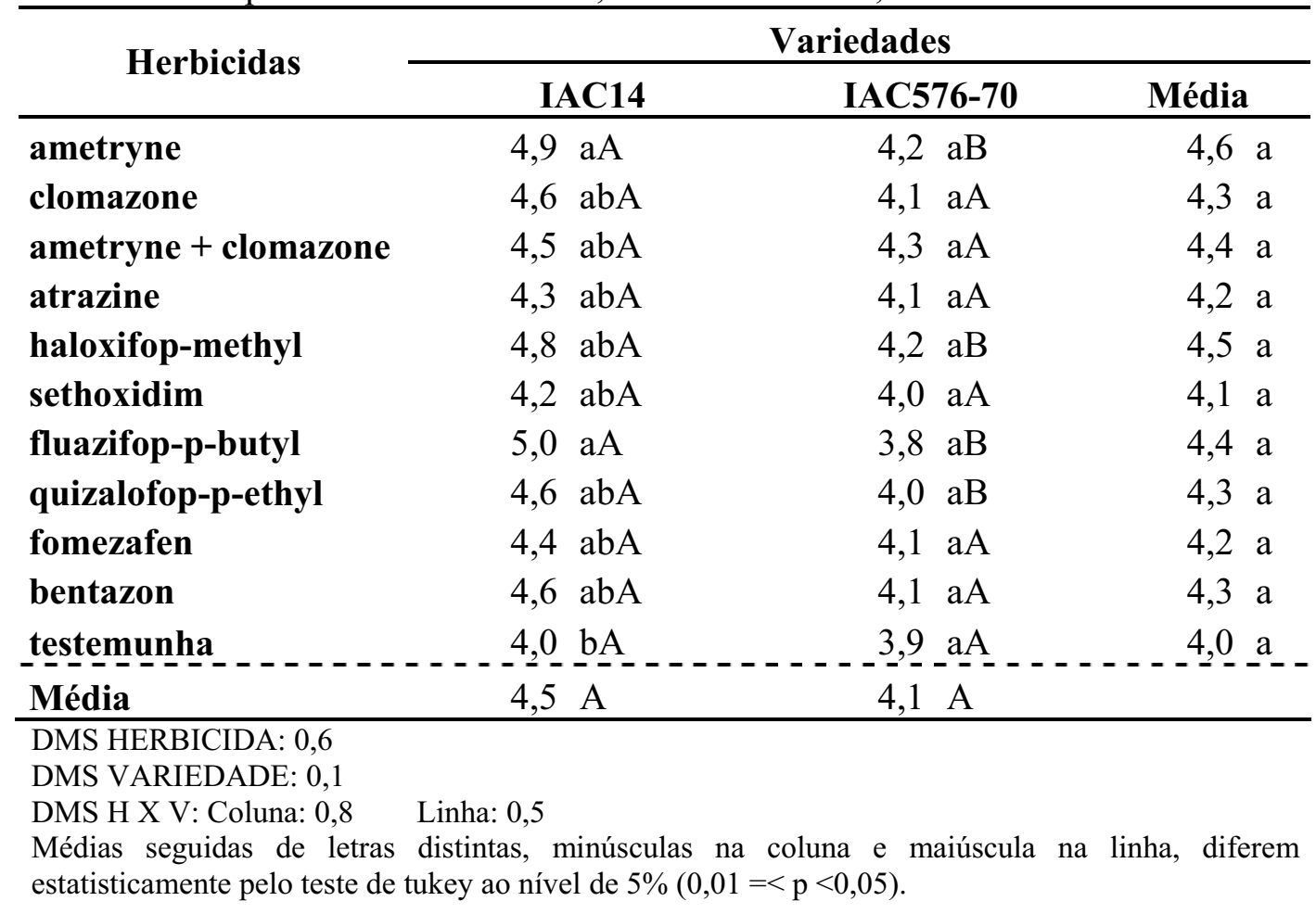

Na Tabela 30, encontram-se as médias dos diâmetros das raízes do ensaio da Fazenda Experimental Lageado. Observa-se que não ocorreram diferenças entre os herbicidas aplicados em ambas as variedades, sendo que o diâmetro da variedade IAC14 é maior do que a variedade IAC576-70. Somente para a molécula de herbicida fomezafen verifica-se diferença comparando-se as variedades. Independente da variedade não há influencia das moléculas aplicadas. Essa pequena variação encontrada no diâmetro entre os tratamentos é pouco pronunciada também em função dos dados de diâmetro médio obtidos a partir das raízes classificadas como comerciais.

Desta forma, diâmetro maior de raízes obtém uma melhor classificação, segundo os padrões adotados pelo (CEAGESP, 2008). Em trabalho realizado por Williams (1974), são demonstradas relações lineares entre a massa média e o diâmetro de raízes, de forma que quanto maior o diâmetro das raízes, maiores os rendimentos médios de raízes por planta. Tratando-se de raízes comerciais de mandioca de mesa, são desejáveis os maiores diâmetros de raízes. 
Tabela 30. Diâmetro das raízes (cm) das variedades IAC14 e IAC576-70. Fazenda Experimental Lageado, Botucatu - SP, 2009.

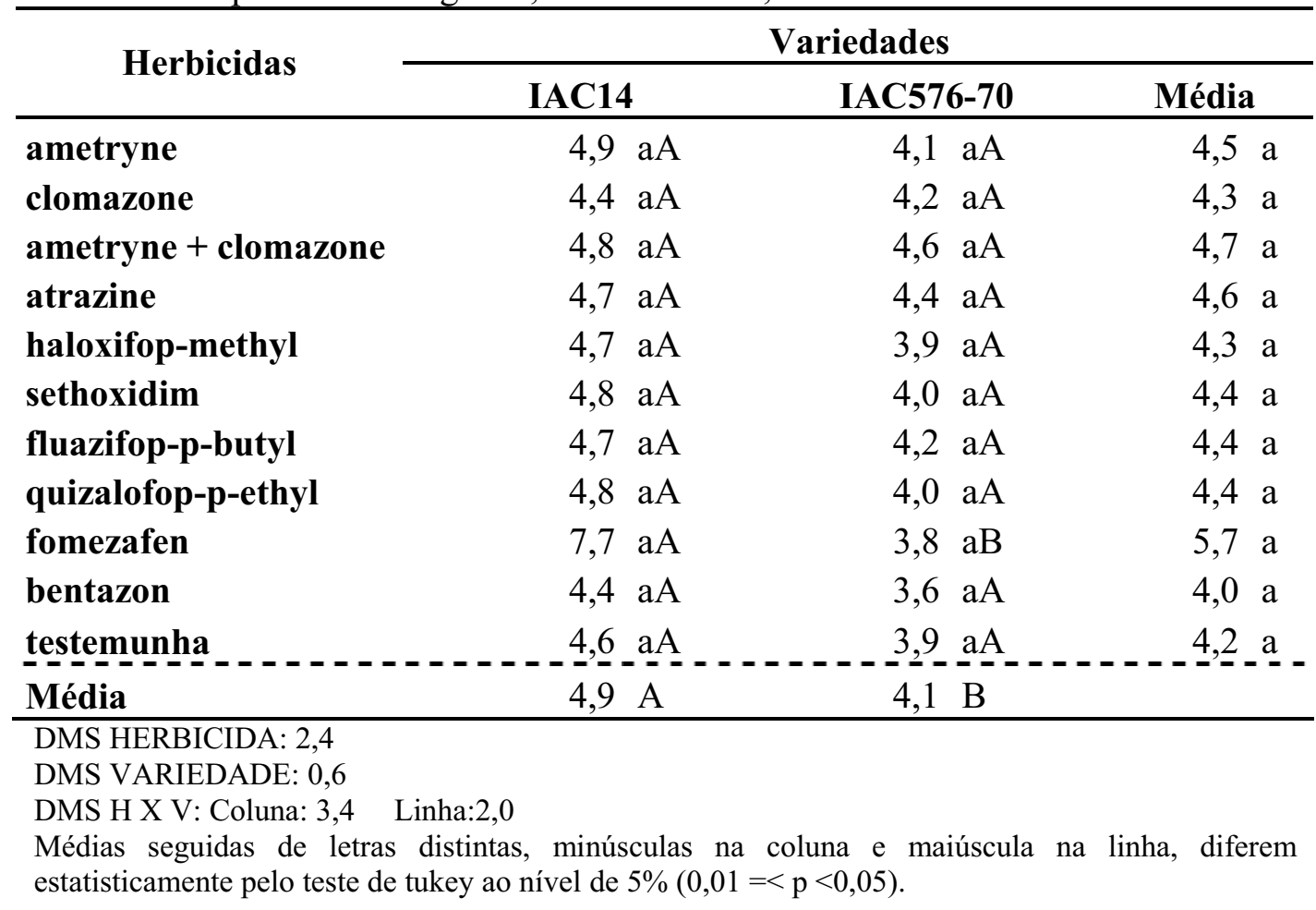

\subsubsection{Comprimento das raízes}

As interações dos fatores herbicidas e variedades na Fazenda Experimental São Manuel não influíram significativamente no comprimento das raízes no ponto de vista estatístico. Na Fazenda Experimental Lageado, as interações dos fatores herbicidas e variedades não influíram significativamente o comprimento das raízes, $\mathrm{m}$ mesmo correu com o fator herbicida. Entretanto, o fator variedade apresenta significância. Os efeitos dos herbicidas no comprimento das raízes em ambas as variedades, na Fazenda Experimental Lageado está representado na Tabela 31.

Desta forma, verificam-se os efeitos da aplicação das moléculas dos herbicidas sobre comprimento final das raízes das variedades de mandioca, no momento da colheita na Fazenda Experimental Lageado, registra-se que não há diferenças em função do herbicida aplicado na variedade IAC14. O mesmo não ocorre na variedade IAC576-70, quando aplicado as moléculas ametryne e fomezafen encontram-se maiores comprimentos e na aplicação da molécula bentazon menores comprimentos das raízes. Ocorre uma variação no comprimento das raízes em função da aplicação das moléculas de herbicidas de $25,8 \mathrm{~cm}$ a $36,6 \mathrm{~cm}$ na variedade IAC576-70 o que corresponde a um acréscimo de $10,8 \mathrm{~cm}$ ou $29,51 \%$. Observa-se que essa variedade tem maior 
comprimento das raízes. No entanto independente da variedade na qual os herbicidas são aplicados não ocorrem diferenças significativas entre elas.

A variação no comprimento de raízes comerciais de mandioca de mesa não é o fator determinante, devido IAC576-70 ser destinada a consumo in natura, o fator mais importante na classificação destas, é o diâmetro das raízes.

Tabela 31. Comprimento das raízes $(\mathrm{cm})$ das variedades IAC14 e IAC576-70. Fazenda Experimental Lageado, Botucatu - SP, 2009.

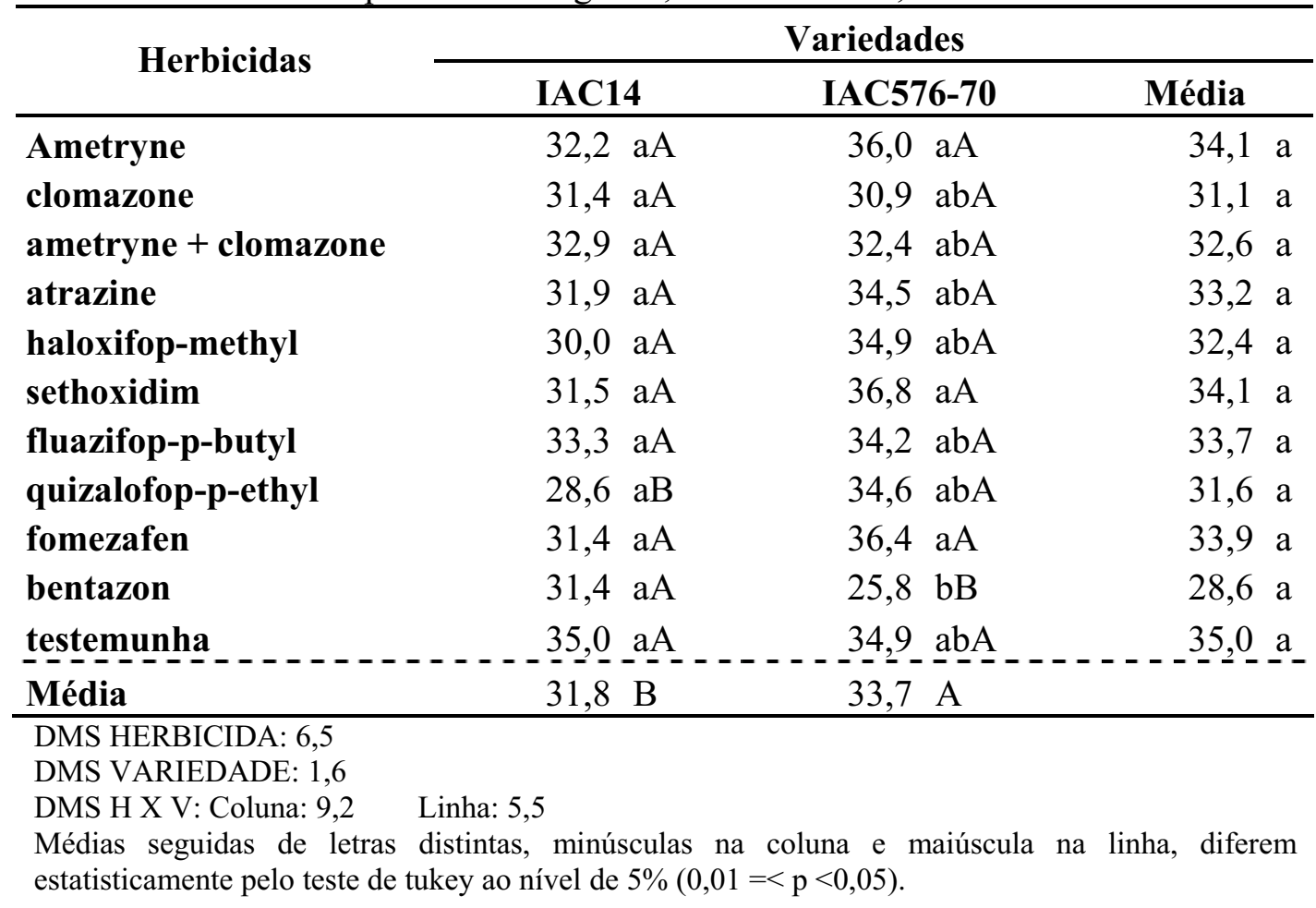

\subsubsection{Produtividade das raízes}

As interações dos fatores herbicidas e variedades na Fazenda Experimental São Manuel não influenciaram significativamente na produtividade das raízes de mandioca, tão pouco o fator herbicida. No entanto, o fator variedade apresentou significância. Na Fazenda Experimental Lageado, as interações dos fatores herbicidas e variedades não influenciaram significativamente na produtividade das raízes de mandioca. Porém, quando avaliados separadamente apresentaramm significância. Os efeitos dos herbicidas na produtividade das raízes em ambas as variedades, na Fazenda Experimental São Manuel e Lageado são apresentados na Tabelas 32 e 33, respectivamente. 
Tabela 32. Produtividade das raízes em $\mathrm{t} \mathrm{ha}^{-1}$ das raízes das variedades IAC14 e IAC576-70. Fazenda Experimental São Manuel, São Manuel - SP, 2009.

\begin{tabular}{|c|c|c|c|}
\hline \multirow{2}{*}{ Herbicidas } & \multicolumn{3}{|c|}{ Variedades } \\
\hline & IAC14 & IAC576-70 & Média \\
\hline ametryne & 30,3 aA & 21,6 aA & 25,9 a \\
\hline clomazone & $26,4 \mathrm{aA}$ & 19,4 aA & $22,9 \mathrm{a}$ \\
\hline ametryne + clomazone & 34,5 aA & $17,5 \mathrm{aB}$ & 26,0 a \\
\hline atrazine & $26,8 \mathrm{aA}$ & 19,5 aA & 23,1 a \\
\hline haloxifop-methyl & 24,3 aA & 16,0 aA & $20,2 \mathrm{a}$ \\
\hline sethoxidim & $21,9 \mathrm{aA}$ & $16,5 \mathrm{aA}$ & $19,2 \mathrm{a}$ \\
\hline fluazifop-p-butyl & 33,4 aA & $11,5 \mathrm{aB}$ & 22,4 a \\
\hline quizalofop-p-ethyl & $25,5 \mathrm{aA}$ & $16,6 \mathrm{aB}$ & 21,1 a \\
\hline fomezafen & 23,7 aA & $14,0 \mathrm{aB}$ & 18,9 a \\
\hline bentazon & $23,0 \mathrm{aA}$ & 15,5 aA & 19,3 a \\
\hline testemunha & $21,2 \mathrm{aA}$ & $17,9 \mathrm{aA}$ & $19,5 \mathrm{a}$ \\
\hline Média & $26,4 \mathrm{~A}$ & $16,9 \mathrm{~B}$ & \\
\hline
\end{tabular}

DMS HERBICIDA: 10,3

DMS VARIEDADE: 2,6

DMS H X V: Coluna: 14,6 Linha: 8,7

Médias seguidas de letras distintas, minúsculas na coluna e maiúscula na linha, diferem estatisticamente pelo teste de tukey ao nível de $5 \%(0,01=<\mathrm{p}<0,05)$.

Verifica-se nas Tabelas 32 que não existem diferenças estatísticas significativas entre os tratamentos utilizados na Fazenda Experimental São Manuel para ambas as variedades testadas. Observa-se que não há efeito significativo dos herbicidas. No entanto, quando aplicado em pré-emergência a mistura ametryne + clomazone na variedade IAC14 e a molécula ametryne aplicada na variedade IAC576-70 possibilitou produtividade média mais elevada. As moléculas clomazone, fluazifop-p-butyl, quizalofop-p-ethyl e fomezafen obtiveram maior produtividade quando aplicados na variedade IAC14. Sendo assim, no geral, a média da produtividade da variedade IAC14 é maior do que a da variedade IAC576-70.

$\mathrm{Na}$ Tabela 33, observa-se que há diferenças entre as moléculas de herbicidas aplicadas, nas duas variedades na variedade IAC14, a molécula clomazone obteve maior produtividade das raízes e a molécula fomezafen a menor. Na variedade IAC576-70 a molécula ametryne obteve a maior produtividade e a molécula bentazon a menor produtividade. No geral, independente da molécula aplicada, à variedade IAC14 foi mais produtiva. Observa-se que independente da variedade na qual as moléculas fomezafen e bentazon foram aplicadas, elas causam maior dano a produtividade da cultura. 
Tabela 33. Produtividade das raízes em $\mathrm{t} \mathrm{ha}^{-1}$ das variedades IAC14 e IAC576-70. Fazenda Experimental Lageado, Botucatu - SP, 2009.

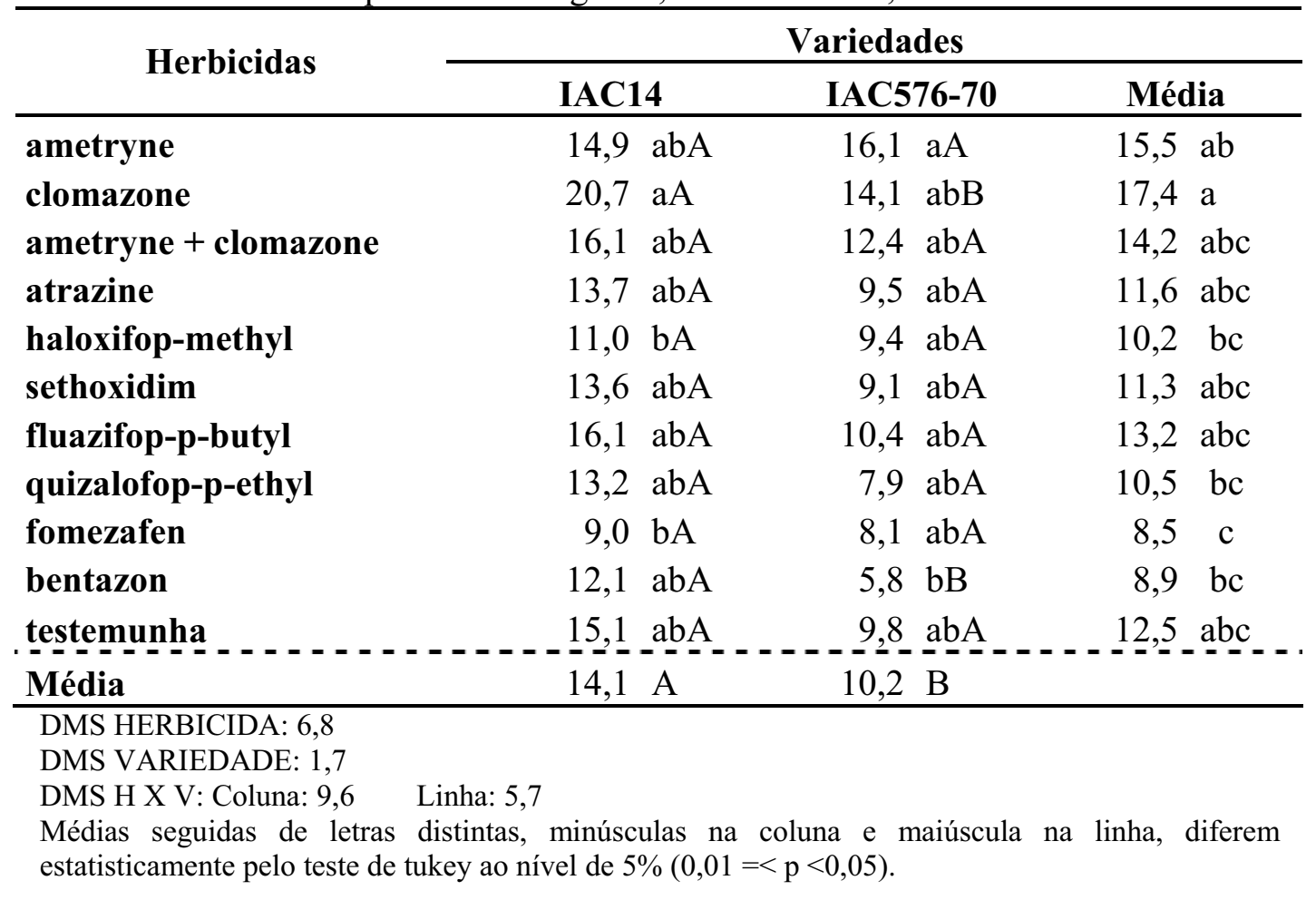

Verifica-se que há um incremento de aproximadamente $23 \mathrm{t} \mathrm{ha}^{-1}$ ou $66,53 \%$ na produtividade da menor para maior produtividade no ensaio feito em São Manuel, (Tabela 31), e de $16 \mathrm{t} \mathrm{ha}^{-1}$ ou aproximadamente 70\% no ensaio realizado na Fazenda Lageado, (Tabela 32).

As maiores produtividades foram alcançadas pela variedade IAC14, o que pode ser atribuída à característica varietal. Nota-se que os comprimentos e diâmetros são maiores na variedade IAC14, (Tabelas 29 a 31).

\subsubsection{Produtividade de matéria seca das raízes}

As interações dos fatores herbicidas e variedades na Fazenda Experimental São Manuel não influenciaram significativamente na produtividade de massa seca das raízes de mandioca, tão pouco o fator herbicida. No entanto, o fator variedade apresentou significância. Na Fazenda Experimental Lageado, as interações dos fatores herbicidas e variedades não influem significativamente na produtividade de matéria seca das raízes de mandioca. Entretanto quando avaliados separadamente apresentam diferenças estatísticas significativas. Os efeitos dos herbicidas na produtividade das raízes em ambas as variedades, na Fazenda Experimental São Manuel e Lageado são apresentados nas Tabelas 34 e 35, respectivamente. 
$\mathrm{Na}$ Tabela 34, observando a produtividade de matéria seca das raízes na Fazenda Experimental São Manuel, verifica-se que não ocorreram diferenças significativas entre os tratamentos aplicados na variedade IAC14, e o mesmo pode ser observado para a variedade IAC576-70. Verifica-se que a variedade IAC14 independente da molécula aplicada tem maior produtividade de matéria seca, quando comparada à variedade IAC576-70. Todavia, não seguem o mesmo padrão que a produtividade das raízes, fato relevante já que na compra das raízes a indústria leva em conta a matéria seca das mesmas. As variedades respondem de forma diferente a aplicação das moléculas clomazone, sethoxidim e fluazifop-p-butyl. Verifica-se que independente da molécula aplicada a média da produtividade não é afetada

Tabela 34. Produtividade de matéria seca das raízes $\left(\mathrm{t} \mathrm{ha}^{-1}\right)$ das variedades IAC14 e IAC576-70. Fazenda Experimental São Manuel, São Manuel - SP, 2009.

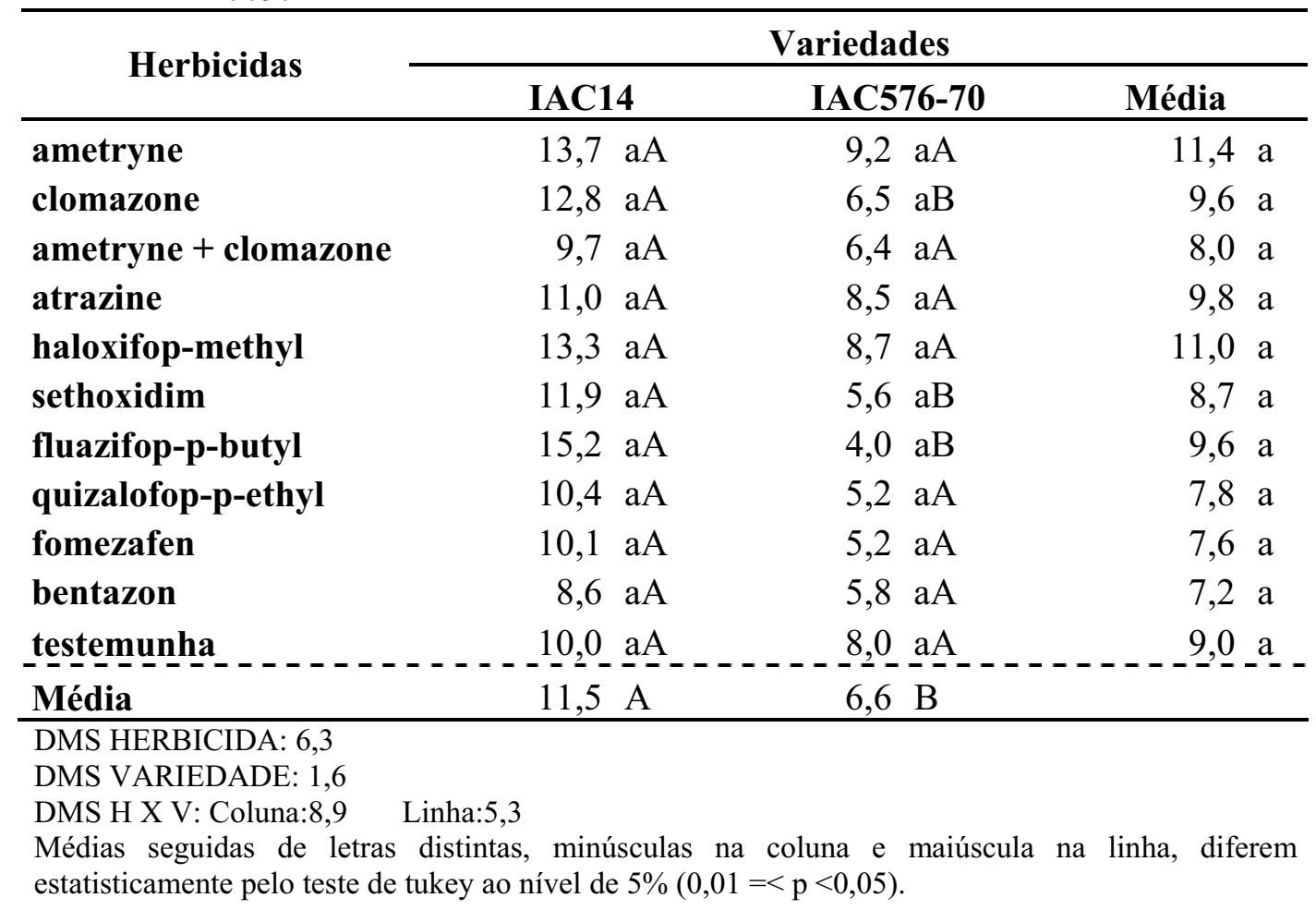

$\mathrm{Na}$ Tabela 35, analisando os dados de produtividade de matéria seca por hectare na Fazenda Experimental Lageado, verifica-se que houve diferença significativa entre as moléculas aplicadas na variedade IAC14. A molécula clomazone foi a que proporcionou maior produtividade de matéria seca das raízes e as moléculas haloxifop-methyl, fomezafen e bentazon foram as que proporcionaram menores produtividades de matéria seca das raízes. Quando observado o efeito das moléculas na variedade IAC576-70, não são verificados efeitos que proporcionassem diferenças significativas entre as moléculas. 
A variedade IAC14 em média foi mais produtiva do que a variedade IAC576-70. A molécula clomazone foi a única que proporcionou diferenças na produtividade de massa seca quando observado seu efeito nas variedades.

A molécula clomazone independente da variedade aplicada proporciona maior produtividade de matéria seca das raízes, diferente das moléculas haloxifop-methyl, fomezafen e bentazon que proporcionaram menores produtividades da massa seca das raízes.

Tabela 35. Produtividade de matéria seca das raízes $\left(\mathrm{t} \mathrm{ha}^{-1}\right)$ das variedades IAC14 e IAC576-70. Fazenda Experimental Lageado, Botucatu - SP, 2009.

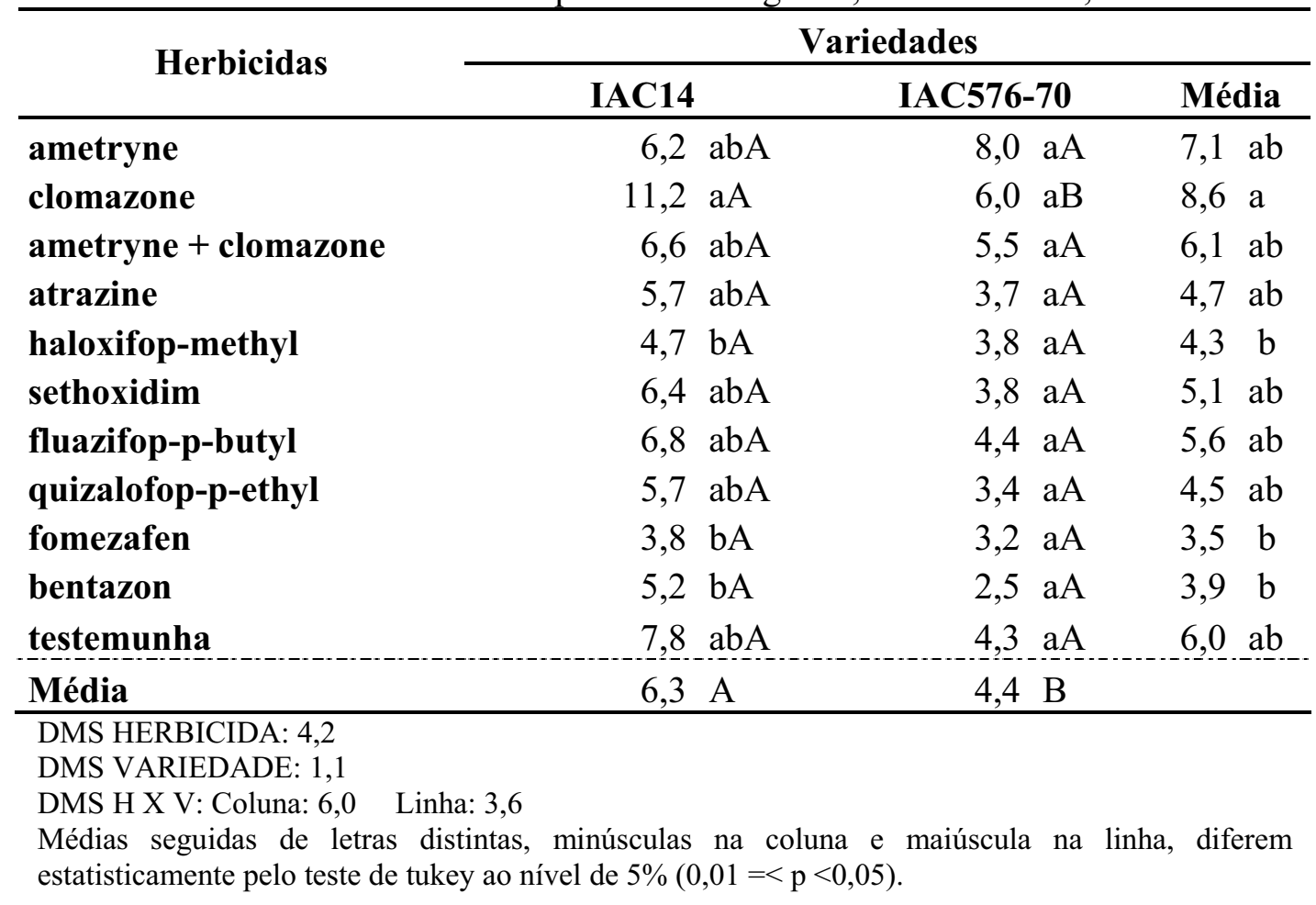

\subsubsection{Porcentagem de matéria seca das raízes}

As interações dos fatores herbicidas e variedades na Fazenda Experimental São Manuel e Lageado não influenciaram significativamente na porcentagem de matéria seca das raízes, tão pouco, os fatores variedades e herbicidas. Observa-se na Tabela 38, que na Fazenda Experimental São Manuel houve uma variação de 28,6\% na matéria seca das raízes, a molécula haloxifop-methyl obteve o maior percentual de massa seca e a mistura ametryne + clomazone a menor, ambas aplicadas na variedade IAC14. Na Tabela 39, observa-se na Fazenda Experimental Lageado ocorre uma variação menor que a ocorrida em São Manuel do percentual de materia seca das raízes com $14 \%$ de variação. A molécula clomazone aplicada na varieadade IAC14 
proporcionou maior percentual de matéria seca e a molécula atrazine menor percentual de matéria seca.

\subsubsection{0 Índice de colheita}

As interações dos fatores herbicidas e variedades na Fazenda Experimental São Manuel e Lageado não influíram significativamente no índice de colheita, tão pouco, os fatores variedades e herbicidas.

Tabela 36. Índice de colheita (\%) das variedades IAC14 e IAC576-70. Fazenda Experimental São Manuel, São Manuel - SP, 2009.

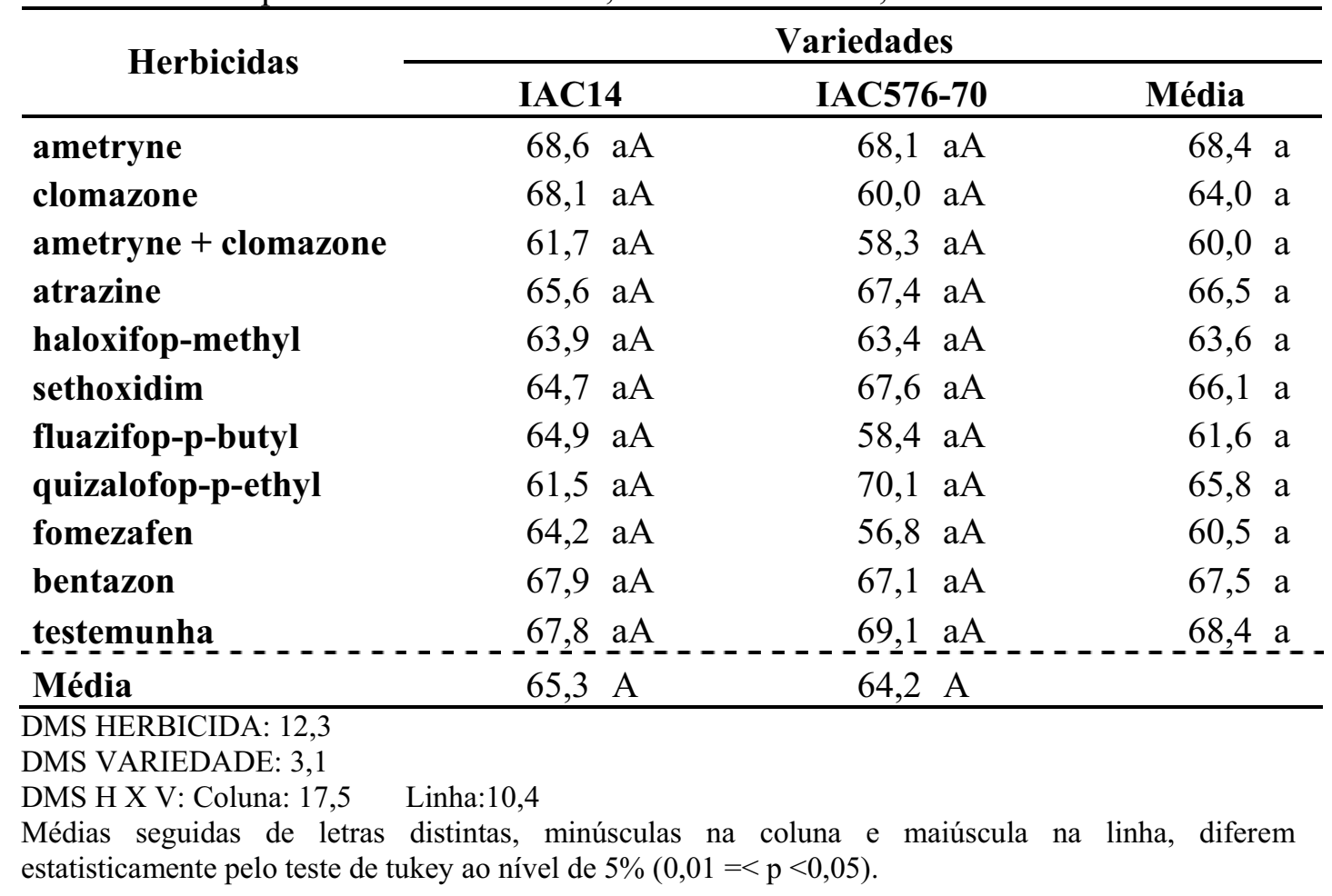

Os índices de colheita (ICs) apresentados na Tabela 36 e 37 demonstram uma variação de aproximadamente $20 \%$ entre o maior é menor índice nos dois ambientes. Observase que a variedade IAC14 apresenta no IC um percentual constante, apresentando característica de maior produção de parte aérea (Tabelas 22 e 23). De maneira geral, existem grandes variações nos ICs entre os diversos genótipos cultivados (kawano, 1982), de forma que elevados ICs são desejáveis, pois demonstram a capacidade das raízes atraírem e acumularem na forma de amido os carboidratos produzidos pela parte aérea (Enyi, 1973; Williams, 1972).

Aguiar, (2003) relata que a escolha da variedade a ser cultivada e a seleção de genótipos de mandioca com alto índice de colheita, além de relacionarem os maiores rendimentos 
comerciais, permitem uma elevada qualidade da produção das raízes demonstrada anteriormente pelos elevados diâmetros e massa média das raízes produzidas. Assim, podem fornecer aos agricultores maiores rendimentos econômicos em virtude da quantidade produzida e da qualidade da produção obtida.

No entanto, quando se trata de herbicidas, não se tem informação sobre esses parâmetros, sendo necessária uma quantidade maior de estudos para termos a segurança de que esses não sejam prejudiciais em outras condições de cultivo e a genótipos diferentes.

Tabela 37. Índice de colheita (\%) das variedades IAC14 e IAC576-70. Fazenda Experimental Lageado, Botucatu - SP, 2009.

\begin{tabular}{|c|c|c|c|c|c|c|}
\hline \multirow{3}{*}{$\begin{array}{l}\text { Herbicidas } \\
\text { ametryne }\end{array}$} & \multicolumn{6}{|c|}{ Variedades } \\
\hline & \multicolumn{2}{|c|}{ IAC14 } & \multicolumn{2}{|c|}{ IAC576-70 } & \multicolumn{2}{|c|}{ Média } \\
\hline & 39,82 & $\mathrm{aA}$ & 48,37 & $\mathrm{aA}$ & 44,1 & $\bar{a}$ \\
\hline clomazone & 51,92 & $\mathrm{aA}$ & 38,92 & $\mathrm{aB}$ & 45,4 & $\mathrm{a}$ \\
\hline ametryne + clomazone & 40,90 & $\mathrm{aA}$ & 44,12 & $\mathrm{aA}$ & 42,5 & $\mathrm{a}$ \\
\hline atrazine & 40,97 & $\mathrm{aA}$ & 38,25 & $\mathrm{aA}$ & 39,6 & $\mathrm{a}$ \\
\hline haloxifop-methyl & 43,87 & $\mathrm{aA}$ & 39,95 & $\mathrm{aA}$ & 41,9 & $\mathrm{a}$ \\
\hline sethoxidim & 46,45 & $\mathrm{aA}$ & 41,37 & $\mathrm{aA}$ & 43,9 & $\mathrm{a}$ \\
\hline fluazifop-p-butyl & 42,00 & $\mathrm{aA}$ & 41,67 & $\mathrm{aA}$ & 41,8 & $\mathrm{a}$ \\
\hline quizalofop-p-ethyl & 43,72 & $\mathrm{aA}$ & 42,87 & $\mathrm{aA}$ & 43,3 & $\mathrm{a}$ \\
\hline fomezafen & 41,72 & $\mathrm{aA}$ & 38,77 & $\mathrm{aA}$ & 40,2 & $\mathrm{a}$ \\
\hline bentazon & 42,87 & $\mathrm{aA}$ & 43,85 & $\mathrm{aA}$ & 43,3 & $\mathrm{a}$ \\
\hline testemunha & 49,85 & $\mathrm{aA}$ & 43,62 & $\mathrm{aA}$ & 46,7 & $\mathrm{a}$ \\
\hline Média & 44,0 & $\bar{A}$ & $1, \overline{9}$ & A & & \\
\hline $\begin{array}{l}\text { MS HERBICIDA: } 13,0 \\
\text { MS VARIEDADE: } 3,3 \\
\text { MS H X V: Coluna: } 18,4\end{array}$ & 1,0 & & & & & \\
\hline
\end{tabular}

\subsection{Balanço de massa e teor de amido}

Observa-se na Tabela 38 o balanço de massa e teor de amido na Fazenda Experimental São Manuel. Percebem-se que a aplicação dos herbicidas não influenciou o balanço de massa de ambas as cultivares. No entanto, quando aplicada à mistura de ametryne + clomazone em pré-emergência em ambas as variedades e a molécula fomezafen em pós-emergência na variedade IAC576-70, percebem-se melhores resultados, existe pequena diferença entre as variedades, diante da molécula de herbicida aplicada. 
Quando observado o teor de amido diante das moléculas, houve uma variação de 16,3 a 24,6\%, sendo que o tratamento com maior teor de amido foi na aplicação de bentazon na variedade IAC576-70 e o menor clomazone aplicado na variedade IAC576-70.

Tabela 38. Balanço de massa das raízes de mandioca nas variedades IAC14 e IAC576-70 no na Fazenda Experimental São Manuel em São Manuel-SP, 2009.

\begin{tabular}{|c|c|c|c|c|c|c|}
\hline TRATAMENTOS & $\begin{array}{l}\text { Modo de } \\
\text { aplicação }\end{array}$ & Casca & Ponta & $\begin{array}{c}\text { Polpa } \\
\% \\
\end{array}$ & MS & $\begin{array}{l}\text { Teor de } \\
\text { amido }\end{array}$ \\
\hline ametryne + IAC14 & Pré & 5,6 & 6,6 & 87,7 & 45,7 & 19,6 \\
\hline ametryne $+576-70$ & Pré & 6,2 & 3,8 & 90,1 & 41,7 & 18,4 \\
\hline clomazone+ IAC14 & Pré & 6,2 & 4,4 & 89,4 & 48,2 & 21,8 \\
\hline clomazone+ IAC576-70 & Pré & 5,6 & 5,2 & 89,2 & 36,4 & 16,3 \\
\hline ametryne + clomazone + IAC14 & Pré & 4,3 & 1,2 & 94,4 & 26,1 & 18,4 \\
\hline ametryne + clomazone + IAC576-70 & Pré & 3,9 & 1,6 & 94,5 & 32,8 & 17,0 \\
\hline atrazine + IAC14 & Pré & 4,7 & 3,0 & 92,3 & 42,8 & 21,0 \\
\hline atrazine + IAC576-70 & Pré & 5,1 & 6,6 & 88,3 & 42,3 & 19,7 \\
\hline haloxyfof-methyl + IAC14 & Pós & 5,6 & 2,7 & 91,7 & 54,7 & 23,0 \\
\hline haloxyfof-methyl + IAC576-70 & Pós & 6,3 & 6,0 & 87,7 & 54,4 & 18,2 \\
\hline sethoxidim + IACIAC14 & Pós & 6,8 & 5,7 & 87,4 & 53,9 & 22,1 \\
\hline sethoxidim + IAC576-70 & Pós & 5,4 & 2,9 & 91,6 & 34,5 & 19,9 \\
\hline fluazifop-P-butil + IAC14 & Pós & 5,0 & 5,0 & 89,9 & 45,4 & 21,4 \\
\hline fluazifop-P-butil + IAC576-70 & Pós & 5,8 & 5,5 & 88,6 & 33,8 & 20,6 \\
\hline quizalofop-P-ethyl + IAC14 & Pós & 3,9 & 3,1 & 93,0 & 38,9 & 20,6 \\
\hline quizalofop-P-ethyl + IAC576-70 & Pós & 5,9 & 3,3 & 90,7 & 38,3 & 22,8 \\
\hline fomezafen + IAC14 & Pós & 16,8 & 4,0 & 79,2 & 43,5 & 21,8 \\
\hline fomezafen + IAC576-70 & Pós & 4,4 & 3,8 & 91,8 & 37,4 & 20,3 \\
\hline bentazon + IAC14 & Pós & 3,7 & 5,4 & 91,0 & 37,6 & 17,5 \\
\hline bentazon + IAC576-70 & Pós & 5,3 & 5,4 & 89,4 & 38,4 & 24,6 \\
\hline testemunha capinada + IAC14 & --- & 5,5 & 3,2 & 91,3 & 48,4 & 20,0 \\
\hline testemunha capinada + IAC576-70 & --- & 5,2 & 2,2 & 92,6 & 45,8 & 18,5 \\
\hline
\end{tabular}

Pré- Aplicados em pré-emergência

Pós-Aplicados em pós-emergência

Na Tabela 39, verifica-se no experimento realizado na Fazenda Experimental Lageado que os herbicidas não afetaram o balanço de massa, sendo que alguns tratamentos produziram maior percentual de raiz, parâmetro importante para indústria e consumo in natura, os tratamentos não distanciaram das porcentagens da testemunha capina. No entanto quando aplicada ametryne na variedade IAC14 percebe-se maiores percentuais de casca e ponta fibrosa o mesmo não ocorre com a mesma molécula aplicada na variedade IAC576-70. 
Na mesma Tabela 39, registram-se os teores de amido dos tratamentos, porém não ocorre distanciamento das testemunhas sem aplicação de herbicidas, sendo que os maiores teores de amido foram verificados na aplicação de clomazone+ IAC576-70 e ametryne + clomazone + IAC14. Os teores de amido encontrados são os mesmos que as indústrias conseguem extrair.

Tabela 39. Balanço de massa das raízes de mandioca nas variedades IAC14 e IAC576-70 na Fazenda Experimental Lageado em Botucatu-SP, 2009.

\begin{tabular}{|c|c|c|c|c|c|c|}
\hline TRATAMENTOS & $\begin{array}{c}\text { Modo de } \\
\text { aplicação }\end{array}$ & Casca & Ponta & $\begin{array}{r}\text { Polpa } \\
\% \\
\end{array}$ & MS & $\begin{array}{l}\text { Teor de } \\
\text { amido }\end{array}$ \\
\hline ametryne + IAC14 & Pré & 5,6 & 8,6 & 85,8 & 39,8 & 19,4 \\
\hline ametryne + IAC576-70 & Pré & 3,0 & 4,1 & 92,9 & 48,4 & 21,1 \\
\hline clomazone+ IAC14 & Pré & 2,8 & 4,1 & 93,1 & 52,2 & 21,3 \\
\hline clomazone+ IAC576-70 & Pré & 2,9 & 5,7 & 91,4 & 38,9 & 24,7 \\
\hline ametryne + clomazone + IAC14 & Pré & 2,8 & 5,8 & 91,4 & 41,8 & 24,6 \\
\hline ametryne + clomazone + IAC576-70 & Pré & 4,7 & 7,9 & 87,5 & 44,1 & 19,5 \\
\hline atrazine + IAC14 & Pré & 3,4 & 5,4 & 91,3 & 40,7 & 22,7 \\
\hline atrazine + IAC576-70 & Pré & 3,0 & 5,9 & 91,1 & 38,2 & 22,7 \\
\hline haloxyfof-methyl + IAC14 & Pós & 3,5 & 5,3 & 91,2 & 43,5 & 23,9 \\
\hline haloxyfof-methyl + IAC576-70 & Pós & 2,2 & 4,3 & 93,4 & 39,9 & 21,4 \\
\hline sethoxidim + IACIAC14 & Pós & 2,5 & 6,3 & 91,2 & 41,3 & 24,9 \\
\hline sethoxidim + IAC576-70 & Pós & 2,8 & 4,9 & 92,3 & 41,4 & 20,9 \\
\hline fluazifop-P-butil + IAC14 & Pós & 2,8 & 7,8 & 89,4 & 47,2 & 22,9 \\
\hline fluazifop-P-butil + IAC576-70 & Pós & 2,6 & 6,3 & 91,2 & 41,7 & 16,9 \\
\hline quizalofop-P-ethyl + IAC14 & Pós & 4,1 & 7,6 & 88,3 & 43,2 & 20,6 \\
\hline quizalofop-P-ethyl + IAC576-70 & Pós & 3,1 & 6,4 & 90,5 & 42,9 & 19,6 \\
\hline fomezafen + IAC14 & Pós & 5,3 & 8,6 & 86,1 & 41,6 & 18,8 \\
\hline fomezafen + IAC576-70 & Pós & 3,0 & 6,6 & 90,4 & 38,8 & 20,0 \\
\hline bentazon + IAC14 & Pós & 2,2 & 4,1 & 93,7 & 43,5 & 18,2 \\
\hline bentazon + IAC576-70 & Pós & 3,6 & 5,1 & 91,3 & 43,8 & 21,7 \\
\hline testemunha capinada + IAC14 & ---- & 2,5 & 5,4 & 92,1 & 41,6 & 23,6 \\
\hline testemunha capinada + IAC576-70 & --- & 2,7 & 5,5 & 91,8 & 43,6 & 20,8 \\
\hline
\end{tabular}

Pré- Aplicados em pré-emergência

Pós-Aplicados em pós-emergência

Não se tem relatos de trabalhos nos quais os autores busquem verificar essa influencia nos teores de amido, menos ainda que verifiquem residual de herbicidas no amido da mandioca. $\mathrm{O}$ mesmo acontece para o balanço de massa, onde os trabalhos encontrados, com raras 
exceções, avaliaram a seletividade sem acompanhar o ciclo da cultura e os parâmetros finais da colheita, fato esse que dificulta a discussão e comparação com outros trabalhos. 


\section{CONSIDERAÇÕES FINAIS}

Em ambos os experimentos as moléculas fomezafen e bentazon aplicadas em pós-emergência da cultura, causaram injúrias severas nas variedades estudadas, embora não tenham levado a morte de uma única planta de mandioca. As moléculas ametryne, ametryne + clomazone e clomazone aplicadas em pré-emergência foram as que ocasionaram menores injurias, que foram consideradas leves ou de pouca importância.

No ensaio realizado na Fazenda Experimental São Manuel não foram observados efeitos significativos das moléculas testadas, independente da variedade, nos seguintes parâmetros: altura das plantas, altura da primeira ramificação, número de plantas por hectare, produção de cepas por hectare, produção de massa seca de cepa por hectare, diâmetro da raiz, comprimento da raiz, produtividade das raízes, produtividade de massa seca das raízes e índice de colheita e efeitos significativos das moléculas testadas, independente da variedade, na produção da parte aérea por hectare e produção de massa seca da parte aérea, onde a molécula bentazon ocasionou significativa redução, em relação a mistura das moléculas ametryna e clomazone.

No ensaio realizado na Fazenda Experimental Lageado não foram verificados efeitos significativos das moléculas testadas, independente da variedade, nos seguintes parâmetros: diâmetro das raízes, comprimento das raízes, produção de massa seca das cepas por hectare e índice de colheita. No entanto os houve efeito significativo das moléculas testadas, nos parâmetros: altura das plantas, onde a molécula bentazon, independente da variedade promoveu 
significativa redução na altura das plantas, em relação à molécula clomazone e a mistura ametryne e clomazone. A molécula haloxifop - methyl promoveu redução da altura da primeira ramificação em relação à molécula clomazone. Quando observado o número de plantas por hectare a testemunha capinada tem menor número de plantas em relação à molécula clomazone.

A produção da parte aérea por hectare foi afetada pelas moléculas haloxifop - methyl e bentazon, em relação à molécula clomazone, observam-se redução desse parâmetro. Quando observado a produção de massa seca da parte aérea a molécula haloxifop - methyl ocasiona redução em relação a molécula clomazone. No entanto, quando observada a produção de cepas por hectare percebe-se que as moléculas quizalofop-p-ethyl e fomezafen promoveu redução em relação a molécula clomazone.

A produtividade das raízes foi afetada pela aplicação da molécula fomezafen em relação à molécula clomazone. Quando observada a produtividade de massa seca das raízes as moléculas haloxifop - methyl, fomezafen e bentazon ocasionaram redução em relação à molécula clomazone.

A molécula clomazone independente da variedade a qual foi aplicada foi a que menos danos causou aos parâmetros estudados no ensaio da Fazenda Experimental Lageado em Botucatu-SP e as moléculas fomezafen, bentazon e haloxifop - methyl as que causaram maiores reduções dos mesmos parâmetros.

A variedade IAC14 independente da molécula de herbicida aplicada tem melhor desempenho nos parâmetros avaliados em ambos os experimentos.

A molécula fomezafen aplicada na variedade IAC14 proporcionou maior porcentagem de casca, o restante dos tratamentos não afetou o balanço de massa das variedades em ambos os tipos de solo.

O teor de amido não foi afetado em ambas as variedades e ambientes estudados 


\section{CONCLUSÃO}

As moléculas de herbicidas estudadas são seletivas, em graus distintos, às variedades de mandioca avaliadas. 


\section{REFERÊNCIAS BIBLIOGRAFICAS}

AGUIAR, E. B. Produção e qualidade de mandioca de mesa (Manihot esculenta Crantz) em diferentes densidades populacionais e épocas de colheita. 2003.90 p. Dissertação (Mestrado em. Mestrado Agricultura Tropical e Subtropical..)-Instituto Agronômico de Campinas, Campinas, 2003.

ALCÂNTARA, E. N.; LIMA, P. C. Efeito de doses de herbicida para a cultura da mandioca (Manihot esculenta Crantz). In: EMPRESA DE PESQUISA AGROPECUÁRIA DE MINAS GERAIS. Projeto Mandioca, relatório 76/79. Belo Horizonte, 1982. p. 130-135.

ALCÂNTARA, E. N.; SOUZA, I. F. Herbicidas na cultura da mandioca. In: EMPRESA DE PESQUISA AGROPECUÁRIA DE MINAS GERAIS. Projeto mandioca, relatório 76/79. Belo Horizonte, 1982. p. 136-141.

ALONSO, D. G. et al. Avaliação da eficácia e viabilidade de trifluralina nortox gold na cultura da mandioca. Revista Raízes e Amidos Tropicais, Botucatu, v. 3, 2007 a.

ALONSO, D. G. et al. Controle de plantas daninhas com alaclor nortox aplicado em pré-emergência na cultura da mandioca. Revista Raízes e Amidos Tropicais, Botucatu, v. 3, 2007b.

ANDRADE, C. A. B. Efeitos de espaçamentos, idades de colheita e anos de plantio sobre algumas características de duas cultivares de mandioca (Manihot esculenta, Crantz). 1989. 63 p. Dissertação (Mestrado em Fitotecnia)-Escola Superior de Agricultura de Lavras, Lavras, 1989. 
ARANTES, J. G. Z. et al. Seletividade de diferentes alternativas de herbicidas para a cultura da mandioca: variedade fécula branca. Revista Raízes e Amidos Tropicais, Botucatu, v. 3, 2007.

BIFFE, D. F. et al. Avaliação do herbicida diuron em pré-emergência no controle de seis plantas daninhas na cultura de Manihot esculenta. Revista Raízes e Amidos Tropicais, Botucatu, v. 3, 2007.

BRASIL. Ministério da Agricultura, Pecuária e Abastecimento. Disponível em:

$<$ http://www.agricultura.gov.br/>. Acesso em: 29 dez. 2009.

CARVALHO, J. E. B. de; REZENDE, G. de O.; SOUZA, J. da S. Estudo econômico de métodos integrados de controle de plantas daninhas na cultura da mandioca em fileiras simples e duplas.

Revista Brasileira de Mandioca, Cruz das Almas, v. 9, n. 1/2, p. 51-59, 1990.

COMPANHIA DE ENTREPOSTOS E ARMAZÉNS GERAIS DO ESTADO DE SÃO PAULO. Preços praticados no CEAGESP. São Paulo, 2008. Disponível em:

<http://www.ceagesp.gov.br/cotação>. Acesso em: 25 abr. 2008.

CUNHA, A. R.; MARTINS, D. Classificação climática para os municípios de Botucatu e São Manuel, SP. Irriga, Botucatu, v. 14, n. 1, p. 1 - 11, 2009.

DEUBER, R. Ciência das plantas daninhas: manejo. Campinas: O Autor, 1997. v. 2, 284 p.

EMPRESA BRASILEIRA DE PESQUISA AGROPECUÁRIA. Centro Nacional de Pesquisa de Solos. Sistema brasileiro de classificação de solos. Brasília, DF: EMBRAPA Produção de Informação; Rio de Janeiro: EMBRAPA Solos, 1999. 412p.

ENYI, B. A. C. Growth rates of three cassava varieties (Manihot esculenta Crantz) under varying population densities. Journal of Agricultural Science, Cambridge, v. 81, p. 15-28, 1973.

FUKUDA, W. M. G.; CALDAS, R. C. Influência da época de colheita sobre o comportamento de cultivares e clones de mandioca. Revista Brasileira de Mandioca, Cruz das Almas, v. 4, n. 2, p. 37 44, 1985.

HAMMER, G. L.; HOBMAN, F. R.; SHEPHERD, R. K. Effects of planting time and harvest age on cassava (Manihot esculenta) in Northern Australia. I. Crop growth and yield in moist environments. Experimental Agriculture, Cambridge, v. 23, n. 4, p. 401-414, 1987. 
HOBMAN, F. R.; HAMMER, G. L.; SHEPHERD, R. K. Effects of planting time and harvest age on cassava (Manihot esculenta) in Northern Australia. II. Crop growth and yield in a seasonally-dry environment. Experimental Agriculture, Cambridge, v. 23, n. 4, p. 415- 424, 1987.

KAWANO, K. Mejoramiento genetico de yuca para productividad. In: DOMÍNGUEZ, C. E. (Ed.) Yuca: investigación, producción y utilización. Cali: PNUD \& CIAT, 1982. p. 91-112.

LEONEL-NETO, M. Influência da idade de colheita e espaçamento sobre algumas características de duas cultivares de mandioca (Manihot esculenta, Crantz). 1983. $57 \mathrm{f}$. Dissertação (Mestrado em Fitotecnia)- Escola Superior de Agricultura de Lavras, Lavras, 1983.

LORENZI, H. Manual de identificação e plantas daninhas: plantio direto e convencional. 6. ed. Nova Odessa: Instituto Plantarum, 2006. 339 p.

LORENZI, J. O. et al. Raízes e tubérculos. Boletim Técnico do Instituto Agronômico de Campinas, Campinas, n. 100, p. 221-229, 1996.

LORENZI, J. O. et al. Variedade de mandioca de mesa IAC 576-70. Campinas: CATI, 1984. 4 p. (Comunicado técnico, n. 80).

LORENZI, J. O. Mandioca. Campinas: CATI, 2003. 110 p. (Boletim técnico, n. 245).

LUTMAN, P. J. W. Weeds in potatoes. In: HARRIS, P. M. The potatoes crop: the scientific basis for improvement. 2nd ed. London: Chapman \& Hall, 1992. p. 373-379.

MASCARENHAS, M. H. T. Incidência e controle de plantas daninhas em áreas irrigadas. Informe Agropecuário, Belo horizonte, v. 13, n. 152, p. 33, 1988.

MIRANDA, I. J.; LAVINA, M. L.; POA, A. C. Controle de plantas daninhas na cultura da mandioca através de herbicidas pré-emergentes pós plantio em podzólico vermelho amarelo distrófico. In: CONGRESSO BRASILEIRO DE HERBICIDAS E PLANTAS DANINHAS, 20., 1995, Florianópolis. Resumos... Florianópolis: SBCPD, 1995. p. 138-139.

MONTALDO, A. La yuca. San Jose: IICA, 1979. 386 p. 
OLIVEIRA JUNIOR, R. S. et al. Manejo químico de plantas daninhas em área de plantio direto de mandioca. Revista Brasileira de Herbicidas, Passo Fundo, v. 2, n. 3, p. 99-106, 2001 a.

OLIVEIRA JUNIOR, R. S. et al. Tolerância de cinco cultivares de mandioca (Manihot esculenta) a herbicidas. Planta Daninha, Viçosa, v. 19, n. 1, p. 119-125, 2001 b.

OLIVEIRA JUNIOR, R. S. Seletividade e eficiência de trifluralin e diuron aplicados em diferentes formas na cultura da mandioca (Manihot esculenta Crantz). Revista Unimar, Maringá, v. 16, n. 2, p. $317-325,1994$ c.

PERESSIN, V. A. Matointerferência na cultura da mandioca (Manihot esculenta Crantz) em duas regiões do estado de São Paulo. 1997. 132 p. Tese (Doutorado em Agronomia)-Faculdade de Ciências Agronômicas e Veterinária, Universidade Estadual Paulista, Jaboticabal, 1997.

PINHO, J. L. N. et al. Controle de plantas daninhas na cultura da mandioca (Manihot esculenta Crantz), no Ceará. In: EMPRESA DE PESQUISA AGROPECUÁRIA DO CEARÁ. Relatório anual de pesquisa da EPACE. Fortaleza, 1980. p. 53-81.

PITELLI, R. A. Ervas daninhas x culturas anuais. A Granja, Porto Alegre, v. 36, n. 387, p. 56-61, 1980.

RAJCAN, I.; SWANTON, C. J. Understanding maize-weed competition: resource competition, light quality and the whole plant. Field Crops Research, Amsterdam, v. 71, n. 2, p. 139-150, 2001.

SILVA, F. M. L. et al. Moléculas de herbicidas seletivas a cultura da mandioca. Revista Trópica, Chapadinha, v. 3, n. 2, p. 61-72, 2009.

SOCIEDADE BRASILEIRA DA CIÊNCIA DAS PLANTAS DANINHAS. Procedimentos para instalação, avaliação e análise de experimentos com herbicidas. Londrina: 1995. 42 p.

TERRA, M. A. Seletividade de diclosulam, trifloxysulfuron-sodium e ametryne a variedades de cana-de-açúcar. 2003. 60 f. Dissertação (Mestrado em Agronomia/Agricultura)-Faculdade de Ciências Agronômicas, Universidade Estadual Paulista, Botucatu, 2003.

VELINI, E. D. et al. Avaliação da seletividade da mistura de oxyfluorfen e ametryne, aplicada em pré ou pós-emergência, a dez variedades de cana-de-açúcar (cana-planta). Planta Daninha, Londrina, v. 18, n. 1, p. 123-134, 2000. 
WILLIAMS, C. N. Growth and productivity of tapioca (Manihot utilissima): IV. development and yield of tubers. Experimental Agriculture, Great Britain, v. 10, p. 9-16, 1974.

WILLIAMS, C. N. Growth and productivity of tapioca (Manihot utilissima): III. crop ratio, spacing and yelding. Experimental Agriculture, Great Britain, v. 8, p. 15-23, 1972. 